\title{
Marine Benthic Plants of Western Australia's Shelf-Edge Atolls
}

\author{
John M. Huisman ${ }^{1,2}$, Frederik Leliaert ${ }^{3}$, Heroen Verbruggen ${ }^{3}$ and Roberta A. Townsend ${ }^{1}$ \\ ${ }^{1}$ School of Biological Sciences and Biotechnology, Murdoch University, Murdoch, W.A. 6150 \\ ${ }^{2}$ Western Australian Herbarium, Department of Environment and Conservation, Kensington, W.A. 6151 \\ ${ }^{3}$ Phycology Research Group and Centre for Molecular Phylogenetics and Evolution, Biology Department, Ghent \\ University, Krijgslaan 281 (S8), 9000 Ghent, Belgium.
}

\begin{abstract}
One hundred and twenty-one species of marine algae, seagrasses and cyanobacteria are reported from the offshore atolls of northwestern Western Australia (the Rowley Shoals, Scott Reef and Seringapatam Reef). Included are 65 species of Rhodophyta, 40 species of Chlorophyta, nine species of Phaeophyceae, three species of Cyanophyta and four species of seagrasses. This report presents the first detailed account of marine benthic algae from these atolls. Twenty-four species are newly recorded for Western Australia, with four species (Anadyomene wrightii, Rhipilia nigrescens, Ceramium krameri and Zellera tawallina) also newly recorded for Australia.
\end{abstract}

Key words: Algae; Australia; Biogeography; Systematics

\section{INTRODUCTION}

The Rowley Shoals, Scott Reef and Seringapatam Reef are shelf edge atolls lying some $300 \mathrm{~km}$ off the coast of northwestern Australia, on the continental slope in clear oceanic waters. Prior to an unpublished survey undertaken by the first author for environmental consultants URS (in February, 2006), records of macroalgae from these reefs were extremely limited, as is generally true for much of north-western Australia. Several expeditions collecting biological samples have visited the reefs, but none have made a concerted effort to collect the marine algae. A Russian expedition in 1978 resulted in the description of a new genus and species of coralline red algae, Rhizolamellia collum Shevejko (Shevejko, 1982), but the distinctiveness of this taxon was questioned by Woelkerling (1988) and it requires further study. No further records of algae were published from the Russian expedition. Skewes et al., (1999) conducted visual surveys and gave a list of taxa for Scott and Seringapatam Reefs, mostly identified to genus only. They recorded 11 taxa or growth forms, presented here in Table 1 along with the reported percent cover.

These results give an indication of the ecological significance of macroalgae for the reefs, but as no voucher specimens were collected there would appear to be no way to confirm the taxon identifications.

Other than the new genus described by Shevejko (1982) and the list presented by Skewes et al., (1999), there are no published accounts of macroalgae from the Rowley Shoals and Scott and Seringapatam Reefs. Moreover, prior to the present additions, no specimens were lodged in the Western Australian State Herbarium (search undertaken October 2006), the official repository of the State's plant collections. On a broader scale, a 1995 survey of the marine biota of the northern Kimberley (Walker et al., 1996) was undertaken, but did not include the offshore atolls. The macroalgal component of that survey included 90 species, most of which were widespread tropical taxa. Walker (1996, p. 38) commented that the diversity and abundance of the algal flora was generally poor' in the northern Kimberley.

Walker \& Prince (1987) recorded three species of seagrass in their collections from Scott Reef and the Rowley Shoals: Thalassia hemprichii, Halophila ovalis and Thalassodendron ciliatum. The first two are common at the atolls and were re-collected during the recent surveys that provided the specimens documented in the present paper, along with a third species, Halophila decipiens. Thalassodendron ciliatum, however, was not observed. Walker \& Prince (1987), in what was the first record for Western Australia, note that it usually grows attached to rock or course grit, in areas of high currents.

On a larger geographical scale, the macroalgal flora of north-western Australia is poorly known, but is the subject of intensive and ongoing studies. 
Table 1 Macroalgae and percent cover recorded from Scott and Seringapatam Reefs by Skewes et al., (1999).

\begin{tabular}{l|l|l|l}
\hline \multirow{2}{*}{ Taxon/ Growth form } & \multicolumn{2}{|l|}{ Scott Reef \% cover } & Seringapatam Reef \% cover \\
\cline { 2 - 4 } & South & North & \\
\hline Halimeda spp. & 3.15 & 1.26 & 1.02 \\
Dictyota spp. & 0.00 & 0.20 & 0.43 \\
Turbinaria ornata & 0.11 & 0.46 & 0.07 \\
Caulerpa spp. & 0.15 & 0.87 & 4.63 \\
Ceratodictyon spp. & 0.63 & 0.57 & 1.12 \\
Gracilaria spp. & 0.83 & 0.07 & 0.00 \\
Laurencia spp. & 0.68 & 0.02 & 0.00 \\
Turf Algae & 7.88 & 10.89 & 8.12 \\
Padina spp. & 0.01 & 0.10 & 0.00 \\
Crustose coralline & 1.14 & 3.06 & 1.10 \\
Cladophora socialis & 2.96 & 3.64 & 6.56 \\
\hline Total Algal Cover & $\mathbf{1 9 . 7 6}$ & $\mathbf{2 2 . 3 8}$ & $\mathbf{2 3 . 0 5}$ \\
\hline
\end{tabular}

The first author of the present chapter is presently compiling a marine flora for the region, funded in-part by the 'Australian Biological Resources Study'. Thus, while published records are scant, the author's unpublished knowledge of the marine flora is considerable and has been incorporated to a degree in the present account.

The aims of the present survey were to assess the species composition and distribution of macroalgal and seagrass species occurring at the Rowley Shoals, Scott and Seringapatam Reefs.

\section{METHODS}

The present publication is based on collections made by the first author on three separate field surveys. The first was undertaken in February 2006 by environmental consultants URS on behalf of Woodside Energy. This trip visited Scott Reef

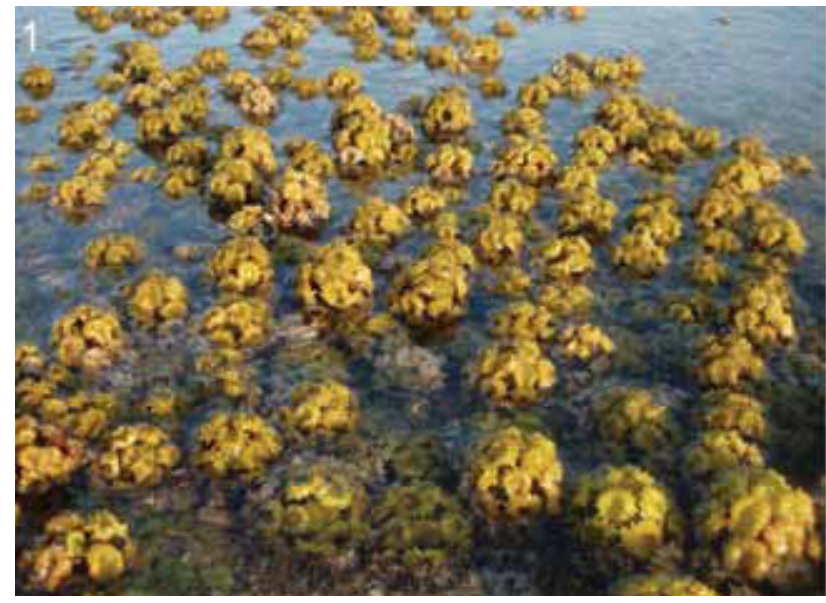

Figure 1 Turbinaria ornata, dense cover at Seringapatam Reef. and Seringapatam Reef. The second, in September 2006, was by the Western Australian Museum (W A Museum) with funding support from Woodside Energy. This survey also visited those reefs but in addition included Mermaid Reef, the northernmost atoll of the Rowley Shoals. The third trip (December 2007) was a survey of the three atolls of the Rowley Shoals (Imperieuse, Clerke and Mermaid Reefs) undertaken jointly by the Western Australian Department of Environment and Conservation (DEC) and the Australian Institute of Marine Science (AIMS). These surveys yielded a large number of specimens that have been lodged in the Western Australian State Herbarium (PERTH).

During each survey, the algal flora was assessed visually and by specimen collection, either by SCUBA, snorkelling or reef walking. SCUBA diving was only undertaken during the September 2006 and December 2007 surveys. Sampling

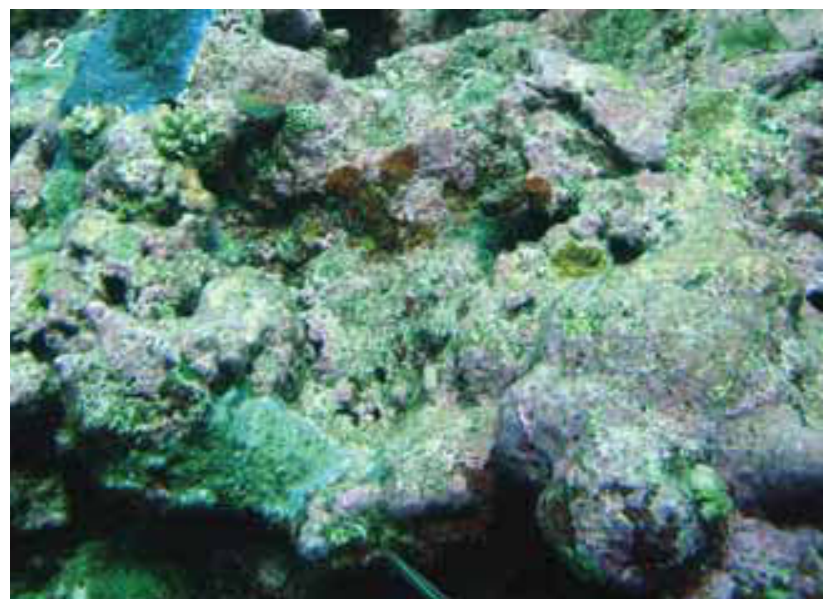

Figure 2. Hydrolithon onkodes, typical of high energy reef crests. 
Table 2 Collection Data for URS Survey, February, 2006 (URS Transect (Tr.) in text). Only including sites mentioned in text.

\begin{tabular}{|c|c|c|c|c|c|c|}
\hline Date & Site & Transect (Tr.) & \multicolumn{2}{|c|}{ Lat } & \multicolumn{2}{|c|}{ Long } \\
\hline 16-Feb-06 & South Scott: East side West Hook, reef walk & 2 & 14 & 4.738 & 121 & 44.869 \\
\hline 18-Feb-06 & $\begin{array}{l}\text { South Scott: Outer reef flat edge in to reef flat, } \\
\text { snorkel }\end{array}$ & 12 & 14 & 10.733 & 121 & 54.068 \\
\hline 19-Feb-06 & $\begin{array}{l}\text { South Scott: Outer reef edge into lagoon, } \\
\text { snorkel }\end{array}$ & 17 & 14 & 7.300 & 121 & 58.250 \\
\hline 19-Feb-06 & $\begin{array}{l}\text { South Scott: Northern east horn, across the } \\
\text { island reef flat, snorkel }\end{array}$ & 21 & 14 & 3.290 & 121 & 57.622 \\
\hline 20-Feb-06 & North Scott: Reef flat -east, snorkel & 23 & 14 & 1.383 & 121 & 51.539 \\
\hline 21-Feb-06 & North Scott: NE channel, snorkel & 27 & 13 & 54.996 & 121 & 54.538 \\
\hline 21-Feb-06 & $\begin{array}{l}\text { North Scott: Snorkel transect of reef flat, } \\
\text { snorkel }\end{array}$ & 28 & 13 & 55.495 & 121 & 54.936 \\
\hline 22-Feb-06 & Seringapatam: Southside of channel, reef walk & 32 & 13 & 38.394 & 122 & 1.409 \\
\hline 22-Feb-06 & Seringapatam: South-east reef flat, Snorkel & 35 & 13 & 40.584 & 122 & 3.146 \\
\hline
\end{tabular}

effort during the latter was somewhat hampered by the majority of the dive time being required to undertake benthic monitoring $(5 \times 50 \mathrm{~m}$ transects), thus regular collecting was limited. During the September 2006 survey, depending on the topography, sites were sampled by: (1) a roughly linear transect from $20 \mathrm{~m}$ depth (where available) towards the shallows (outer reef and some lagoon bommies); (2) transects across the reef flat, perpendicular to the reef crest (reef flats and shallows). Initial attempts to assess percent cover by random photo quadrats proved futile, as the algae were mostly too sparsely distributed. The number of quadrats required to gain even a reasonable assessment of the diversity and cover would have been very large and therefore an inefficient use of limited dive times. At locations where individual species were present in large numbers, a gross assessment of maximum cover was made.

Macroalgae and seagrasses were assessed at all stations visited during the WA Museum survey and station details are provided in the Station and Transect Data section (this volume). Presence/absence data for the macroalgae and seagrasses were incorporated into the overall station comparisons.

Representative specimens were collected from each location and preserved in 5\% Formalin/ seawater (2006 surveys) or pressed directly on herbarium sheets on-site (2007). These specimens have been lodged in the State Herbarium (PERTH). Additional material was also preserved in 100\% Etoh (green algae) or dried in silica gel (red algae) for DNA analysis. Locations visited during the URS 2006 survey are listed in Table 2. Table 5 gives the presence of individual taxa at each location observed during the WA Museum survey of 2006.

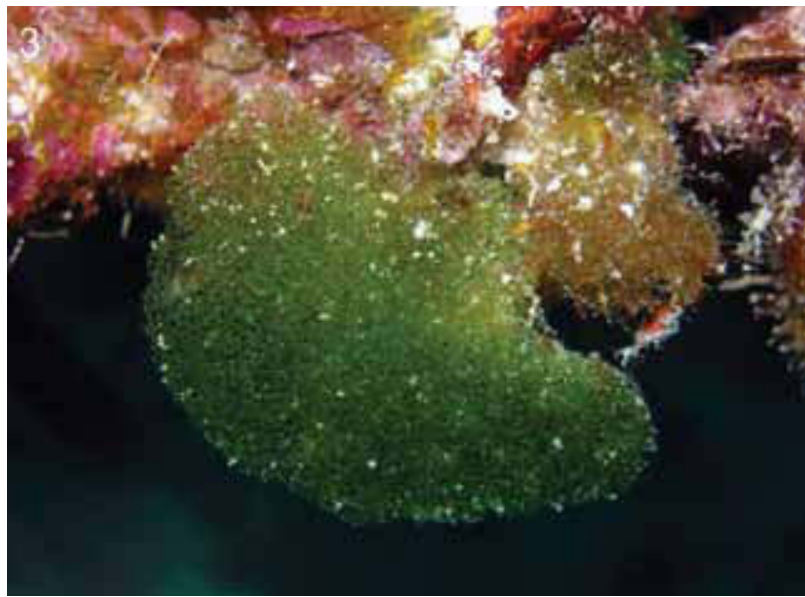

Figure 3 Rhipilia nigrescens, a spongy green alga found in reef front habitats.

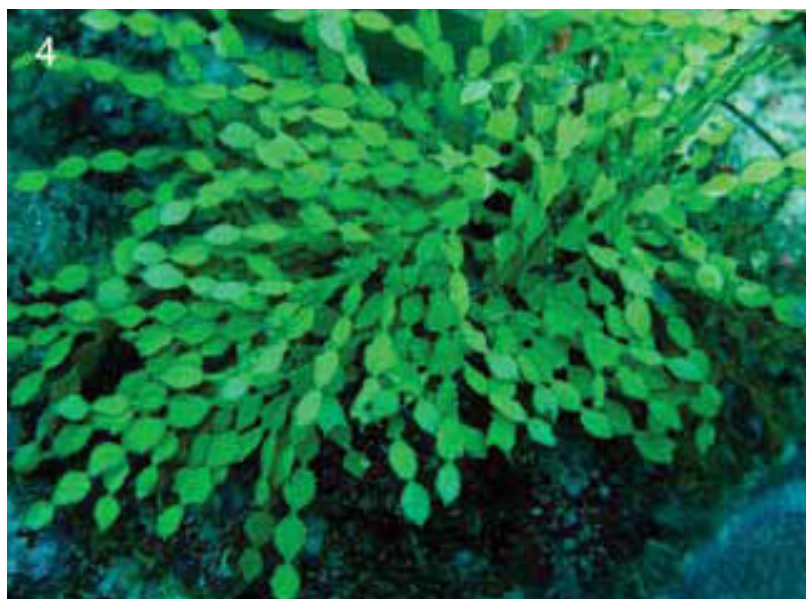

Figure 4 Halimeda minima, common in shaded areas in most habitats. 


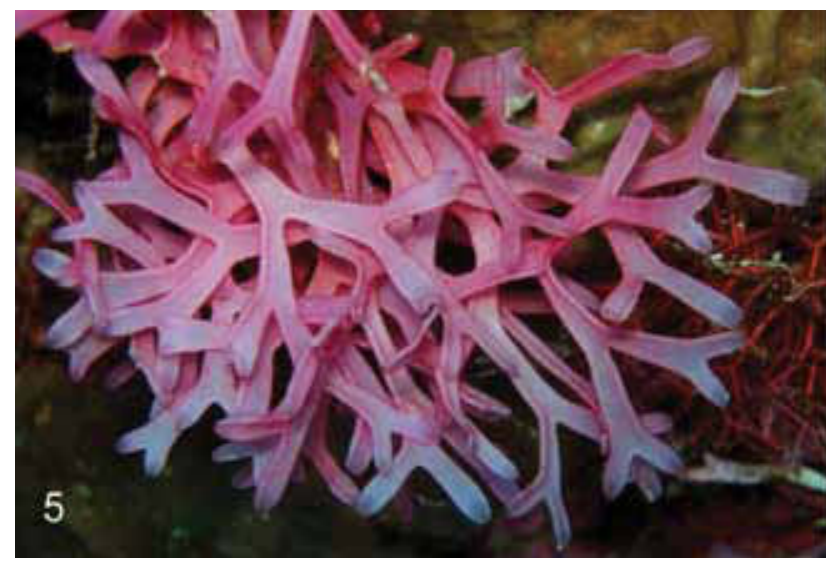

Figure 5 Dichotomaria marginata, generally in reef front habitats.

\section{RESULTS}

A systematic list of taxa observed and/or collected during the three surveys is presented below. Table 5, however, includes only those species recorded during the WA Museum survey of 2006 and is included here to enable combined analyses with the fauna. The taxa observed and/or collected at each station are listed in Table 5.

General algal cover was estimated at only approximately $5-10 \%$, but was extremely variable with some areas approaching $100 \%$ cover (e.g. Turbinaria ornata on the reef flat at Seringapatam, figure 1). The overall diversity of marine algae at the reefs visited is low, with only a small number of conspicuous species recorded. Several of these are consistently present in certain habitats:

Reef front - Crustose corallines (primarily Hydrolithon onkodes, figure 2) dominated the shallow reef crest, where they grew over and consolidated dead coral and rubble. In some places crustose corallines covered almost all available hard surfaces, occasionally reaching up to $65 \%$ cover. These areas were typically more exposed to wave action and the non-coralline algal species were

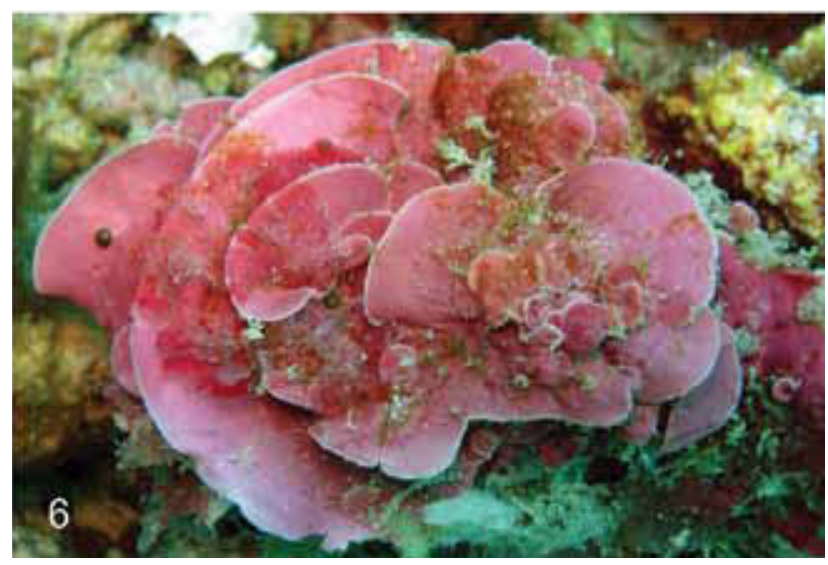

Figure 6 Rhizolamellia collum, restricted to dark crevices on reef fronts

restricted to localized protected microhabitats (on edges of outcrops, in gaps etc.). Non-coralline species observed at the shallow reef crest include Rhipilia nigrescens (Figure 3), Sphacelaria tribuloides, Dictyosphaeria versluysii, and Valonia ventricosa. In deeper water, species of Halimeda (e.g., $H$. minima, figure 4), Galaxaura, Dichotomaria (Figure 5) and Tricleocarpa were occasionally common in exposed areas, but most of the algal diversity was restricted to protected areas under overhangs and within crevices. In these habitats, several crustose corallines (including Rhizolamellia collum, figure 6) and species of Peyssonnelia (Figure 7) were common, more sporadically the red alga Corynocystis prostrata (Figure 8), Zellera tawallina and the gelatinous Gibsmithia hawaiiensis (Figure 9). At one station (16) large stands of Halimeda opuntia were observed at depth.

Reef flats - The brown algae Turbinaria ornata (Figure 1) was present in most situations in the reef flat where hard substrata were available, but only at Seringapatam Reef did it reach high densities. The only other brown alga regularly encountered was the crustose form of Lobophora variegata (Figure

Table 3 Macroalgal species recorded from various localities (partially from Huisman et al., 1998)

\begin{tabular}{l|l|l}
\hline Region/Island & Recorded taxa & Source \\
\hline Philippines & 911 & Silva et al., 1987 \\
Indonesia & 452 & Verheij \& Prud'homme van Reine 1993 \\
Australia, Dampierian province & $>350$ & Huisman, unpublished obs. \\
Dampier Archipelago & 210 & Huisman \& Borowitzka 2003 \\
Lord Howe I., N.S.W. & 298 & Australian Marine Algal Name Index \\
Barrow I. & 170 & Huisman, unpublished obs. \\
Eastern Kimberley & 90 & Walker 1996 \\
Scott \& Seringapatam Reefs & \pm 50 & URS Survey (2006) \\
Rowley Shoals, Scott \& Seringapatam Reefs & \pm 121 & This survey \\
\hline
\end{tabular}


Table 5 Presence of individual taxa (X) at each station observed during the Western Australian Museum Survey of 2006.

TAXA
Mermaid Reef
\begin{tabular}{|c|c|c|c|c|c|c|c|c|c|c|c|c|c|c|c|c}
\hline & \multicolumn{10}{c|}{} \\
\hline & 1 & 2 & 3 & 4 & 5 & 6 & 7 & 8 & 9 & 10 & 11 & 12 & 13 & 14 & 15 & 16 \\
\hline
\end{tabular}

Chlorophyta (Green Algae)

\section{ANADYOMENACEAE}

Anadyomene plicata C.Agardh 1823

Anadyomene wrightii Harvey ex J.E.Gray 1866

Microdictyon okamurae Setchell 1925

Phyllodictyon anastomosans (Harvey)

Kraft \& Wynne 1996

\begin{tabular}{l|l|l|l|l|l|l|l|l|l|l|l|l|l|l|l|l} 
& & $x$ & & $x$ & & & & & & & & $x$ & & $x$ & $x$ \\
\hline & & & & & & & & & & & & $x$ & $x$ & & \\
\hline & & & & & & & & & & & & & & & \\
\hline
\end{tabular}

\section{BRYOPSIDACEAE}

\section{Bryopsis sp. \\ CAULERPACEAE}

Caulerpa cupressoides (Vahl) C.Agardh 1817

Caulerpa serrulata (Forssk.) J.Agardh 1837

Caulerpa taxifolia (Vahl) C.Agardh 1817

Caulerpa webbiana Montagne 1837

Caulerpa verticillata J.Agardh 1847

\section{CHAETOPHORACEAE}

Uronema marinum Womersley 1984

\section{CHAETOSIPHONACEAE}

Blastophysa rhizopus Reinke 1889

\section{CLADOPHORACEAE}

Cladophora herpestica (Montagne) Kützing 1849

\section{CODIACEAE}

Codium arabicum Kützing 1856

Codium dwarkense Børgesen 1947

Codium sp.

\section{DASYCLADACEAE}

Neomeris bilimbata Koster 1937

\section{HALIMEDACEAE}

Halimeda cylindracea Decaisne 1842

Halimeda discoidea? Decaisne 1842

Halimeda macroloba Decaisne 1841

Halimeda macrophysa Askenasy 1888

Halimeda minima (Taylor) Hillis-Colinvaux 1968

Halimeda opuntia(Linnaeus) Lamouroux 1816

\section{SIPHONOCLADACEAE}

Boodlea composita (Harvey) Brand 1904

Boodlea vanbosseae Reinbold 1905

Boergesenia forbesii (Harvey) Feldmann 1938

Cladophora herpestica (Montagne) Howe 1914

Dictyosphaeria cavernosa(Forssk.) Børgesen 1932

Dictyosphaeria versluysii Weber -van Bosse 1905

\section{UDOTEACEAE}

Avrainvillea amadelpha (Montagne)

Gepp \& Gepp 1908

Rhipidosiphon javensis Montagne 1842

Rhipilia crassa Millar \& Kraft 2001

Rhipilia nigrescens Coppejans \& Prud'homme 1990

\begin{tabular}{l|l|l|l|l|l|l|l|l|l|l|l|l|l|l|l|l}
\hline \\
\hline
\end{tabular}

\begin{tabular}{ll|l|l|l|l|l|l|l|l|}
\hline & & & & & & \\
\hline
\end{tabular}




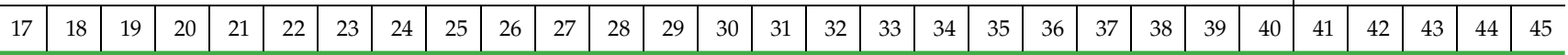

\begin{tabular}{l|l|l|l|l|l|l|l|l|l|l|l|l|l|l|l|l|l|l|l|l|l|l|l|l|l|l|l|l}
\hline $\mathrm{x}$ & $\mathrm{x}$ & $\mathrm{x}$ & $\mathrm{x}$ & $\mathrm{x}$ & & & & $\mathrm{x}$ & $\mathrm{x}$ & & & & & $\mathrm{x}$ & & $\mathrm{x}$ & $\mathrm{x}$ & & $\mathrm{x}$ & & $\mathrm{x}$ & $\mathrm{x}$ & $\mathrm{x}$ & $\mathrm{x}$ & & & & $\mathrm{x}$ \\
\hline & & & & & & & & & & & & & & & & & & & & & & & & & & & & \\
\hline & & & & & & & & & & & & & & $\mathrm{x}$ & & & & & & & & & & & & & & \\
\hline & & & & & & & & & & & & & & & & & & & & & $\mathrm{x}$ & & & & & & \\
\hline
\end{tabular}

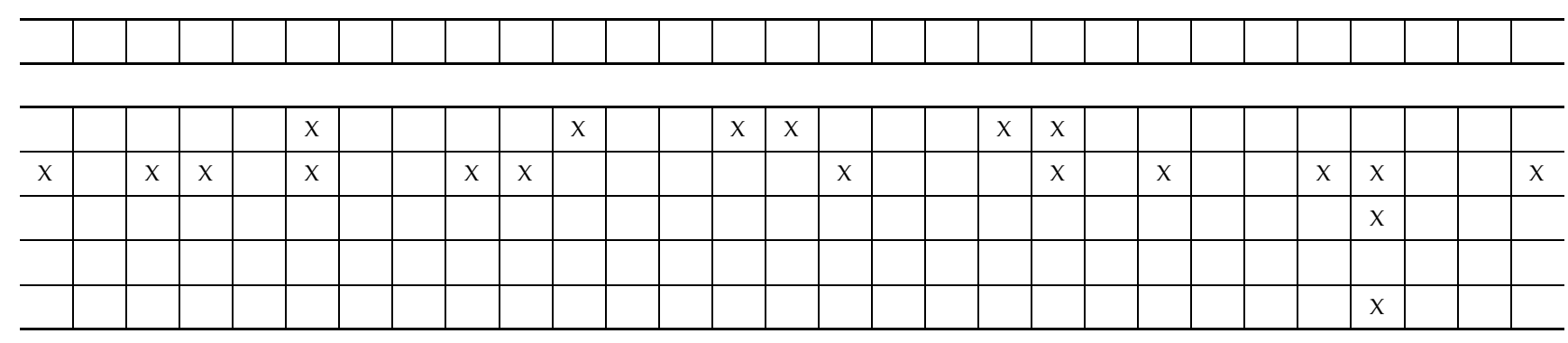
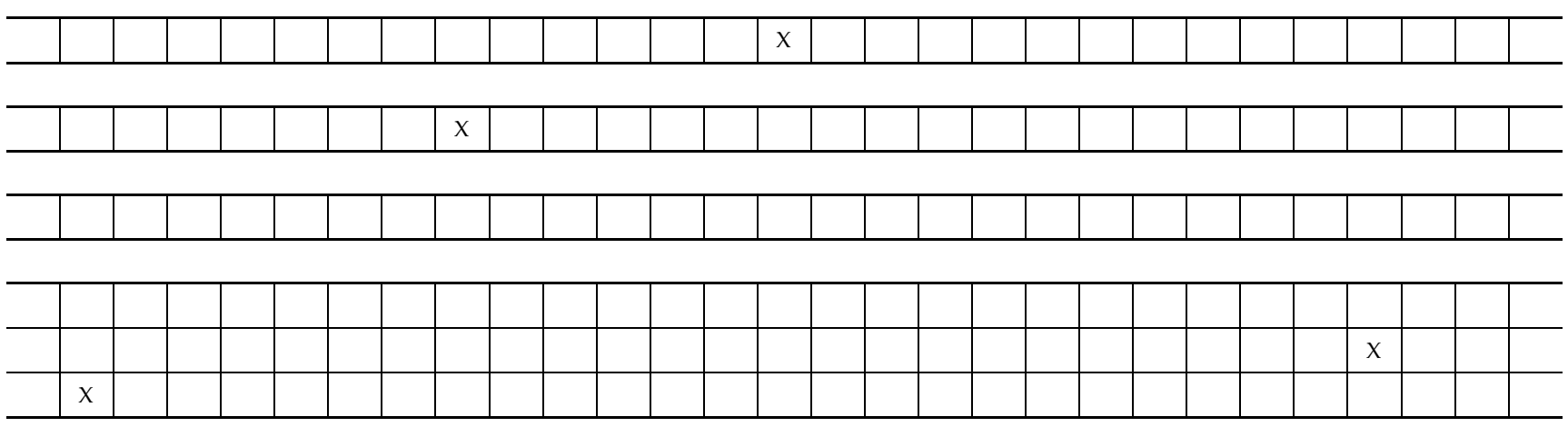

\begin{tabular}{l|l|l|l|l|l|l|l|l|l|l|l|l|l|l|l|l|l|l|l|l|l|l|l|l|l|l|l|l}
\hline & & $\mathrm{x}$ & $\mathrm{x}$ & & $\mathrm{x}$ & $\mathrm{x}$ & & $\mathrm{x}$ & $\mathrm{x}$ & $\mathrm{x}$ & $\mathrm{x}$ & & $\mathrm{x}$ & $\mathrm{x}$ & & $\mathrm{x}$ & $\mathrm{x}$ & $\mathrm{x}$ & $\mathrm{x}$ & $\mathrm{x}$ & $\mathrm{x}$ & $\mathrm{x}$ & & & $\mathrm{x}$ & & $\mathrm{x}$ & $\mathrm{x}$ \\
\hline
\end{tabular}

\begin{tabular}{l|l|l|l|l|l|l|l|l|l|l|l|l|l|l|l|l|l|l|l|l|l|l|l|l|l|l|l|l}
\hline & & & & & & & $\mathrm{x}$ & & & & & & & & & & & & & & & & & & & & & \\
\hline & & & & $\mathrm{x}$ & & & & & & & & & & & & $\mathrm{x}$ & & & & & & & & & & & & \\
\hline & & & & & & & & & & & & & & & & & & & & & & & & & & & & \\
\hline & & & & & & & & & & & & & & & & & & & & & & & & & & & & \\
\hline $\mathrm{x}$ & $\mathrm{x}$ & $\mathrm{x}$ & $\mathrm{x}$ & & $\mathrm{x}$ & $\mathrm{x}$ & & $\mathrm{x}$ & $\mathrm{x}$ & & $\mathrm{x}$ & $\mathrm{x}$ & $\mathrm{x}$ & $\mathrm{x}$ & $\mathrm{x}$ & & $\mathrm{x}$ & & $\mathrm{x}$ & & $\mathrm{x}$ & $\mathrm{x}$ & & $\mathrm{x}$ & $\mathrm{x}$ & $\mathrm{x}$ & & $\mathrm{x}$ \\
\hline $\mathrm{x}$ & $\mathrm{x}$ & & & & $\mathrm{x}$ & & & $\mathrm{x}$ & $\mathrm{x}$ & & & $\mathrm{x}$ & $\mathrm{x}$ & $\mathrm{x}$ & $\mathrm{x}$ & $\mathrm{x}$ & $\mathrm{x}$ & $\mathrm{x}$ & $\mathrm{x}$ & & & & & $\mathrm{x}$ & & & $\mathrm{x}$ & $\mathrm{x}$ \\
\hline
\end{tabular}

\begin{tabular}{l|l|l|l|l|l|l|l|l|l|l|l|l|l|l|l|l|l|l|l|l|l|l|l|l|l|l|l|l}
\hline & & & & $\mathrm{x}$ & & & $\mathrm{x}$ & & $\mathrm{x}$ & & & & & & & & & & & & & & & & $\mathrm{x}$ & & $\mathrm{x}$ & \\
\hline & & & & $\mathrm{x}$ & & & $\mathrm{x}$ & & & $\mathrm{x}$ & & & & & & $\mathrm{x}$ & & $\mathrm{x}$ & & $\mathrm{x}$ & & & & & & & $\mathrm{x}$ & \\
\hline & & & & $\mathrm{x}$ & & & & & & & & & & & & & & & & & & & & & & & & \\
\hline $\mathrm{x}$ & & & $\mathrm{x}$ & & & & & $\mathrm{x}$ & & & & & $\mathrm{x}$ & $\mathrm{x}$ & & & & & $\mathrm{x}$ & & & & & & & & & \\
\hline $\mathrm{x}$ & & & $\mathrm{x}$ & $\mathrm{x}$ & & & $\mathrm{x}$ & & & $\mathrm{x}$ & $\mathrm{x}$ & & & & & & & & & & & & & $\mathrm{x}$ & & & & \\
\hline $\mathrm{x}$ & & $\mathrm{x}$ & & & & & & & & & & & $\mathrm{x}$ & $\mathrm{x}$ & & $\mathrm{x}$ & & & $\mathrm{x}$ & & $\mathrm{x}$ & & & & & & \\
\hline
\end{tabular}

\begin{tabular}{l|l|l|l|l|l|l|l|l|l|l|l|l|l|l|l|l|l|l|l|l|l|l|l|l|l|l|l|l}
\hline & & & & & & & & & & & & $\mathrm{x}$ & & $\mathrm{x}$ & & $\mathrm{x}$ & & $\mathrm{x}$ & & $\mathrm{x}$ & $\mathrm{x}$ & & & & & & \\
\hline $\mathrm{x}$ & & & & & & & & & & & & & & & & & & & & & & & & & & $\mathrm{x}$ & & \\
\hline $\mathrm{x}$ & $\mathrm{x}$ & $\mathrm{x}$ & & $\mathrm{x}$ & & & & & & & & & $\mathrm{x}$ & & & & & & & & & & & & $\mathrm{x}$ & &
\end{tabular}




\begin{tabular}{l|c|c|c|c|c|c|c|c|c|c|c|c|c|c|c|c}
\hline & \multicolumn{9}{|c|}{ Mermaid Reef } \\
\hline Rhipiliopsis echinocaulos (Cribb) Farghaly 1986 & 1 & 2 & 3 & 4 & 5 & 6 & 7 & 8 & 9 & 10 & 11 & 12 & 13 & 14 & 15 & 16 \\
\hline Udotea glaucescens J.Agardh 1887 & & & & & & & & & & & & & & & & $\mathrm{X}$ \\
\hline ULVACEAE & $\mathrm{x}$ & & & & & & $\mathrm{X}$ & $\mathrm{x}$ & & & & $\mathrm{x}$ & & $\mathrm{x}$ & & \\
\hline
\end{tabular}

\section{ULVACEAE}

Ulva flexuosa Wulfen 1803

VALONIACEAE

Valonia fastigiata J.Agardh 1887

Valonia ventricosa J.Agardh 1887

Phaeophyceae (Brown Algae)

\section{ECTOCARPACEAE}

Hincksia sp.

\section{DICTYOTACEAE}

Dictyopteris repens (Okamura) Børgesen 1924

Dictyota friabilis Setchell 1926

Dictyota sp.

Lobophora variegata (Lamouroux) Oliviera 1977

Padina boryana Thivy in W.R. Taylor 1966

Stypopodium flabelliforme Weber-van Bosse 1913

SCYTOSIPHONACEAE

Hydroclathrus clathratus (C.Agardh) Howe 1920

Rosenvingea intricata (J.Agardh) Børgesen 1914

\section{SARGASSACEAE}

Turbinaria ornata (Turner) J.Agardh 1848

\section{SPHACELARIACEAE}

Sphacelaria tribuloides Meneghini 1840

Rhodophyceae (Red Algae)

\section{BONNEMAISONIACEAE}

Asparagopsis taxiformis (Delile) Trevisan 1845

\section{CERAMIACEAE}

Aglaothamnion cordatum (Børgesen)

Feldmann-Mazoyer, 1941

Anotrichium tenue (C.Agardh) Nägeli 1862

Antithamnion antillanum Børgesen 1917

Antithamnionella sp.

Centroceras clavulatum (C.Agardh) Montagne 1846

Ceramium codii (Richards) Mazoyer 1938

Ceramiun krameri South \& Skelton 2000

Ceramiun vagans Silva 1987

Corallophila apiculata (Yamada) R.Norris, 1993

Crouania attenuata (C.Agardh) J.Agardh 1842

Gayliella flaccida (Kütz.) Cho et al. 2008

Griffithsia heteromorpha Kützing 1863

Haloplegma duperreyi Montagne 1842

Seirospora orientalis Kraft 1988

Spyridia filamentosa (Wulfen) Harvey 1833

Wrangelia sp.

\begin{tabular}{ll|l|l|l|l|l|l|l|l|l|l|l|l|l|l|l}
\hline & & & & & & & & & & & & & & & \\
\hline & & & & & & & & & & & & & & & $x$ \\
\hline & & & & & & & & & & & & & & & \\
\hline & & $\mathrm{x}$ & $\mathrm{x}$ & & $\mathrm{x}$ & & & $\mathrm{x}$ & & $\mathrm{x}$ & $\mathrm{x}$ & & $\mathrm{x}$ & & $\mathrm{x}$ \\
\hline $\mathrm{x}$ & & & & & & & & & & & & & & & \\
\hline
\end{tabular}

\begin{tabular}{l}
\hline \begin{tabular}{l|l|l|l|l|l|l|l|l|l|l|l|l|l|l|l|l}
20 & & & & & & $\mathrm{X}$ & & & & & & & & & & \\
\hline 14 & & & & & & $\mathrm{x}$ & & & & & & & & & & \\
\hline
\end{tabular} \\
\hline
\end{tabular}




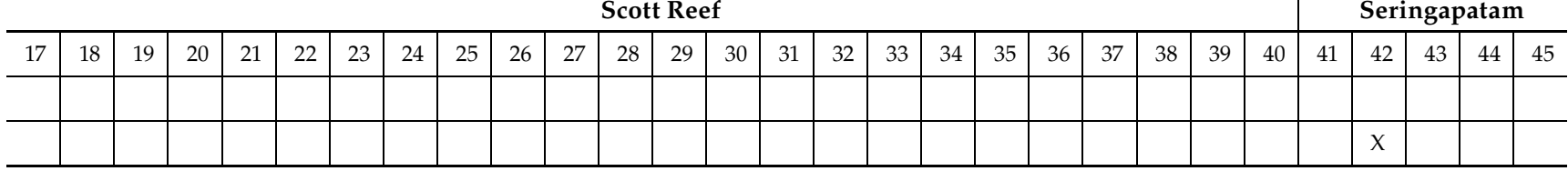

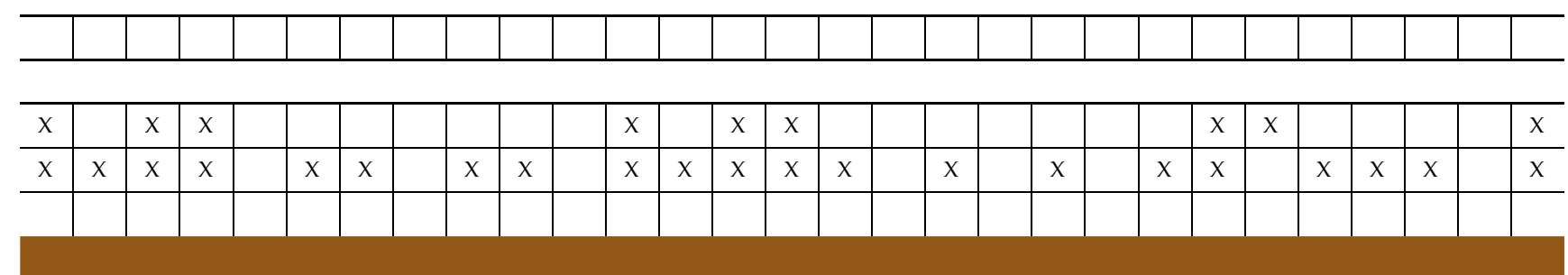

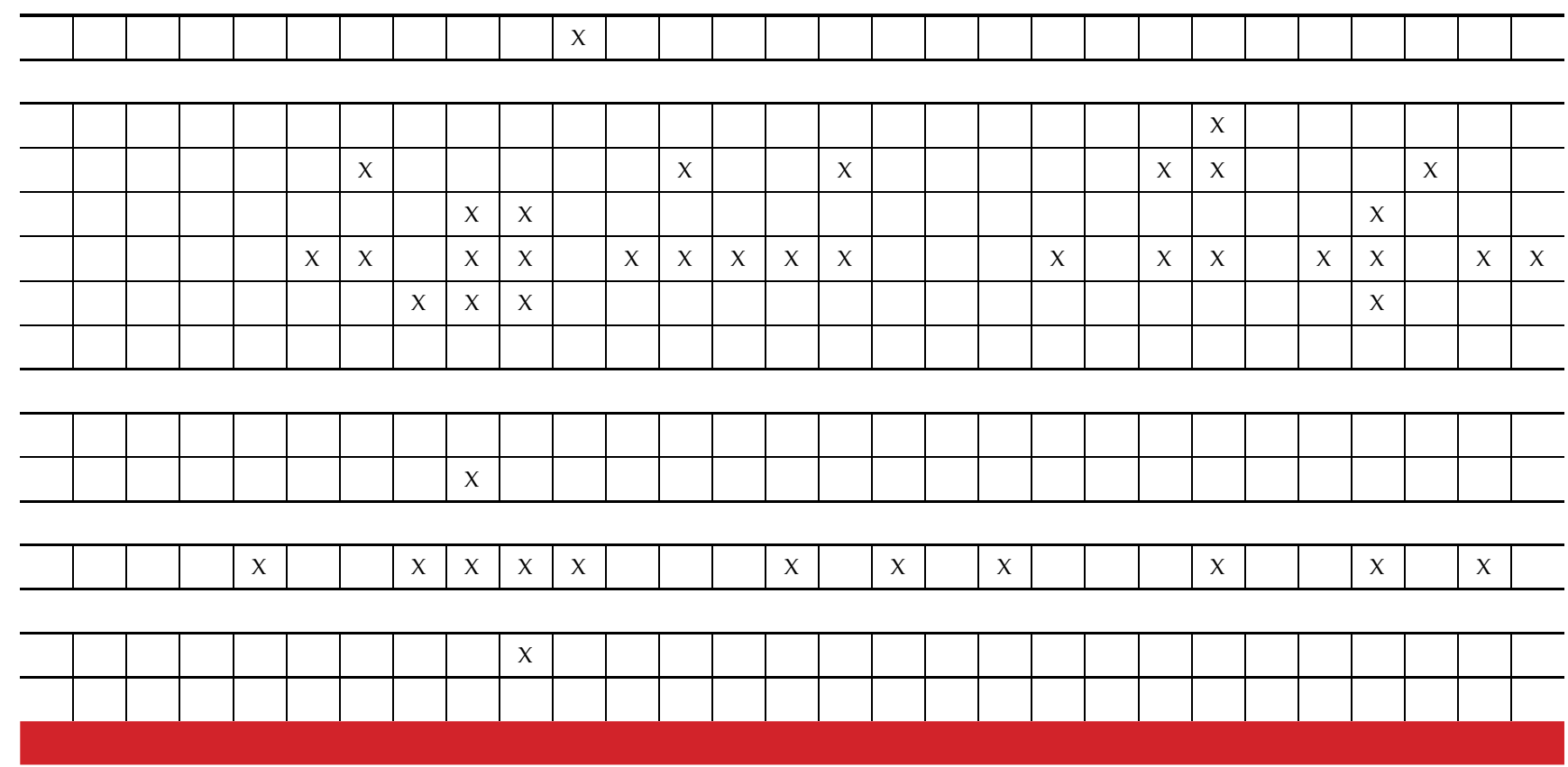

\begin{tabular}{l|l|l|l|l|l|l|l|l|l|l|l|l|l|l|l|l|l|l|l|l|l|l|l|l|l|l|l|l}
\hline \\
\hline
\end{tabular}




\section{CORALLINACEAE}

Amphiroa fragilissima (Linnaeus) Lamouroux 1816

Hydrolithon onkodes (Heydrich)

Penrose \& Woelkerling 1992

Jania adhaerens Lamouroux 1816

Rhizolamellia collum Shevejko 1982

Hydrolithon gardineri (Foslie) Verheij \&

Prud'homme van Reine 1993

Lithophyllum tamiense (Heydrich) Foslie 1900

Lithothamnion proliferum Foslie 1904

\section{CORYNOCYSTACEAE}

Corynocystis prostrata Kraft 1999

\section{DASYACEAE}

Dasya sp.

Heterosiphonia crispella (C.Agardh) Wynne 1985

\section{DELESSERIACEAE}

Zellera tawallina Martens 1868

\section{DUMONTIACEAE}

Gibsmithia hawaiiensis Doty 1963

\section{GALAXAURACEAE}

Actinotrichia fragilis (Forssk.) Børgesen 1932

Dichotomaria marginata (Ellis \& Solander) Lamarck 1816

Galaxaura rugosa (Ellis \& Solander) Lamouroux 1816

Tricleocarpa cylindrica (Ellis \& Solander)

Huisman \& Borowitzka 1990

\section{GELIDIACEAE}

Gelidiella acerosa (Forssk.) Feldmann \& Hamel 1934

Pterocladiella caerulescens (Kützing) Santelices \&

Hommersand 1997

HYPNEACEAE

\begin{tabular}{|c|c|c|c|c|c|c|c|c|c|c|c|}
\hline Hypnea sp. & & & $x$ & & & & & & & & $x$ \\
\hline \multicolumn{12}{|l|}{ KALLYMENIACEAE } \\
\hline \multicolumn{12}{|l|}{ Kallymenia sp. } \\
\hline \multicolumn{12}{|l|}{ LIAGORACEAE } \\
\hline Ganonema pinnatum (Harvey) Huisman 2002 & & & $x$ & & & & & & & & \\
\hline Ganonema farinosum (Lamouroux) Fan \& Wang 1974 & & & & & & & $x$ & & & & \\
\hline \multicolumn{12}{|l|}{ Liagora ceranoides Lamouroux 1816} \\
\hline \multicolumn{12}{|l|}{ Titanophycus validus (Harvey) Huisman et al. 2006} \\
\hline \multicolumn{12}{|l|}{ NEMASTOMATACEAE } \\
\hline Predaea weldii Kraft \& Abbott 1971 & & & & & & & & $x$ & & & \\
\hline Predaea laciniosa Kraft 1984 & & & & & & & & & & & $\mathrm{x}$ \\
\hline \multicolumn{12}{|l|}{ PEYSSONNELIACEAE } \\
\hline Peyssonnelia inamoena Pilger 1911 & $x$ & $\mathrm{x}$ & & $\mathrm{x}$ & $x$ & $x$ & & $\mathrm{x}$ & $x$ & $x$ & $\mathrm{x}$ \\
\hline Peyssonnelia sp. (mottled) & & & & $\mathrm{x}$ & & & & & & & \\
\hline Peyssonnelia sp. (orange) & $\mathrm{x}$ & $\mathrm{x}$ & & & $x$ & & & & $\mathrm{x}$ & $\mathrm{x}$ & \\
\hline \multicolumn{12}{|l|}{ Peyssonnelia sp. (deep red, tightly encrusting) } \\
\hline \multicolumn{12}{|l|}{ PIHIELLACEAE } \\
\hline $\begin{array}{l}\text { Pihiella liagoraciphila Huisman, Sherwood \& Abbott } \\
2003\end{array}$ & & & & & & & & & & & \\
\hline
\end{tabular}




\begin{tabular}{l|l|l|l|l|l|l|l|l|l|l|l|l|l|l|l|l|l|l|l|l|l|l|l|l|l|l|l|l}
\hline 17 & 18 & 19 & 20 & 21 & 22 & 23 & 24 & 25 & 26 & 27 & 28 & 29 & 30 & 31 & 32 & 33 & 34 & 35 & 36 & 37 & 38 & 39 & 40 & 41 & 42 & 43 & 44 & 45 \\
\hline \multicolumn{10}{|c|}{} \\
\hline
\end{tabular}

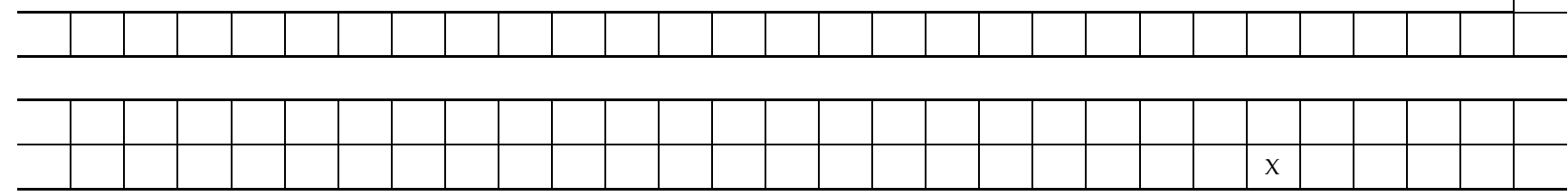

\begin{tabular}{l}
\hline \\
\hline
\end{tabular}

\begin{tabular}{l|l|l|l|l|l|l|l|l|l|l|l|l|l|l|l|l|l|l|l|l|l|l|l|l|l|l|l|l}
\hline & & & $\mathrm{x}$ & & & & & & & & & & & & & & & & & & & & & & & & \\
\hline
\end{tabular}

\begin{tabular}{l}
\begin{tabular}{l|l|l|l|l|l|l|l|l|l|l|l|l|l|l|l|l|l|l|l|l|l|l|l|l|l|l|l|l}
\hline \\
\hline
\end{tabular} \\
\hline
\end{tabular}

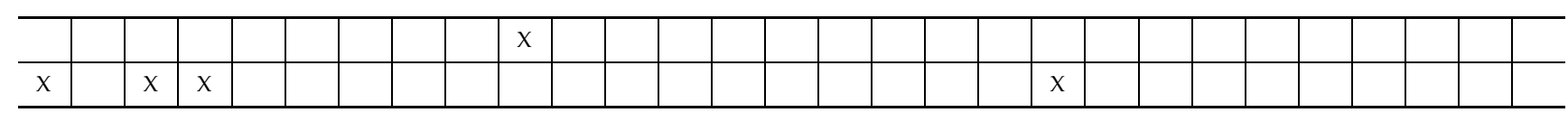

\begin{tabular}{ll|l|l|l|l|l|l|l|l|l|l|l|l|l|l|l|l|l|l|l|l|l|l|l|l|l|l|l|l}
\hline $\mathrm{x}$ & & & & & $\mathrm{x}$ & $\mathrm{x}$ & & & & & $\mathrm{x}$ & $\mathrm{x}$ & $\mathrm{x}$ & $\mathrm{x}$ & $\mathrm{x}$ & & $\mathrm{x}$ & & $\mathrm{x}$ & & $\mathrm{x}$ & $\mathrm{x}$ & & $\mathrm{x}$ & & $\mathrm{x}$ & & $\mathrm{x}$ \\
\hline $\mathrm{x}$ & $\mathrm{x}$ & $\mathrm{x}$ & & & & & & & & & $\mathrm{x}$ & & & & & & & & & & & & & & & & & \\
\hline & & & $\mathrm{x}$ & & $\mathrm{x}$ & & & & & & $\mathrm{x}$ & $\mathrm{x}$ & $\mathrm{x}$ & $\mathrm{x}$ & & & $\mathrm{x}$ & & $\mathrm{x}$ & & $\mathrm{x}$ & & & & & & & $\mathrm{x}$ \\
\hline & & & & & & & & & & & & & & & & & & & & & & & & $\mathrm{x}$ & & & & \\
\hline
\end{tabular}




\begin{tabular}{|c|c|c|c|c|c|c|c|c|c|c|c|c|c|c|c|c|}
\hline \multirow[t]{3}{*}{ TAXA } & \multicolumn{16}{|c|}{ STATIONS } \\
\hline & \multicolumn{16}{|c|}{ Mermaid Reef } \\
\hline & 1 & 2 & 3 & 4 & 5 & 6 & 7 & 8 & 9 & 10 & 11 & 12 & 13 & 14 & 15 & 16 \\
\hline \multicolumn{17}{|l|}{ RHODOMELACEAE } \\
\hline Acanthophora spicifera (Vahl) Børgesen 1910 & $X$ & & & & & $x$ & & & & & & & & & & \\
\hline \multicolumn{17}{|l|}{ Herposiphonia secunda (C.Agardh) Ambronn 1880} \\
\hline \multicolumn{17}{|l|}{$\begin{array}{l}\text { Leveillea jungermannioides (Hering \& G.Martens) } \\
\text { Harvey } 1855\end{array}$} \\
\hline \multicolumn{17}{|l|}{ Neosiphonia poko (Hollenberg) Abbott 2002} \\
\hline \multicolumn{17}{|l|}{ Polysiphonia spp. } \\
\hline \multicolumn{17}{|l|}{ Tolypiocladia glomerulata (C.Agardh) Schmitz 1897} \\
\hline \multicolumn{17}{|l|}{ RHODYMENIACEAE } \\
\hline Asteromenia sp. & & & & & $x$ & & & & & & & & & & & \\
\hline \multicolumn{17}{|l|}{ Ceratodictyon spongiosum Zanardini 1878} \\
\hline Coelothrix irregularis (Harvey) Børgesen 1920 & & & & & & $x$ & & & & & & & & & & \\
\hline \multicolumn{17}{|l|}{ Gelidiopsis intricata (C.Agardh) Vickers 1905} \\
\hline \multicolumn{17}{|l|}{ RHIZOPHYLLIDACEAE } \\
\hline \multicolumn{17}{|l|}{ Portieria hornemannii (Lyngbye) Silva 1987} \\
\hline \multicolumn{17}{|l|}{ SARCOMENIACEAE } \\
\hline \multicolumn{17}{|l|}{$\begin{array}{l}\text { Platysiphonia delicata (Clemente y Rubio) Cremades } \\
1990\end{array}$} \\
\hline \multicolumn{17}{|l|}{ SCHIZYMENIACEAE } \\
\hline \multicolumn{17}{|l|}{ Platoma cyclocolpum (Montagne) Schmitz 1889} \\
\hline \multicolumn{17}{|l|}{ Titanophora pikeana (Dickie) Feldmann 1942} \\
\hline \multicolumn{17}{|l|}{ Cyanobacteria (Blue-green Algae) } \\
\hline \multicolumn{17}{|l|}{ Lyngbya majuscula (Dillwyn) Harvey 1833} \\
\hline \multicolumn{17}{|l|}{ Symploca hydnoides (Harvey) Kützing 1849} \\
\hline \multicolumn{17}{|l|}{$\begin{array}{l}\text { Leptolyngbya crosbyana (Tilden) Anagnostidis } \\
\text { \& Komárek } 1988\end{array}$} \\
\hline \multicolumn{17}{|l|}{ Magnoliophyta (Sea Grasses) } \\
\hline Thalassia hemprichii (Ehrenberg) Aschersson 1871 & & & & & & & & & $\mathrm{X}$ & & $x$ & & & $x$ & & \\
\hline Halophila ovalis (R.Brown) J.D.Hooker 1859 & $X$ & & & & & & $X$ & $x$ & & & $x$ & & & $x$ & & \\
\hline Halophila decipiens Ostenfeld 1902 & & & & & & & & & & & & & & & & \\
\hline
\end{tabular}




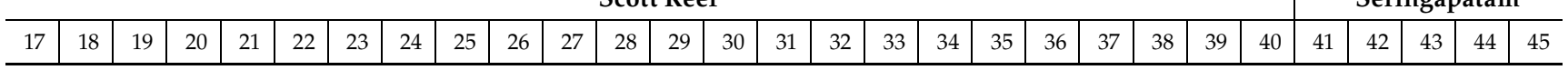

\begin{tabular}{l|l|l|l|l|l|l|l|l|l|l|l|l|l|l|l|l|l|l|l|l|l|l|l|l|l|l|l|l}
\hline & & & & & & & & & & & & & & & & & & & & & & & & & $x$ & & & \\
\hline & & & & & & & & & & & & & & & & $\mathrm{x}$ & & & & & & & $\mathrm{x}$ & & & & & \\
\hline & & & & & & $\mathrm{x}$ & & & & & & & & & & & & & & & & & & & & & \\
\hline
\end{tabular}

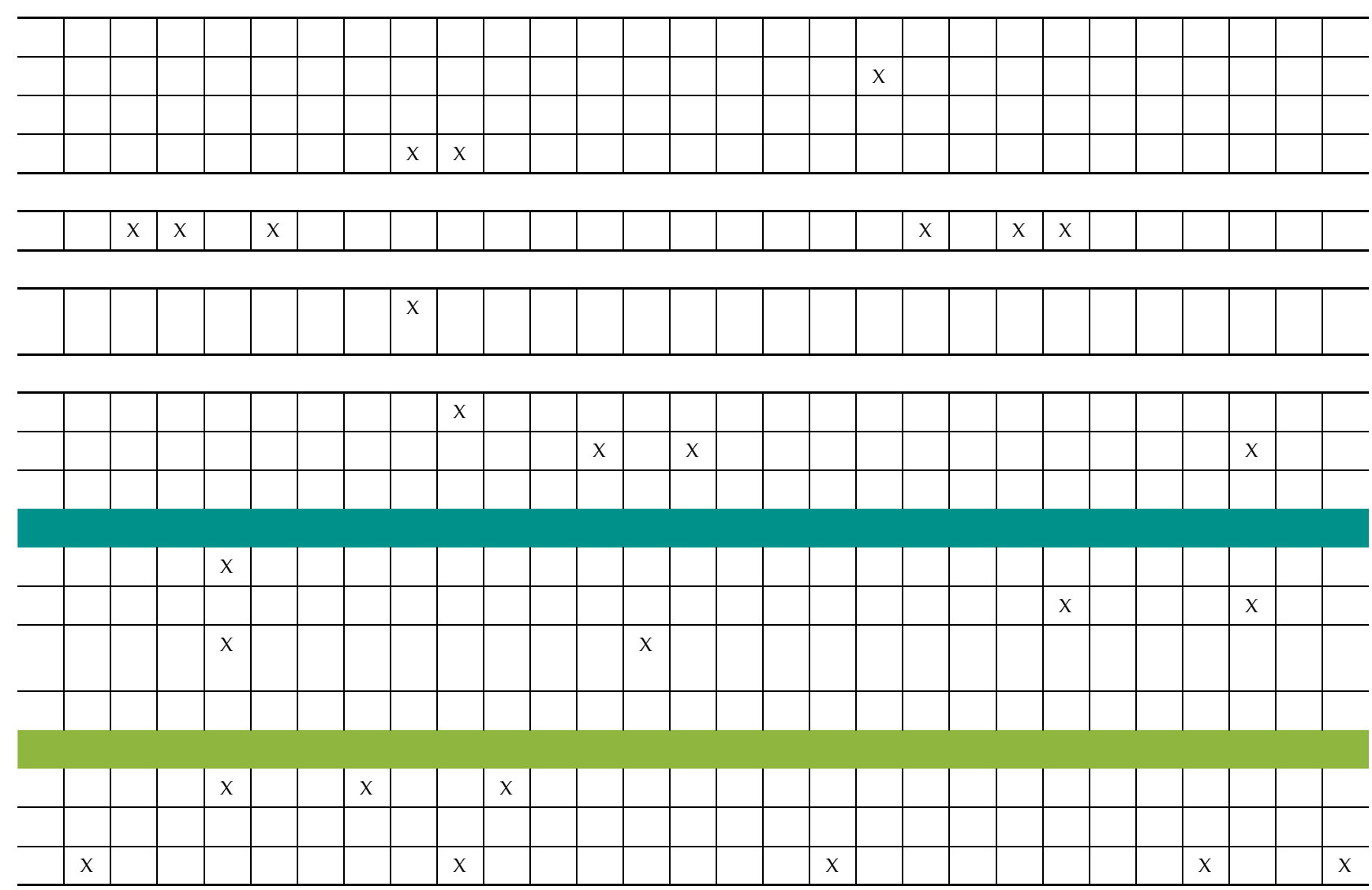


Table 4 New Records for Western Australia ( ${ }^{*}$ new for Australia)

\begin{tabular}{l|l}
\hline Anadyomene wrightii* & Halimeda opuntia \\
Avrainvillea amadelpha & Lithophyllum tamiense \\
Boodlea vanbosseae & Microdictyon okamurae \\
Bryopsis indica & Neomeris bilimbata \\
Ceramium krameri* & Neosiphonia poko \\
Ceramium vagans & Peyssonnelia inamoena \\
Cladophoropsis sundanensis & Phyllodictyon orientale \\
Corynocystis prostrata & Rhipilia crassa \\
Dictyopteris repens & Rhipilia nigrescens* \\
Halimeda distorta & Rhipiliopsis echinocaulos \\
Halimeda macrophysa & Sporolithon ptychoides* \\
Halimeda minima & Zellera tawallina* \\
\hline
\end{tabular}

12), which grew on exposed coral rubble on reef flats. Species of the genus Halimeda were commonly present, as was the green turf Boodlea vanbosseae. Turfs such as Coelothrix irregularis were also common.

Lagoon/bommies - on outcrops the green algae Halimeda opuntia, H. minima and $H$. discoidea generally occurred, the former also typically on the shaded sides and in hollows. Halimeda macrophysa (Figure 11) was occasionally present. The turf green alga Boodlea vanbosseae was almost always present on outcrops, as was the spongy green Boodlea composita. Other turfs included the red algae Polysiphonia spp., Coelothrix irregularis, and Gelidiopsis sp.

Sandy pools - Halimeda cylindracea was common in shallow sandy habitats, where its large bulbous holdfasts gave it some purchase. Also in these situations were Halimeda macroloba (Figure 10) and Udotea glaucescens (Figure 14). In some sandy habitats Caulerpa cupressoides and Caulerpa serrulata were also common. All of these species are adapted

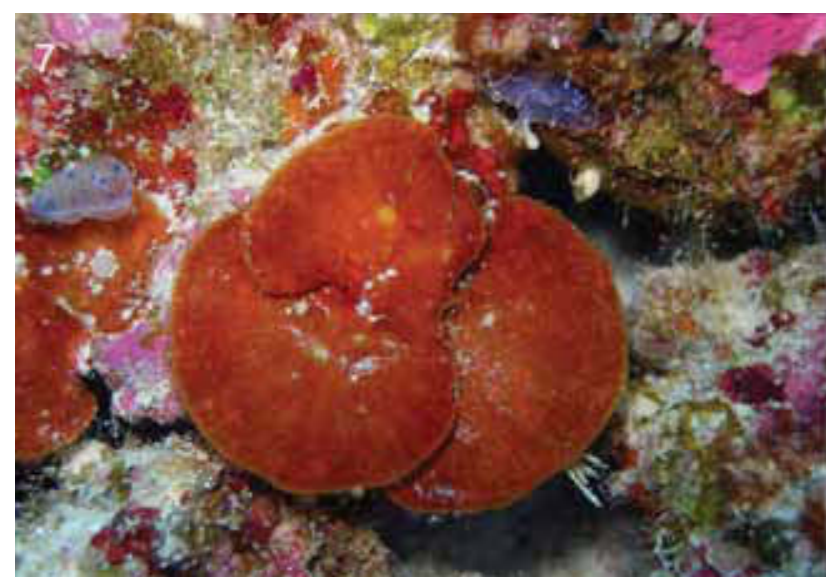

Figure 7 Peyssonnelia inamoena, on vertical walls in many habitats to growth in unconsolidated substrata, either by producing sand-binding bulbous holdfasts or by having prostrate stolons that attach at numerous points. In turn, the Halimeda and Caulerpa provide habitats for numerous epiphytic species, such as Padina sp., Herposiphonia secunda, Anotrichium tenue, Gayliella flaccida and Centroceras clavulatum. The seagrasses Thalassia hemprichii (Figure 13) and Halophila ovalis were occasionally common in shallow sandy areas, the former sometimes forming small but dense beds. The occurrence of Halophila decipiens in deeper water, as suggested by video evidence in the URS report, is confirmed for Scott and Seringapatam Reefs.

\section{DISCUSSION}

Over 120 species of macroalgae and seagrasses are reported for the Rowley Shoals, Scott Reef and Seringapatam Reef. This represents a significant contribution towards documenting the marine flora of these reefs. Once the smaller, cryptic epiphytic algae are fully assessed, the species

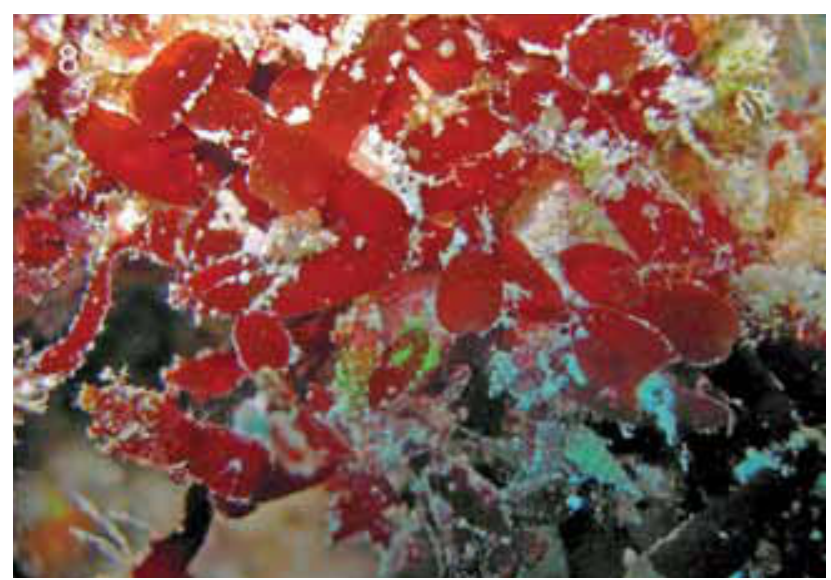

Figure 8 Corynocystis prostrata, newly recorded for Western Australia 
number will probably approach 140 . Several of the specimens collected represent new records for Australia or Western Australia, including the red alga Corynocystis prostrata Kraft and the green alga Rhipiliopsis echinocaulos (Cribb) Farghaly (see Table 4). As these reefs have not been intensively sampled previously, the majority of the species represent new records.

From an algal perspective there were very few differences in the floras of the Rowley Shoals, Scott and Seringapatam Reefs, and most of those noted were probably site specific or habitat related rather than between reef differences. The higher energy reef fronts typically supported the encrusting coralline Hydrolithon onkodes near the crest. This species is characteristic of this zone in most IndoPacific reefs. The mat-forming green alga Cladophora herpestica was common on vertical walls in shallow, relatively exposed locations at the Rowley Shoals, whereas it was seemingly absent from Scott and Seringapatam Reefs. This species furnishes perhaps the only clear floristic difference between the two reef systems. Other species from reef front habitats were often associated with dark recesses within the vertical walls. These include species such as Peyssonnelia inamoena and the recently described Corynocystis prostrata, both new records for Western Australia.

At Seringapatam there were more dense stands of the brown alga Turbinaria ornata, a species

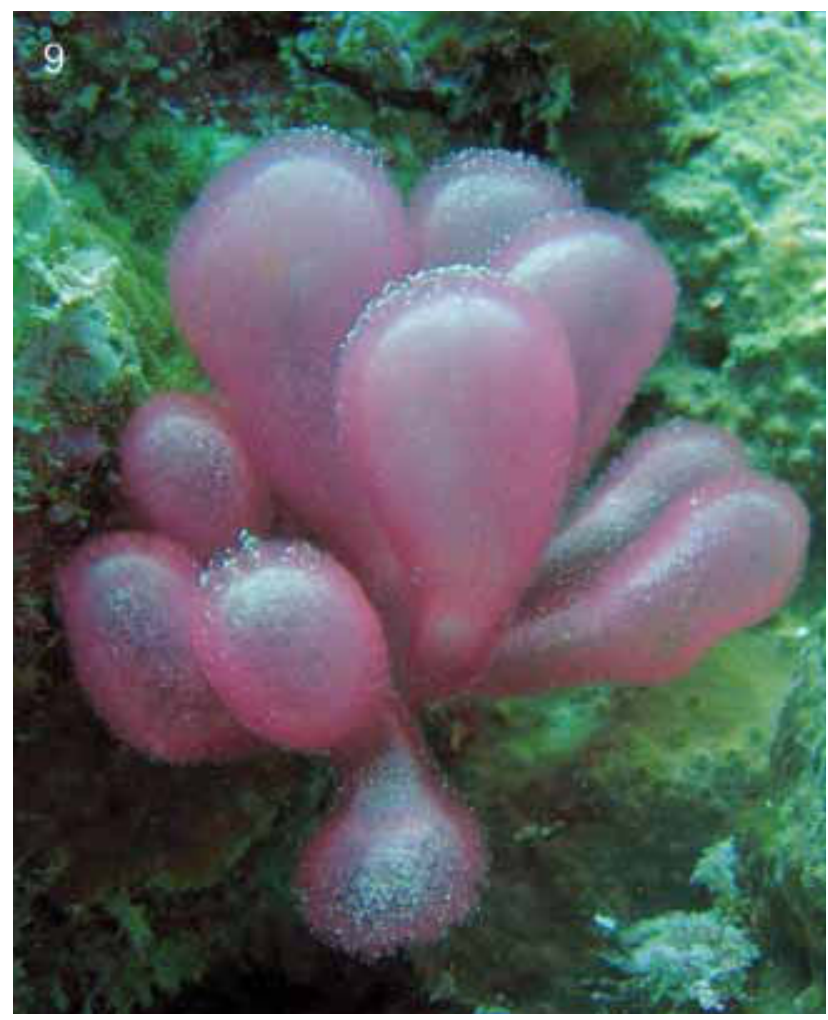

Figure 9 Gibsmithia hawaiiensis, an unusual gelatinous red alga. that was observed less frequently at the Rowley Shoals and Scott Reef. In places at Seringapatam it covered the reef entirely, but this was very patchy. This contrasts to the observation of Skewes et al., (1999), who recorded a greater cover of Turbinaria at Scott Reef compared to Seringapatam. These differences are probably not significant and reflect within-reef or seasonal variation. The green turf Boodlea vanbosseae also formed dense but patchy stands on reef flats. This species was recorded less frequently at the Rowley Shoals but reflects the fact that suitable habitats were not visited. Most other recorded species occurred at all three reefs and in similar densities. There were several species recorded from single specimens (e.g. Platoma cyclocolpum at Stn 26). Most of the commonly observed species occurred at the three reefs.

\section{Mermaid/Scott/Seringapatam Reefs compared to the Indo-Pacific Biogeographic Region}

The Indo-Pacific algal flora is very diverse and covers a large area. Some subsets of the region are regarded as biodiversity hotspots, for example the Philippines with some 900 species recorded (Silva et al., 1987), but this high diversity often also reflects collection effort. Macroalgal studies in some regions have been ongoing for over a century (e.g. Indonesia, beginning with Weber-van Bosse \& Foslie 1904) and these regions continue to be studied by primarily European botanists (e.g

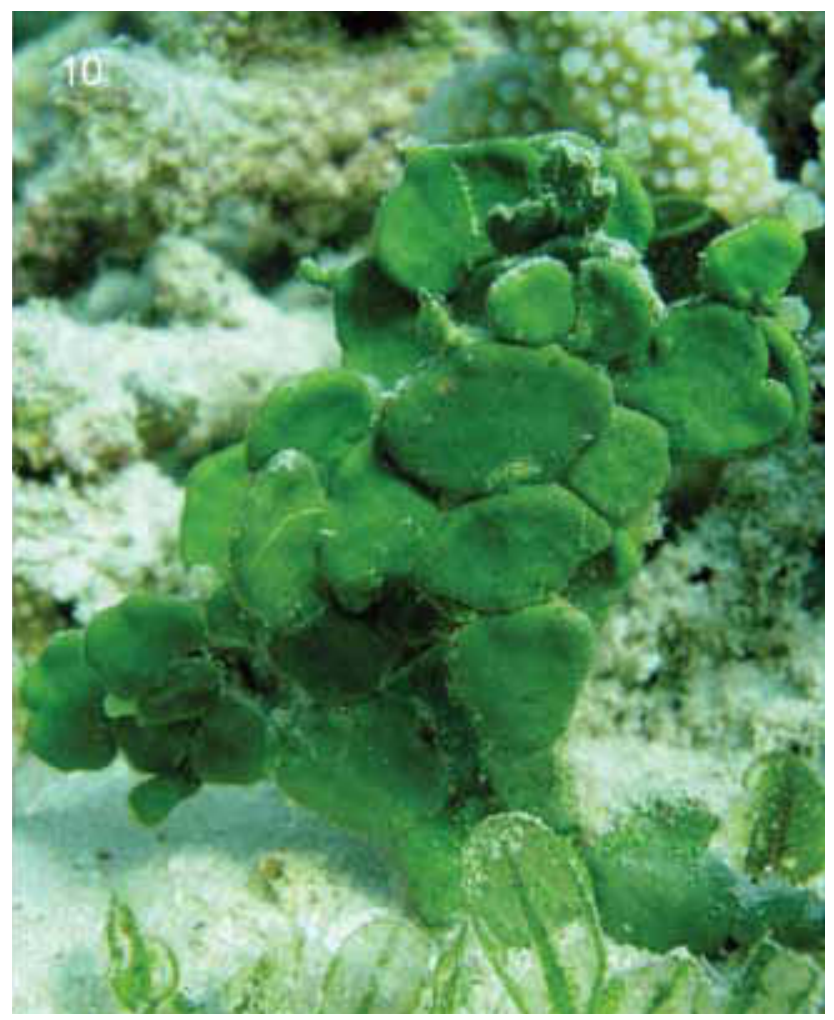

Figure 10 Halimeda macroloba, a species restricted to sandy habitats 


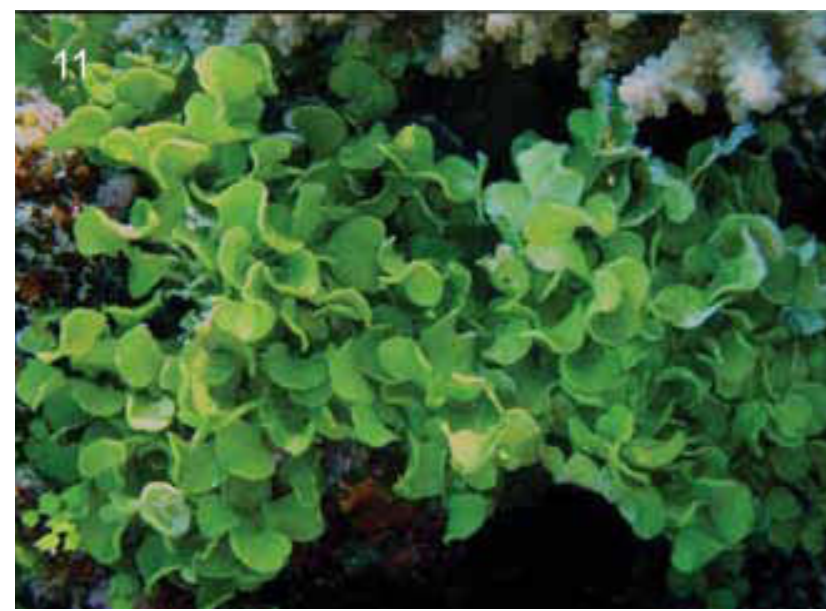

Figure 11 Halimeda macrophysa, with ruffled segments

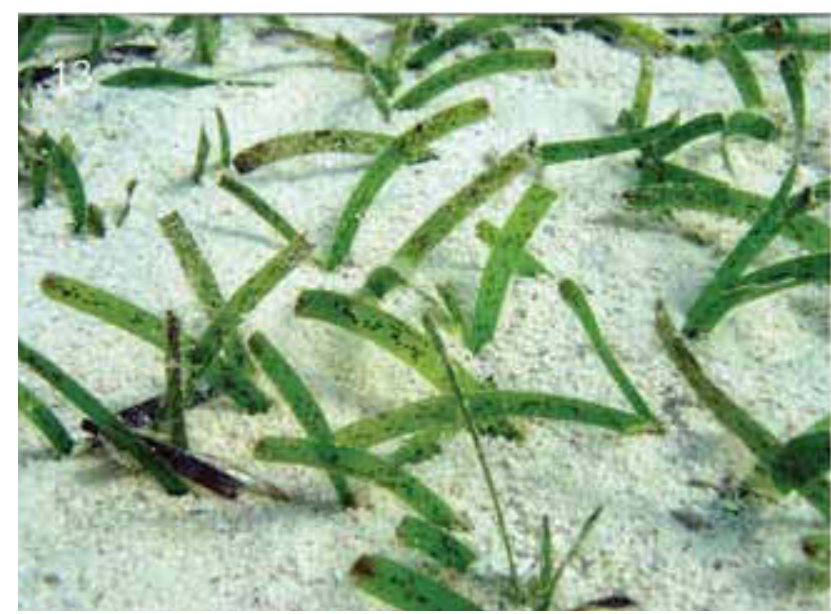

Figure 13 Thalassia hemprichii, occasionally in dense stands in sandy habitats

Verheij \& Prud'homme van Reine 1993). However, much of the Indo-Pacific region is also currently poorly known, particularly so tropical northwestern Australia where, up until some 8 years ago, less than 30 algal species were recorded (Huisman et al., 1998). Ongoing studies are rapidly changing this situation and presently the known (but mostly unpublished) northwestern Australian flora totals over 350 species. Specimens of possibly another 100 species have been collected, but these are as yet unidentified (unpublished obs.). Thus any assessment of the Rowleys/Scott/Seringapatam algal floras must be viewed against this backdrop, acknowledging that there is much that is still unknown.

The algal flora of the Rowley Shoals, Scott and Seringapatam Reefs forms a small subset of the Indo-Pacific algal flora, with virtually all of the species identified thus far having been previously collected from north-western Australia or from localities further north. Several of the collected species represent new records for Western Australia, but these are likely to be revealed as much more widespread once more extensive

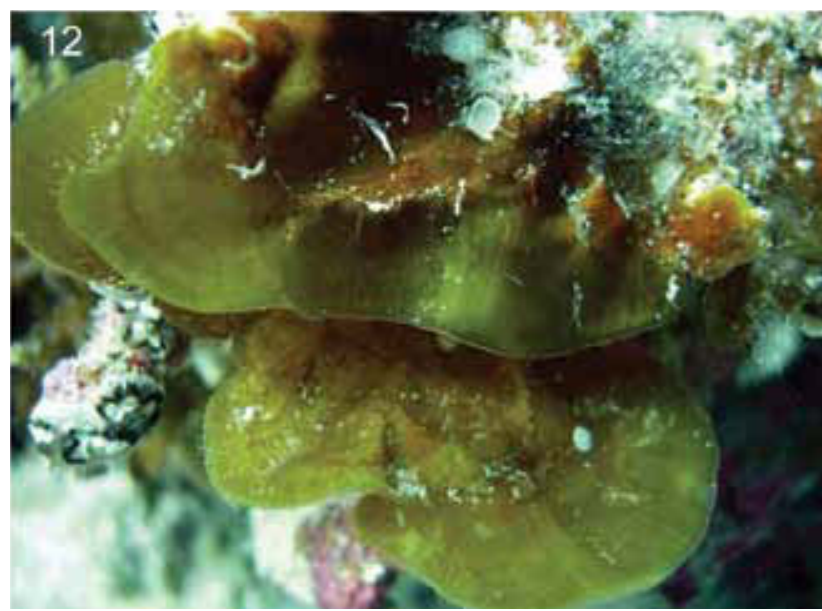

Figure 12 Lobophora varegiata, common in lagoonal habitats.

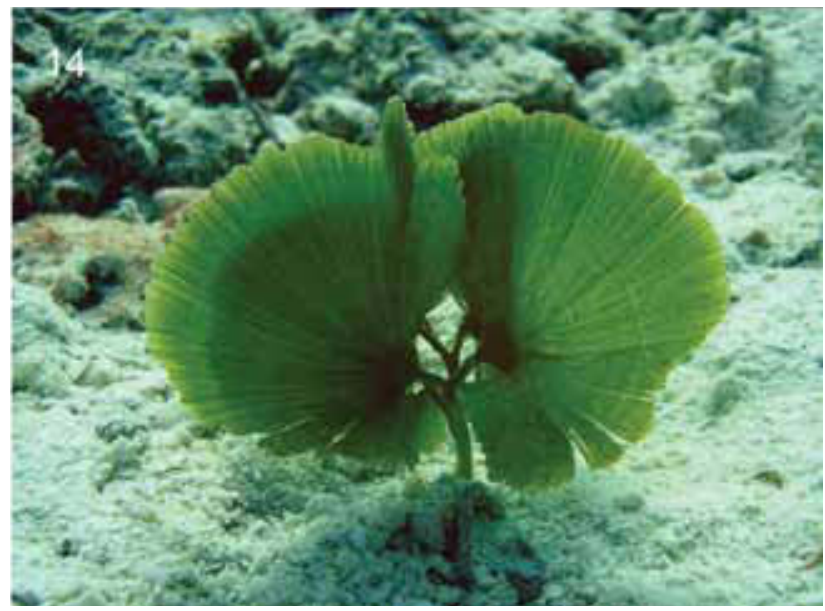

Figure 14 Udotea glaucescens, a fan shaped green alga.

collections are made from the region. From an algal perspective, there is nothing to suggest that the Rowley Shoals, Scott and Seringapatam Reefs are unique within the Indo-Pacific. A comparison of the total number of species recorded from various regions and localities is given in Table 3 . This is obviously a superficial comparison, as neither collecting effort, area, nor habitat diversity is taken into account. Nevertheless, it does serve to illustrate that the reefs support only a small number of macroalgal species.

\section{Mermaid/Scott/Seringapatam reefs compared to the mainland}

Compared with the northwest coast of the mainland, the diversity of Scott Mermaid/Scott/ Seringapatam Reefs is markedly lower. Over 350 species are recorded from the mainland (Huisman, unpublished observations), whereas only approximately 120 species were found at the reefs. This disparity is obviously biased by the larger area and more diverse habitats of the mainland, plus a greater sampling effort. Nevertheless, even comparably smaller subsets of the mainland (e.g. 
Barrow Island with 170 spp.; Huisman, unpublished obs.) show a greater diversity than that found at the offshore atolls. Moreover, several taxa common in the Indo-Pacific and often typical of tropical regions were not found. The most conspicuous in their absence were the brown algal genera Sargassum and Cystoseira. Other usually species-rich genera were only represented by a small number of species. For example, 16 species and varieties of the green alga Caulerpa have been recorded from the northwestern Australian mainland, but only five species were found at the offshore atolls. The reasons for this low diversity are uncertain, as suitable microhabitats for many of these taxa appear to be present at the reefs.

\section{FURTHER OUTCOMES}

Specimens of the rare Rhizolamellia collum Shevejko 1982 (previously known only from the type collection from Scott Reef) were collected and will form the basis of a separate taxonomic and DNA sequence study to assess the affinities of this enigmatic genus. Other studies generated wholly or in part by these collections, or to which specimens have been contributed, include a reassessment of Boodlea vanbosseae (Leliaert et al., 2007), an assessment of Phyllodictyon orientale (Leliaert et al., 2008), an analysis of the affinities of Australian Acanthophora spicifera (McDonald \& Sherwood, in prep.) and the description of a new species of Asteromenia (Huisman \& Saunders, in prep.). Moreover, all of the species recorded will be included in the 'Marine Benthic Flora of Northwestern Australia' (Huisman, in prep.) and all of the in situ specimen photographs (of which only a selection are included here) will be made available on the Department of Environment and Conservation's 'FloraBase' website.

\section{CONCLUSIONS}

The algal flora of the Rowley Shoals, Scott and Seringapatam reefs represents a small subsection of the highly diverse Indo-Pacific flora, with the majority of species recorded during the present survey having been previously recorded from mainland northwestern Australia or from Indonesia. Some 100 species of macroalgae and seagrasses are reported for the reefs (a doubling of the previously known flora), but once cryptic and turf species are fully examined this number is likely to increase further to $\pm 140 \mathrm{spp}$. Several species represent new records for Australia (Zellera tawallina) or Western Australia (Corynocystis prostrata, Rhipiliopsis echinocaulos, Halimeda macrophysa).

The algal floras of the three reef systems were essentially similar. Differences between stations were observed, but these were primarily habitat based (i.e. reef front versus reef flat versus lagoon). Several species were characteristic of each of these habitats at the three reefs.

\section{TAXONOMIC ACCOUNT}

Taxa are arranged into Divisions (Chlorophyta = green algae, Heterokontophyta: Phaeophyceae $=$ brown algae, Rhodophyta = red algae, Cyanophyta = cyanobacteria $=$ blue-green algae, Magnoliophyta = seagrasses. Divisions are subdivided into Orders, Families, Genera and Species, generally arranged according to Silva et al., (1996). Species are arranged alphabetically and each entry includes nomenclatural information, an 'Illustrations' section for previously published photographs or drawings, distribution information, and a list of selected specimens. Habitat notes pertain to local collections. In specimen citations, 'URS' refers to the February 2006 URS survey, and 'NWA' refers the to September 2006 WA Museum survey. Where no PERTH accession numbers are given, the specimens are yet to be curated and databased. Further information can be obtained from the first author. The format of this compendium essentially follows that of earlier catalogues of marine plants for Western Australia (Huisman, 1997; Huisman \& Borowitzka, 2003; Goldberg \& Kendrick, 2005).

\section{Division Chlorophyta (Green Algae) Order CHAETOPHORALES Family CHAETOPHORACEAE URONEMA Lagerheim, 1887: 518.}

Uronema marinum Womersley, 1984: 131.

Type Locality: Coffin Bay, South Australia, epiphytic on Chaetomorpha linum. Illustrations: Kraft, 2007: Figure 6. Distribution: Tropical and temperate regions of the Indo-west Pacific; epiphytic. Specimens: Mermaid Reef, Rowley Shoals, lagoon bommie near south tip of reef (NWA Stn 14), epiphytic on Dictyota sp., 16 Sept. 2006, J.M. Huisman (PERTH). Scott Reef (NWA Site 31), 23 Sept. 2006, epiphytic on Microdictyon okamurae Setch. in crevices in shallows, J.M. Huisman (on PERTH 07720343). Remarks: This is a small filamentous epiphyte that is probably widespread in Australian seas.

\author{
Order ULVALES \\ Family ULVACEAE \\ ULVA Linnaeus, 1753: 1163. \\ Type Locality: Duino, near Trieste, Italy.
}

Ulva flexuosa Wulfen, 1803: 1. Illustrations: Kraft, 2007: 39-41, figure 15. 
Distribution: Probably cosmopolitan; on sand, rock or epiphytic. Specimens: Seringapatam Reef, south east reef flat, (URS Tr. 35), 22 Feb. 2006, J.M. Huisman (PERTH 07788932). Remarks: This species formed a dense bloom on a sand flat (see Figure 1). Distal branches of the specimens are extremely elongate, unbranched and remain a uniform width throughout their length, remarkably similar to Ulva ralfsii (Harvey) Le Jolis. However, that species forms free-floating or entangled masses (Womersley, 1984: 152, as Enteromorpha ralfsii; Kraft 2007: 35), unlike the present specimens. Basal branching occurs in the Seringapatam Reef specimens and also the occasional uniseriate filament, features that suggest Ulva flexuosa subsp. paradoxa (C. Agardh) Kraft (2007). Further studies (including DNA sequence analyses) are desirable, however, to confirm this identification.

\section{Order CLADOPHORALES Family CLADOPHORACEAE CLADOPHORA Kützing, 1843: 262.}

\section{Cladophora coelothrix Kützing, 1843: 272.}

Type Locality: Golfo di Genova, Italy. Illustrations: Van den Hoek, 1963: 40-43, plate 5, figures 55-67, plate 6, figures $68-71$, plate 7 , figures $72-77$, plate 8, figure 78; Leliaert \& Coppejans, 2003, figure 2. Distribution: tropical to warm-temperate seas; intertidal to subtidal. Specimens: Seringapatam Reef, (URS Tr. 22, Tr. 32), 22 Feb. 2006, J.M. Huisman (GENT). Remarks: Molecular data revealed that $C$. coelothrix is placed in the Siphonocladales clade, along with a number of other Cladophora species, including C. socialis, C. prolifera, C. liebetruthii, C. catenata and C. sibogae (Leliaert et al., 2007). Cladophora coelothrix is comprised of multiple cryptic species with tropical representatives forming a clade that is unrelated to the European representatives.

\section{Cladophora socialis Kützing, 1849: 416.}

Type locality: Tahiti. Illustrations: Van den Hoek, 1963: $43,46-47$, plate 8 , figures $79-85$, plate 9, figures 86-91; 1982: 52-57, figures 30-40); Leliaert \& Coppejans, 2003, figure 3. Distribution: tropical to warm-temperate regions of the Atlantic and Indo-Pacific Oceans; intertidal. Specimen: Scott Reef, (URS Tr. 28), mixed with Cladophoropsis sundanensis, 21 Feb. 2006, J.M.Huisman (GENT). Remarks: Cladophora socialis closely resembles $C$. coelothrix from which it mainly differs by its smaller cell diameter. Molecular data showed that $C$. socialis is nested within the tropical C. coelothrix clade (Leliaert et al., 2007).
Cladophora herpestica (Montagne) Kützing 1849: 415.

Conferva herpestica Montagne, 1842: 15. Type Locality: Bay of Islands, New Zealand. Illustrations: Huisman, 2000: 239 (as Cladophoropsis herpestica). Kraft 2007: Figure 36. Distribution: Houtman Abrolhos, Western Australia, to Queensland; IndoPacific; Japan; New Zealand. Specimens: Imperieuse Reef, Rowley Shoals, outer east side, 4 Dec. 2007, J.M. Huisman (PERTH 07729340). Meramid Reef, Rowley Shoals, outer slope east side, (NWA Stn 5), 13 Sept. 2006, J.M. Huisman (PERTH 07626584). Remarks: Most records of this species are as Cladophoropsis herpestica (Montagne) Howe (e.g. Womersley, 1984; Huisman, 2000), but Leliaert \& Coppejans (2006) showed that the taxon aligned more closely with Cladophora (see also Kraft, 2007).

\section{Order SIPHONOCLADALES}

Family ANADYOMENACEAE

ANADYOMENE Lamouroux, 1812: 187.

Anadyomene plicata C. Agardh, 1823: 400-401.

Type Locality: 'Ravak' [Rauki], Waigeo Island, Moluccas, Indonesia. Illustrations: Huisman, 2000: 232 (as A. brownii). Distribution: Known from northern Australia south to the Houtman Abrolhos on the west coast. Indonesia. Solomon Islands. Philippines; epilithic in the intertidal and shallow subtidal. Specimens: Mermaid Reef, Rowley Shoals, outside slope middle east side, 13 Sept. 2006, J.M. Huisman (PERTH 07626576). Scott Reef, channel (NWA Stn 40) 25 Sept. 2006, J.M. Huisman (PERTH 07719183). Remarks: This species has previously been reported from north-western Australia as $A$. brownii, but there seems little to distinguish that species from the earlier-named A. plicata.

Anadyomene wrightii Harvey ex J.E.Gray, 1866: 48-49, plate 44: Figure 5.

Type Locality: Ryukyuretto, Japan [Loochoo Islands]. Illustrations: Abbott et al., 2002. Distribution: Widespread in tropical waters of the Indian and Pacific Oceans. Specimens: Mermaid Reef, Rowley Shoals (NWA Stn 14) 16 Sept. 2006, J.M. Huisman (PERTH 078165510). Remarks: This species is similar in appearance to $A$. plicata, but differs in the axial cells becoming subdivided and remaining uncorticated. This is a new record for Western Australia and Australia.

\section{MICRODICTYON Decaisne, 1841: 115}

Microdictyon okamurae Setchell, 1925: 107.

Type Locality: Ryukyu Island, Japan. Illustrations: Setchell, 1929: Figures 76-84. Distribution: Warmer waters of the Indo-Pacific. Specimens: Scott Reef 
(NWA Site 31), 23 Sept. 2006, in crevices in shallows, J.M. Huisman (PERTH 07720343). Remarks: This represents a new record for Western Australia.

\section{PHYLLODICTYON J.E.Gray, 1866: 69}

Phyllodictyon orientale (A.Gepp \& E.Gepp) Kraft \& Wynne, 1996: 139-140.

Struvea orientalis A.Gepp \& E.Gepp, 1908: 167-168, plate 22: Figures 6-9; 1909: 377-378, plate 47: Figures 6-9. Type Locality: SW of Poivre Atoll, Amirante Isles, Seychelles. Illustrations: Kraft \& Wynne, 1996: Figures 22-45. Leliaert \& Coppejans, 2007: Figures 22-45. Distribution: P. orientale is only known from some scattered localities in the Indo-Pacific, generally growing in deep subtidal biotopes (Leliaert \& Coppejans, 2007). Specimens: Mermaid Reef, Rowley Shoals, in channel at $21 \mathrm{~m}$ depth (NWA Stn 13), 16 Sept. 2006, J.M. Huisman (PERTH 07788894). Scott Reef, (NWA Stn 38), 25 Sept. 2006, J.M. Huisman (GENT 17 / F624). Remarks: Specimens from the Rowley Shoals and Scott Reef collected during the present surveys were included in molecular analyses by Leliaert et al., (2008) and were identical to specimens from near the Seychelles type locality. This represents a new record for Western Australia.

\section{Family SIPHONOCLADACEAE}

\section{BOODLEA G.Murray \& De Toni, 1889: 245.}

Boodlea composita (Harvey) Brand, 1904: 187.

Conferva composita Harvey, 1834: 157. Type Locality: Cap Malheureux, N-coast of Mauritius. Illustrations: Oliveira et al., 2005: 199. Huisman, 2000: 238. Kraft, 2000: Figure 24A-C. Huisman et al., 2007: 172. Distribution: Widespread in tropical and warmer seas. Specimens: Clerke Reef, Rowley Shoals, lagoon, 11 Dec. 2007, J.M. Huisman (PERTH 07729235).

\section{Boodlea vanbosseae Reinbold, 1905: 148.}

Type Locality: Lucipara Island, Indonesia. Illustrations: Leliaert et al., 2007: Figures 1-23 (Figure 14 is from Scott Reef). Distribution: Known from several locations in the tropical waters of the Indian and West Pacific Oceans (see Leliaert et al., 2007); in Australia from northern WA and south-eastern Queensland (Cribb, 1960). Specimens: Mermaid Reef, Rowley Shoals, NE corner of reef, 13 Sept. 2006, J.M. Huisman (PERTH 07626525). Remarks: B. vanbosseae is common at Scott Reef and Seringapatam Reef, where it forms low, dense mats on hard substrata. The analyses of Leliaert et al., (2007, including NW Australian material) clearly indicate that the species is not a member of Boodlea, and instead aligned closely with Cladophora catenata in the Anadyomene clade. Leliaert et al., (2007) did not make any taxonomic changes pending further revision.
BOERGESENIA Feldmann, 1938: 1504.

Boergesenia forbesii (Harvey) Feldmann, 1938: 1503.

Valonia forbesii Harvey, 1860: 333. Type Locality: Ryukyu-retto, Japan; Sri Lanka. Illustrations: Huisman, 2000: 237; Oliveira et al., 2005: 198. Distribution: Widespread in the tropical Indo-West Pacific; in Australia recorded from the central and northern Great Barrier Reef and tropical Western Australia from Ningaloo Reef northward; epilithic in the intertidal/shallow subtidal, often in clusters at the edges of shallow pools. Specimens: Scott Reef (URS Tr. 2), intertidal, 16 Feb. 06, J.M. Huisman (PERTH 07816383). Remarks: This species occupies a very restricted habitat, occurring only in the intertidal on the edges of rock pools or at the rock/ sand interface.

\section{DICTYOSPHAERIA Decaisne ex Endlicher, 1843: 18.}

Dictyosphaeria cavernosa (Forssk.) Børgesen, 1932: 2.

Ulva cavernosa Forssk., 1775: 187. Type Locality: "Gomfodae" (Al-Qunfidha), Saudi Arabia; Mokha, Yemen. Illustrations: Huisman, 2000: 240. Huisman et al., 2007: 173. Distribution: Widely distributed in tropical and subtropical seas. Epilithic in the intertidal and shallow subtidal, often in small clusters. Specimens: Scott Reef (South), east side (URS Tr. 17), 19 Feb. 2006, J.M. Huisman (PERTH 07788924). Seringapatam Reef, intertidal, eastern side south of channel (URS Tr. 32), 22 Feb. 2006, J.M. Huisman (PERTH).

Dictyosphaeria versluysii Weber-van Bosse, 1905: 144.

Type Locality: Indonesia. Illustrations: Huisman et al., 2007: 173. Distribution: Widely distributed in tropical and subtropical seas. Specimens: Imperieuse Reef, Rowley Shoals, east side, in shallows, 5 Dec. 2007, J.M. Huisman (PERTH). Remarks: Differs from D. cavernosa in its solid rather than hollow habit. Plants also tend to be a gray-green colour, whereas D. cavernosa is typically dark green.

\section{CLADOPHOROPSIS Børgesen, 1905: 288.}

Cladophoropsis sundanensis Reinbold, 1905: 147.

Lectotype locality: Kangean, Indonesia. Illustrations: Leliaert \& Coppejans, 2006: Figures 40-46. Distribution: Indo-Pacific and Mediterranean Sea (also been reported from the Atlantic Ocean); high intertidal to shallow subtidal. Specimen: Scott Reef, 21 Feb. 2006 (URS Tr. 28) (mixed with Cladophora socialis), J.M. Huisman (GENT). Remarks: Cladophoropsis sundanensis can be distinguished from C. membranacea by its narrower filaments. 


\section{Family VALONIACEAE}

VALONIA C. Agardh, 1823: 428.

Valonia fastigiata Harvey ex J. Agardh, 1887: 101.

Type Localities: Sri Lanka; Tonga. Illustrations: Littler \& Littler, 2003: 206-207.

Specimens: Scott Reef (South), north east outer slope (NWA Stn 30), 22 Sept. 2007, J.M. Huisman (PERTH 07720246). Scott Reef, channel (NWA Stn 40), 25 Sept. 2006, J.M. Huisman (PERTH 07719191).

Remarks: This species forms hummocks of tightly packed, vesiculate branches.

Valonia ventricosa J.Agardh, 1887: 96.

Type Locality: Guadeloupe, West Indies. Illustrations: Huisman, 2000: 243 (as Ventricaria ventricosa). Distribution: Widely distributed in tropical and subtropical seas. Epilithic in the shallow subtidal. Specimens: Imperieuse Reef, Rowley Shoals, 2 Dec. 2007, J.M. Huisman (PERTH 07789327). Remarks: Previously reported as Ventricaria ventricosa (J.Agardh) Olsen \& J.West, but this species, originally segregated from Valonia, has been returned to that genus based on the molecular analyses of Leliaert et al., (2003) (a move first made by Kraft, 2007). Valonia ventricosa is known by the common name 'sailor's eyeballs' and can be very common and conspicuous on reef substrata, particularly in higher energy zones.

\section{Order BRYOPSIDALES}

\section{Family CHAETOSIPHONACEAE \\ BLASTOPHYSA Reinke, 1889: 87.}

\section{Blastophysa rhizopus Reinke, 1889: 87.}

Type Locality: Kieler Förde, Germany (Baltic Sea). Illustrations: Kraft, 2000: 587, figure 30A-D. Huisman et al., 2007: 184. Distribution: Widespread in temperate and tropical seas; endophytic in various soft-bodied algae. Specimens: Scott Reef (South), entrance to false lagoon (NWA Stn 25), endophytic in Ganonema farinosum, 21 Sept. 2006, J.M. Huisman (PERTH 07816650).

\section{Family BRYOPSIDACEAE}

BRYOPSIS Lamouroux, 1809: 333.

Bryopsis indica A.Gepp \& E.Gepp, 1908: 169-170, plate 22, figures 10, 11.

Type Locality: Chagos Archipelago, Seychelles, Mauritius, Sri Lanka. Illustrations: Kraft, 2007: Figure 102. Distribution: Known from various locations in the tropical Indo-Pacific. Specimens: Clerke Reef, Rowley Shoals, from $5 \mathrm{~m}$ depth, $9 \mathrm{Dec}$. 2007, J.M. Huisman (PERTH). Remarks: The local specimens are identical to those described by Kraft
(2007) from eastern Australia. This represents a new record for Western Australia.

\section{Family CAULERPACEAE}

CAULERPA Lamouroux, 1809: 332

Caulerpa cupressoides (Vahl) C.Agardh, 1817: XXIII.

Fucus cupressoides Vahl, 1802: 38. Type Locality: St. Croix, Virgin Is. Illustrations: Huisman, 2000: 250. Distribution: Widely distributed in tropical seas. Occurs in the shallow subtidal, associated with sandy/silty substrata.

Specimens: Scott Reef (South), near Guano wreck, intertidal, 16 Feb. 2006, J.M. Huisman (PERTH 07720297). Scott Reef (South), southeast side (URS Tr. 12), 18 Feb. 2006, J.M. Huisman (PERTH 07788940).

\section{Caulerpa lentillifera J. Agardh, 1837: 2.}

Type Locality: Ethiopia. Illustrations: Huisman, 2000: 253. Kraft, 2007: plate 6C, figures 68A-C. Distribution: Widespread in the tropical IndoPacific. Occurs in the shallow subtidal, associated with sandy substrata. Specimens: Mermaid Reef, Rowley Shoals, lagoon, 4 Dec. 2007, J.M. Huisman (PERTH 07729278).

Caulerpa serrulata (Forsskål) J. Agardh, 1837: 174.

Fucus serrulatus Forsskål, 1775: 189. Type Locality: Mokha, Yemen. Illustrations: Huisman, 2000: 257; Huisman et al., 2007: 182. Distribution: Widely distributed in tropical seas. Epilithic in the intertidal and subtidal. Specimens: Imperieuse Reef, Rowley Shoals, 2 Dec. 2007, J.M. Huisman (PERTH 07729316). Mermaid Reef, Rowley Shoals, lagoon near channel, 14 Dec. 2007, J.M. Huisman (PERTH 07789394). Scott Reef (South), near Guano wreck, intertidal, 16 Feb. 2006, J.M. Huisman (PERTH 07720505). Seringapatam Reef, Sth side outer slope at $20 \mathrm{~m}$ depth, (NWA Stn 41) 26 Sept. 2006, J.M. Huisman (PERTH 07720351).

Caulerpa taxifolia (Vahl) C.Agardh, 1817: XXII.

Fucus taxifolius Vahl, 1802: 36. Type Locality: St. Croix, Virgin Is. Illustrations: Huisman, 2000: 258259. Huisman et al., 2007: 183. Distribution: Widely distributed in tropical seas. Epilithic on rock or sand. Specimens: Mermaid Reef, Rowley Shoals (NWA Stn 6), 14 Sept. 2006, J.M. Huisman (PERTH 07788835). Seringapatam Reef, at lagoon edge/ platform interface at $10 \mathrm{~m}$ depth (NWA Stn 42), 26 Sept. 2006, J.M. Huisman (PERTH 07725256)

Caulerpa verticillata J. Agardh, 1847: 6.

Type Locality: Not specified. Illustrations: Taylor, 1960: 138-139, plate 10, figures 1, 2. Distribution: 
Widely distributed in warmer waters of the Indian and Pacific Oceans and Caribbean; epilithic on sand-covered rock in the shallow subtidal. Specimens: Seringapatam Reef, at lagoon edge/ platform interface at $10 \mathrm{~m}$ depth (NWA Stn 42), 26 Sept. 2006, J.M. Huisman (PERTH 07725205).

\section{Caulerpa webbiana Montagne, 1837: 354.}

Type Locality: Arrecife, Isla Lanzarote, Islas Canarias [Canary Is.]. Illustrations: Huisman, 2000: 259. Huisman et al., 2007: 183. Distribution: Widespread in tropical and warmer seas; grows on rock or sand. Specimens: Mermaid Reef, Rowley Shoals, in shallows on inner side of western reef (NWA Stn 6), 14 Sept. 2006, J.M. Huisman (PERTH 07788827).

\section{Family CODIACEAE}

CODIUM Stackhouse, 1797: Xvi, xxiv.

Codium arabicum Kützing, 1856: 35, plate 100, figure 2 .

Type Locality: Tor, Sinai Peninsula, Gulf of Suez. Illustrations: Jones \& Kraft, 1984: 255-258, figures 1-2. Van den Heede \& Coppejans, 1996: 391-392, figures 1, 5, 7. Distribution: Indo-Pacific Tropics. Specimens: Mermaid Reef, Rowley Shoals, lagoon bommie on west side at $10 \mathrm{~m}$ depth (NWA Stn 7), 14 Sept. 2006, J.M. Huisman (PERTH 07718772).

Codium dwarkense Børgesen, 1947: 6-8, figures 3-5.

Type Locality: Dwarka and Port Okha, Gujarat, India. Illustrations: Van den Heede \& Coppejans, 1996: 397-398, figures 4, 6, 14. Distribution: Known from India, east Africa, and northwestern Australia; epilithic in the intertidal. Specimens: Mermaid Reef, Rowley Shoals, lagoon bommie on west side at 10 m depth (NWA Stn 8), 14 Sept. 2006, J.M. Huisman (PERTH).

\section{Family HALIMEDACEAE}

HALIMEDA Lamouroux, 1812: 186.

\section{Halimeda cylindracea Decaisne, 1842: 103.}

Type Locality: Nosy-Bé, Madagascar. Illustrations: Huisman, 2000: 264. Hillis-Colinvaux, 1980: Figures $4,5,104$. Distribution: Warmer waters of the IndoPacific; typically grows in unconsolidated substrata. Specimens: Scott Reef (North) (URS Tr. 23), 20 Feb 2006, J.M. Huisman (PERTH).

Halimeda distorta (Yamada) Hillis-Colinvaux, 1968: 33.

Halimeda incrassata f. distorta Yamada, 1941: 119, figure 14. Type Locality: Atoll of Ant, Ponape, East Caroline Islands, Micronesia. Illustrations: Yamada,
1944: 28, plate 4. Hillis-Colinvaux, 1980: Figure 34. Specimens: South Scott Reef, on wellhead in deep lagoon, 19 June 2007, B.Wilson \& URS (PERTH 07816715). Remarks: Video footage indicates that Halimeda distorta can occur in dense beds at Scott Reef. Similarly dense Halimeda banks were reported for the Big Bank Shoals in the Timor Sea (Smith et al., http://www.aims.gov.au/pages/reflib/bigbank/ pages/bb-08.html). While the species was not identified, the images suggest it is likely to be $H$. distorta. Coverages of up to $35 \%$ were reported and the Halimeda was regarded as one of the dominant carbonate structures.

Halimeda macroloba Decaisne, 1841: 118. (Figure 10)

Type Locality: Red Sea. Illustrations: HillisColinvaux, 1980: Figure 28. Distribution: Common in the Indian and west Pacific Oceans, generally growing in unconsolidated substrata. Specimens: Mermaid Reef, Rowley Shoals, Sth end lagoon, 14 Sept. 2006, J.M. Huisman (PERTH 07643934). Scott Reef, on sandy lagoon floor at $2 \mathrm{~m}$ depth, J.M.Huisman (PERTH). Remarks: This species is distinctive amongst the sand-inhabiting Halimeda in producing flat segments.

Halimeda macrophysa Askenasy, 1888: 14, plate 4, figures 1-4. (Figure 11)

Type Locality: Matuku, Fiji Islands. Illustrations: Hillis-Colinvaux, 1980: 134, figures 40; Kraft, 2007: Plate 8C; figures 74F-K. Distribution: Widespread in the Indo-West Pacific; in Western Australia known only from the Rowley Shoals. Specimens: Mermaid Reef, Rowley Shoals, lagoon east side at $10.5 \mathrm{~m}$ depth (NWA Stn 1), 12 Sept. 2006, J.M.Huisman (PERTH 07719051). Mermaid Reef, lagoon, 14 Dec. 2007, J.M. Huisman (PERTH 07729251). Remarks: This distinctive species was found only on a couple of occasions, forming loose clusters attached to reef outcrops in lagoonal sites.

Halimeda minima (W.R.Taylor) Colinvaux, 1968: 32. (Figure 4)

Halimeda opuntia f. minima Taylor, 1950: 82-83, 206. Type Locality: Bikini Lagoon, Bikini Atoll, Marshall Islands. Distribution: Widespread in the Indo-West Pacific. Specimens: Mermaid Reef, Rowley Shoals, west side at $8 \mathrm{~m}$ depth, 13 Dec. 2007, J.M. Huisman (PERTH). Remarks: This species is variable in gross morphology, with some specimens having reniform segments and others distinctly trilobed. They are united by their internal structure and dimensions of the peripheral utricles in surface view (10-25 $\mu \mathrm{m}$ diameter).

Halimeda opuntia (Linnaeus) Lamouroux, 1816: 308.

Corallina opuntia L., 1758: 805. Type Locality: 
Jamaica. Illustrations: L.Hillis-Colinvaux, 1980: 41, figure 19. Distribution: Common in the tropics worldwide; forms imbricating patches between coral. Local specimens were often collected from shallow reef flats. Specimens: Mermaid Reef, Rowley Shoals, lagoon east side at $10.5 \mathrm{~m}$ depth (NWA Stn 1), 12 Sept. 2006, J.M.Huisman (PERTH 07719094). Scott Reef (South), intertidal, near Guano wreck, 16 Feb. 2006, J.M. Huisman (PERTH 07720491).

\section{Family UDOTEACEAE}

\section{AVRAINVILLEA Decaisne, 1842: 108.}

Avrainvillea amadelpha (Montagne) A.Gepp \& E.Gepp, 1908: 178.

Udotea amadelpha Montagne, 1857: 136. Type Locality: Galega I., Indian Ocean. Illustrations: Olsen-Stojkovich, 1985: 37, figure 19. Distribution: Widespread in the tropical waters of the IndoPacific. Specimens: Scott Reef, (NWA Stn 34), 24 Sept. 2006, J.M.Huisman (PERTH 07789211). Remarks: This species in regarded as an introduced pest in the Hawaiian Islands (Huisman et al., 2007).

\section{RHIPIDOSIPHON Montagne, 1842: 14.}

Rhipidosiphon javensis Montagne, 1842: 14.

Type Locality: Leiden Island [Nyamuk-besar], near Jakarta, Java, Indonesia. Illustrations: Huisman et al., 2007: 191. Distribution: Tropical waters of the eastern Indian Ocean and western and central Pacific. Specimens: Seringapatam Reef, at lagoon edge/ platform interface at $10 \mathrm{~m}$ depth (NWA Stn 42), 26 Sept. 2006, J.M.Huisman (PERTH 07725078).

\section{RHIPILIA Kützing, 1858: 12}

\section{Rhipilia crassa Millar \& Kraft, 2001: 32.}

Type Locality: Heron Is., Capricorn Group, southern Great Barrier Reef, Qld. Illustrations: Millar \& Kraft, 2001: Figures 37-40, 53-58. Distribution: Known from the southern Great Barrier Reef, the Philippines, and Scott Reef. Specimens: Scott Reef (South), south side outer edge (NWA Stn 17), 18 Sept. 2006, J.M. Huisman (PERTH). Seringapatam Reef, inner lagoon reef (NWA Stn 43), 26 Sept. 2006, J.M. Huisman (PERTH 07816502). Remarks: R. crassa is closely related to $R$. nigrescens, which is also recorded from Scott Reef in similar habitats. This might suggest that the two entities are conspecific. Siphons of R. crassa, however, are much larger than those found in $R$. nigrescens. Moreover, specimens of both species were included in DNA phylogenetic analyses, the results of which clearly indicated that two taxa are present (Verbruggen, pers. comm. 2007).

Rhipilia nigrescens Coppejans \& Prud'homme van Reine, 1990: 261. (Figure 3)

Type Locality: Tukang Besi Is., W coast of Binongko, Indonesia. Illustrations: Coppejans \& Prud'homme van Reine, 1989: 128, plate 5. Distribution: Indonesia; Papua New Guinea; Scott Reef. Specimens: Scott Reef (South), south side outer edge (NWA Stn 17), 18 Sept. 2006, J.M. Huisman (PERTH). Remarks: Both this species and Rhipilia crassa represent new records for Western Australia, the former also a new record for Australia.

\section{RHIPILIOPSIS A.Gepp \& E.Gepp, 1911: 45.}

Rhipiliopsis echinocaulos (Cribb) Farghaly, in Kraft, 1986: 54.

Geppella echinocaulos Cribb, 1960: 6. Type Locality: Caloundra, near Brisbane, Queensland, Australia. Illustrations: Kraft, 1986: Figures 12-16. Kraft, 2007: Plate 10C, figure 87. Distribution: Known from tropical Australia and southern Japan, possibly also China; epilithic in the subtidal. Specimens: Scott Reef (NWA Stn 25), 21 Sept. 2006, J.M. Huisman (PERTH 07816464). Remarks: Rhipiliopsis echinocaulos is known from only a single collection of several plants, but it is probably widespread in the region. Plants grow to only a few millimetres in height and are easily missed in the field.

\section{UDOTEA Lamouroux, 1812: 186.}

Udotea glaucescens Harvey ex J.Agardh, 1887: 70. (Figure 14)

Type Locality: Tonga, on shaded rocks in lagoon. Illustrations: Gepp \& Gepp, 1911: figures 3, 5, 7, 8, 43. Coppejans \& Prud'homme van Reine, 1989: plate 10, figures 1, 2. Distribution: Tropical Indo-Pacific; generally in sand. Specimens: Imperieuse Reef, Rowley Shoals, 2 Dec. 2007, J.M. Huisman (PERTH 07789335). Clerke Reef, Rowley Shoals, lagoon, 11 Dec. 2007, J.M. Huisman (PERTH 07729219). Mermaid Reef, Rowley Shoals, south end of inner lagoon at $11.9 \mathrm{~m}$ depth (NWA Stn 14), 16 Sept. 2006, J.M. Huisman (PERTH 07725094). Remarks: Udotea glaucescens is generally easily recognized due to its blades being borne in clusters and with filaments visible from the surface. The individual filaments often disassociate and result in the thallus having a frayed appearance. Living specimens are a green colour, but when dried they become grey-green, as suggested by the specific epithet.

\section{Order DASYCLADALES}

NEOMERIS Lamouroux, 1816: 241.

Neomeris bilimbata Koster, 1937: 221, plate 15, figures $1,4,5$.

Type Locality: Itu Aba Island, Tizard Bank, South China Sea. Illustrations: Kraft 2007: Figure 108. 
McCarthy \& Orchard, 2007: Plate 36. Distribution: Recorded from numerous locations in the tropical Indo-Pacific. In Australia from Lord Howe Island (Kraft, 2007). Epilithic. Specimens: Scott Reef, intertidal (URS Tr. 2), 16 Feb. 2006, J.M. Huisman (PERTH). Clerke Reef, Rowley Shoals, from 5 m depth, 9 Dec. 2007, J.M. Huisman (PERTH 07789351). Remarks: These specimens are identical to those described by Kraft (2007) from Lord Howe Island, including producing distinctively stalked gametophores and deltoid secondary laterals. This represents a new record for Western Australia.

\section{Heterokontophyta: Phaeophyceae (Brown Algae) \\ Order DICTYOTALES}

\section{Family DICTYOTACEAE}

\section{DICTYOPTERIS Lamouroux, 1809: 332.}

Dictyopteris repens (Okamura) Børgesen, 1924: 265, figure 13.

Haliseris repens Okamura, 1916: 8. Type Locality: Truk Islands, Caroline Islands. Illustrations: Allender \& Kraft, 1983: Figures 19A, B. Phillips, 2000: Figures 10g-h. Distribution: Widespread in tropical and subtropical seas. Specimens: Clerke Reef, west side. 8 Dec. 2007, J.M. Huisman (PERTH 07789424). NWA Stn 5, J.M. Huisman (PERTH). Scott Reef, lagoon bommie (NWA Stn 39), 25 Sept. 2006, J.M. Huisman (PERTH). Remarks: D. repens is closely related to $D$. delicatula, differing in the absence of a thickened marginal rib. This represents a new record for Western Australia.

\section{DICTYOTA Lamouroux, 1809a: 38.}

Dictyota friabilis Setchell, 1926: 12: 91-92, plate 13, figures 4-7; plate 20, figure 1.

Type Locality: Tafaa Point, Tahiti. Illustrations: De Clerck, 2003: pls 22, 23. Distribution: Warmer waters of the Indo-Pacific; forms mats on hard substrate of the outer reef slope. Specimens: Clerke Reef, Rowley Shoals, lagoon, 7 Dec. 2007, J.M. Huisman (PERTH 07729111). Scott Reef (South), entrance to false lagoon (NWA Stn 25), 21 Sept. 2006, J.M. Huisman (PERTH 07725507).

\section{LOBOPHORA J. Agardh, 1894: 21}

Lobophora variegata (Lamouroux) Womersley ex Oliviera, 1977: 217. (Figure 12)

Dictyota variegata Lamouroux, 1809a: 40. Type Locality: Antilles. Illustrations: Huisman, 2000: 193. Distribution: Known from tropical to warm temperate coasts in most seas. Generally epilithic in the subtidal. Specimens: Imperieuse Reef, Rowley Shoals, lagoon, 4 Dec. 2007, J.M. Huisman (PERTH
07789270). Mermaid Reef, Rowley Shoals, inner lagoon, east side at $10.5 \mathrm{~m}$ depth (NWA Stn 1), 12 Sept. 2006, J.M. Huisman (PERTH 07719086). Remarks: Lobophora variegata is extremely common at the atolls, often forming dense imbricating mats on Acropora in lagoon habitats. On reef flats the crustose form of this species occurs.

\section{PADINA Adanson, 1763: 13, 586.} 2.

Padina boryana Thivy in Taylor, 1966: 355, figure

Type locality: 'Friendly Islands' = Tonga, Polynesia. Illustrations: Allender \& Kraft, 1983: Figures 5D, E. Distribution: Widespread in the Indo-Pacific and eastern Atlantic. Epilithic or epiphytic. Specimens: Mermaid Reef, Rowley Shoals, inner side of western reef (NWA Stn 6), 14 Sept. 2006, J.M. Huisman (PERTH). Scott Reef (South), Intertidal. Reef flat near Guano wreck (URS Tr. 2), 16 Feb. 2006, J.M. Huisman (PERTH 07720262). Scott Reef (North), lagoon, 23 Sept. 2006, J.M. Huisman (PERTH 07720041)

\section{STYPOPODIUM Kützing, 1843: 341}

Stypopodium flabelliforme Weber-van Bosse, 1913: 176.

Type Locality: Rotti Island, Indonesia, and Pearl Bank, Tawitawi Province, Sulu Archipelago. Illustrations: Huisman, 2000: 198. Huisman et al., 2006: 29. Distribution: Widespread in the warmer waters of the Indo-Pacific. In Australia from Busselton, W.A., around northern Australia to Lord Howe Island and Jervis Bay, N.S.W.; epilithic in the subtidal. Specimens: Clerke Reef, Rowley Shoals, lagoon, 7 Dec. 2007, J.M. Huisman (PERTH 07729138). Mermaid Reef, Rowley Shoals, inner lagoon east side at $10.5 \mathrm{~m}$ depth (NWA Stn 1), 12 Sept. 2006, J.M. Huisman (PERTH 07719043). Imperieuse Reef, Rowley Shoals, 6 Dec. 2007, J.M.Huisman (PERTH 07729359).

\section{Order SPHACELARIALES \\ Family SPHACELARIACEAE \\ SPHACELARIA Lyngbye, 1819: 103.}

Sphacelaria tribuloides Meneghini, 1840: 2.

Type Locality: Gulf of Spezia, northern Italy. Distribution: Widespread in tropical and temperate seas. Illustrations: Womersley 1987: 160, figures 45G, 52A-C. Specimens: Scott Reef (South), reef flat (URS Tr. 12), 18 Feb. 2006, J.M. Huisman (PERTH 07724632).

\section{Order SCYTOSIPHONALES}

Family SCYTOSIPHONACEAE 


\section{HYDROCLATHRUS Bory, 1825: 419}

Hydroclathrus clathratus (C. Agardh) Howe, 1920: 590

Encoelium clathratum C. Agardh, 1822: 412. Type Locality: Uncertain. Illustrations: Womersley, 1987: 300, figures 109A, 110A, B. Huisman, 2000: 204. Distribution: Widely distributed in tropical to warm temperate seas. Specimens: Mermaid Reef, Rowley Shoals, inner side of western reef in shallows (NWA Stn 6), 14 Sept. 2006, J.M. Huisman (PERTH).

\section{ROSENVINGEA Børgesen, 1914: 22 (178)}

Rosenvingea intricata (J. Agardh) Børgesen, 1914: 26.

Asperococcus intricatus J. Agardh, 1847: 7. Type Locality: Veracruz, Mexico. Illustrations: Oliveira et al., 2005: 173. Distribution: Widespread in warmer seas. Specimens: Mermaid Reef, Rowley Shoals, inner side of western reef in shallows (NWA Stn 6), 14 Sept. 2006, J.M. Huisman (PERTH 07788843).

\section{Order FUCALES}

\section{Family SARGASSACEAE}

TURBINARIA Lamouroux, 1825: 71.

Turbinaria ornata (Turner) J.Agardh, 1848: 266. (Figure 1)

Fucus turbinatus L. var. ornata Turner, 18071808: 50-53, plate 24: Figures c, d. Type Locality: Not known. Illustrations: Huisman, 2000: 226. Distribution: Widespread in tropical seas. In Western Australia, from the tropics south to Coral Bay; generally on reef flats. Specimens: Mermaid reef, Rowley Shoals, intertidal on north-east corner, 13 Sept. 2006, J.M Huisman (PERTH 07626312). Scott Reef (South) east side (URS Tr. 17), 19 Feb. 2006, J.M. Huisman (PERTH 07788916).

\section{Rhodophyceae (Red Algae) Order NEMALIALES}

Family GALAXAURACEAE

\section{ACTINOTRICHIA Decaisne, 1842: 118.}

Actinotrichia fragilis (Forsskål) Børgesen, 1932: 6 , plate 1 , figure 4

Fucus fragilis Forsskål, 1775: 190. Type Locality: Mokha, Yemen. Illustrations: Huisman, 2000: 37. Huisman, 2006: Figures 3A, 4A, plate 4. Distribution: Widespread in tropical seas; epilithic. Specimens: Clerke Reef, Rowley Shoals, lagoon near channel, 10 Dec. 2007, J.M. Huisman (PERTH 07789386). Mermaid Reef, Rowley Shoals, lagoon entrance channel (NWA Stn 13), 16 Sept. 2006, J.M. Huisman (PERTH 07718764). Seringapatam Reef, inner lagoon reef (NWA Stn 43), 26 Sept. 2006, J.M. Huisman
(PERTH 07720335).

\section{DICHOTOMARIA Lamarck, 1816: 143.}

Dichotomaria marginata (Ellis \& Solander) Lamarck, 1816: 146. (Figure 5)

Corallina marginata Ellis \& Solander, 1786: 115, plate 22, figure 6. Type Locality: Bahama Islands, West Indies. Illustrations: (as Galaxaura marginata) Huisman \& Borowitzka, 1990: 157-161, figures 14-27. Huisman, 2000: 38. Distribution: Widely distributed in warmer seas. Epilithic in the subtidal. Specimens: Mermaid Reef, Rowley Shoals, Sth end of inner lagoon at $11.9 \mathrm{~m}$ depth, 16 Sept. 2006, J.M. Huisman (PERTH 07725124). Remarks: More widely known as Galaxaura marginata (Ellis \& Solander) Lamouroux, this species was recently restored to a resurrected Dichotomaria Lamarck by Huisman et al., (2004) following DNA sequence analyses.

\section{GALAXAURA Lamouroux, 1812: 185.}

Galaxaura rugosa (Ellis \& Solander) Lamouroux, 1816: 236.

Corallina rugosa Ellis \& Solander, 1786: 115, plate 22, figure 3. Type Locality: Jamaica. Illustrations: Huisman \& Borowitzka, 1990: 153-157, figures 1-13. Huisman, 2000: 39. Distribution: Widely distributed in warmer seas. Epilithic in the subtidal and lower intertidal. Specimens: Scott Reef (South), on reef flat (URS Tr. 12), 18 Feb. 2006, J.M. Huisman (PERTH 07788800). Scott Reef (North), intertidal (NWA Stn 33), 23 Sept. 2006, J.M. Huisman (PERTH 07720033). Remarks: In addition to typical G. rugosa, specimens referable to Galaxaura filamentosa were collected from some high energy sites. Australian records of the latter were regarded as representing $G$. rugosa by Huisman \& Borowitzka (1990) and the Rowley Shoals specimens will be subjected to DNA sequence analyses to confirm this opinion.

\section{TRICLEOCARPA Huisman \& Borowitzka,, 1990:} 164.

Tricleocarpa cylindrica (Ellis \& Solander) Huisman \& Borowitzka, 1990: 164.

Corallina cylindrica Ellis \& Solander, 1786: 114, plate 22, figure 4. Type Locality: West Indies. Illustrations: Huisman \& Borowitzka, 1990: Figures 40-45, 50-52. Huisman, 2000: 41. Distribution: Widespread in tropical seas. Specimens: Scott Reef (NWA Stn 30), 22 Sept. 2006, J.M. Huisman (PERTH 07720203).

\section{Family LIAGORACEAE}

GANONEMA Fan \& Wang, 1974: 492.

Ganonema pinnatum (Harvey) Huisman, 2002: 828. 
Liagora pinnata Harvey, 1853: 138. Type Locality: Sand Key, Florida, U.S.A. Illustrations: Huisman, 2002: Figures 125, 126, 128-130. Distribution: Widespread in tropical seas. Specimens: Mermaid Reef, Rowley Shoals, inner side of western reef in shallows (NWA Stn 6), 14 Sept. 2006, J.M. Huisman (PERTH 07788851). Mermaid Reef, Rowley Shoals, south outer, 14 Dec. 2007, J.M. Huisman (PERTH 07789408; PERTH 07789416). Scott Reef (South), west side of sandy islet (NWA Stn 24), 20 Sept. 2006, J.M. Huisman (PERTH 07720513).

Ganonema farinosum (Lamouroux) Fan \& Wang 1974: 492.

Liagora farinosa Lamouroux, 1816: 240. Type Locality: Red Sea, near Suez. Illustrations: Huisman, 2000: 30. Huisman, 2002: Figures 118-123. Distribution: Specimens: Scott Reef, lagoon bommie, (NWA Stn 25), 21 Sept. 2006, J.M. Huisman (PERTH 07788789).

\section{LIAGORA Lamouroux, 1812: 185.}

\section{Liagora ceranoides Lamouroux 1816: 239.}

Type Locality: St Thomas, Virgin Islands. Illustrations: Huisman, 2006: Figures 1F, 25A-D, plate 15. Distribution: Widespread in tropical and warmer seas. Generally epilithic in the subtidal, often with the base covered with sand. Specimens: Scott Reef (South) west side of sandy islet (NWA Stn 24), 20 Sept. 2006, J.M. Huisman (PERTH 07720238).

\section{TITANOPHYCUS Huisman, Saunders \& Sherwood, 2006b: 119.}

Titanophycus validus (Harvey) Huisman, Saunders \& Sherwood, 2006b: 119.

Liagora valida Harvey, 1853: 138. Type Locality: Sand Key, Florida, U.S.A. Illustrations: Huisman et al., 2006a: Figures 2B, 34, plate 17. Specimens: Scott Reef, intertidal reef adjacent to channel, (NWA Stn 33), 23 Sept. 2006, J.M. Huisman (PERTH 07816499).

\section{Order CORALLINALES \\ Family CORALLINACEAE}

AMPHIROA Lamouroux, 1812: 186.

Amphiroa fragilissima (Linnaeus) Lamouroux, 1816: 298.

Corallina fragilissima Linnaeus, 1758: 806. Type Locality: Jamaica. Illustrations: Huisman, 2000: 50. Distribution: Epilithic, generally in the shallow subtidal. Commonly found on reef flats.

\section{HYDROLITHON (Foslie) Foslie, 1909: 55.}

Hydrolithon farinosum (Lamouroux) Penrose \& Chamberlain, 1993: 295.
Melobesia farinosa Lamouroux, 1816: 315. Type Locality: Mediterranean Sea. Illustrations: Penrose, 1996: 260-261, figure 118. Huisman et al., 2007: 76. Distribution: Virtually cosmopolitan; epiphytic on a variety of other algae. Specimens: Scott Reef east of sand island, (URS Tr. 21), epiphytic on Caulerpa cupressoides, 19 Feb. 2006, J.M. Huisman (PERTH). Remarks: This small epiphyte occurs on a broad range of larger algae and is found throughout the atolls.

Hydrolithon gardineri (Foslie) Verheij \& Prud'homme van Reine 1993: 451 Lithophyllum gardineri Foslie 1907: 30-31.

Type Locality: Coetivy Reef, Seychelles. Distribution: Widespread in tropical Indo-Pacific. Illustrations: Littler \& Littler, 2003: 48-49 (as Porolithon gardineri). Specimens: Clerke Reef, Rowley Shoals, J.M.Huisman Clerke Reef, Rowley Shoals, southern lagoon, 11 Dec. 2007, J.M. Huisman (PERTH 07816685).

Hydrolithon onkodes (Heydrich) Penrose \& Woelkerling, 1992: 83 (Figure 2)

Lithothamnion onkodes Heydrich, 1897: 6. Type Locality: Tami Island, north-west edge of Huon Gulf, New Guinea. Illustrations: Littler \& Littler, 2003: 50-51 (as Porolithon onkodes). Distribution: Widespread in tropical seas. Specimens: Imperieuse Reef, Rowley Shoals, north-east slope, 2 Dec. 2007, J.M. Huisman (PERTH). Clerke Reef, Rowley Shoals, Mermaid Reef, 10 Dec. 2007, J.M. Huisman (PERTH 07816677). Scott Reef, southeast side, 18 Feb. 2006, J.M. Huisman (PERTH). Remarks: Hydrolithon onkodes is the common crustose coralline on reef crests in high energy zones.

Hydrolithon samoense (Foslie) Keats \& Chamberlain, 1994: 15-19, figures 31-54. Lithophyllum samoënse Foslie, 1906: 20.

Type locality: Satana, Savaii Island, Western Samoa. Illustrations: Keats \& Chamberlain, 1994: Figures 31-54. Distribution: Widespread in tropical to temperate seas. Specimens: Clerke Reef, Rowley Shoals, southern lagoon, 11 Dec. 2007, J.M. Huisman (PERTH 07816693).

\section{JANIA Lamouroux, 1812: 186.}

Jania adhaerens Lamouroux, 1816: 270.

Type Locality: "Méditerranée?" Illustrations: Price \& Scott, 1992: 48-50, figure 12A-C. Distribution: Widespread in tropical and subtropical seas. Specimens: Seringapatam Reef (NWA Stn 42), 26 Sept. 2006, J.M. Huisman (PERTH).

\section{LITHOPHYLLUM Philippi, 1837: 387.}


Lithophyllum kotschyanum Unger, 1858: 22, plate 5: Figures 15, 16

Type Locality: Bahrain. Illustrations: Adey et al., 1982: 37-40, figures 23-25. Huisman, 2000: 55. Distribution: Widespread in tropical waters of the Indian and Pacific Oceans. Specimens: Scott Reef (north), east side near channel (URS Tr. 27), 21 Feb. 2006, J.M. Huisman (PERTH).

Lithophyllum tamiense (Heydrich) Foslie, 1900a: 16.

Lithothamnion tamiense Heydrich, 1897: 1: Plate 1: Figures 4-7. Type Locality: Tami Island, Papua New Guinea. Illustrations: Ringeltaube \& Harvey, 2000: Figures 7-11. Distribution: Widespread in tropical waters of the Indian and Pacific Oceans. Specimens: Imperieuse Reef, Rowley Shoals, shallow lagoon, 6 Dec. 2007, J.M. Huisman (PERTH). Clerke Reef, Rowley Shoals, southern lagoon, 11 Dec. 2007, J.M. Huisman (PERTH 07816707).

\section{LITHOTHAMNION Heydrich, 1897: 412.}

\section{Lithothamnion proliferum Foslie, 1904: 18-19.}

Type Locality: Lumu-Lumu shoal (Pulau Lumulumu), Borneo Bank, Indonesia. Illustrations: Keats et al., 1996; Littler \& Littler, 2003: 38-39. Distribution: Tropical Indian and Pacific Oceans. Specimens: Scott Reef (NWA Stn 31), 23 Sept. 2006, J.M. Huisman (PERTH). Remarks: This species inhabits darker crevices in the reef and can usually be recognized by its broad, horizontal protuberances and smooth surface.

\section{RHIZOLAMELLIA Shevejko, 1982: 26}

Rhizolamellia collum Shevejko, 1982: 26-28. (Figure 6)

Type Locality: Scott Reef, Western Australia, 17-27 m depth. Illustrations: Shevejko, 1982: Figures 1, 2. Distribution: Apparently known only from Scott Reef. Specimens: Scott Reef (NWA Stn 28), 22 Sept. 2006, J.M. Huisman (PERTH). Scott Reef (NWA Stn 36), south of channel, 24 Sept. 2006, J.M. Huisman (PERTH). Remarks: Rhizolamellia is a monospecific genus described from collections made by a Russian expedition to Scott Reef in 1978 (Shevejko, 1982) and the present specimens are the first record of the species since its description. The taxonomic placement of the genus is considered questionable by Woelkerling (1988) and the specimens collected during these surveys are being studied in detail (including DNA sequencing). These results will be presented elsewhere. Rhizolamellia inhabits darker crevices in the reef where is forms fragile, basally attached crusts.

\section{Family SPOROLITHACEAE}

SPOROLITHON Heydrich, 1897: 66.

Sporolithon ptychoides Heydrich, 1897: 67-69, figures. 2, 3, plate III: Figures. 20-23.

Type Locality: El Tor, Sinai Peninsula, Egypt. Illustrations: Verheij \& Prud'homme van Reine, 1993; Littler \& Littler, 2003: 52-53. Distribution: Widespread in warmer waters of the Indo-Pacific and the Mediterranean. Specimens: Clerke Reef, Rowley Shoals, lagoon near channel at $12 \mathrm{~m}$ depth, 10 Dec. 2007, J.M. Huisman (PERTH).

\section{Order GELIDIALES \\ Family GELIDIACEAE}

GELIDIELLA Feldmann \& Hamel, 1934: 529.

Gelidiella acerosa (Forsskål) Feldmann \& Hamel, 1934: 533.

Fucus acerosus Forsskål, 1775: 190. Type Locality: Mocha, Yemen. Illustrations: Price \& Scott, 1992: 25-27, figure 4. Huisman, 2000: Specimens: Scott Reef (URS Tr. 2), intertidal, 16 Feb. 06, J.M. Huisman (PERTH 07816367).

\section{Family PTEROCLADIELLACEAE}

PTEROCLADIELLA Santelices \& Hommersand, 1997: 117.

Pterocladiella caerulescens (Kützing) Santelices \& Hommersand, 1997: 118.

Gelidium caerulescens Kützing, 1868: 19, pl 56, figures c-d. Type Locality: Wagap, New Caledonia. Illustrations: Price \& Scott, 1992: 21-24, figure 3AF. Santelices, 1976: 173, figures 1-27 (as Pterocladia caerulescens). Distribution: Warmer waters of the Indo-Pacific. Specimens: Scott Reef, channel (NWA Stn 40), 25 Sept. 2006, J.M. Huisman (PERTH).

\section{Order BONNEMAISONIALES \\ Family BONNEMAISONIACEAE \\ ASPARAGOPSIS Montagne, 1841: xv.} 45.

Asparagopsis taxiformis (Delile) Trevisan, 1845:

Fucus taxiformis Delile, 1813[1813-1826]: 151, 295, plate 57, figure 2. Type Locality: Alexandria, Egypt. Illustrations: Cribb, 1983: 28, plate 4, figures 1-2. Huisman, 2000: 47. Distribution: Cosmopolitan in warmer seas. Epilithic in the subtidal. Specimens: Mermaid Reef, Rowley Shoals, inner side of western reef, in shallows, (NWA Stn 6) 14 Sept. 2006, J.M. Huisman (PERTH 07816545). Remarks: Asparagopsis has a markedly heteromorphic life history and the present record is of the diminutive tetrasporophyte only. 


\section{Order GIGARTINALES}

\section{Family CORYNOCYSTACEAE}

CORYNOCYSTIS Kraft in Kraft et al., 1999: 26.

Corynocystis prostrata Kraft in Kraft et al., 1999: 26. (Figure 8)

Type Locality: Bulusan, Sorsogon Province, Philippines. Illustrations: Kraft et al., 1999: Figure 20. Distribution: Known from the Rowley Shoals and Scott Reef; otherwise seemingly widespread in the Indo-West Pacific. Plants are almost invariably found in deep, shaded recesses in coral reefs. Specimens: Cod Hole, Mermaid Reef, 15 Dec. 2007, J.M. Huisman (PERTH 07729308). Mermaid Reef, Rowley Shoals, lagoon entrance channel. (NWA Stn 13), 16 Sept. 2006, J.M. Huisman (PERTH 07720122). Remarks: This represents a new record for Western Australia.

\section{Family DUMONTIACEAE GIBSMITHIA Doty, 1963: 458.}

Gibsmithia hawaiiensis Doty, 1963: (Figure 9)

Type Locality: Waikiki, O’ahu, Hawaiian Islands. Illustrations: Doty, 1963: 458-465, figures 1-7. Kraft, 1986b: 425-433, figures 2-22. Huisman, 2000: 75. Huisman et al., 2007: 85. Distribution: Widespread in tropical waters of the Indo-West Pacific. Epilithic in the subtidal. Specimens: Mermaid Reef, Rowley Shoals, lagoon bommie at $12 \mathrm{~m}$ depth, 16 Sept. 2006, J.M. Huisman (PERTH).

\section{Family PEYSSONNELIACEAE}

PEYSSONNELIA Decaisne, 1841: 168.

Peyssonnelia inamoena Pilger, 1911: 311. (Figure 7)

Type Locality: Gross-Batanga, Cameroon, West Africa. Illustrations: Kawaguchi et al., 2002: Figures 23-29. Distribution: Tropical to warm temperate regions in the Atlantic, Pacific and Indian Oceans. Specimens: Imperieuse Reef, Rowley Shoals, 2 Dec. 2007, J.M. Huisman (PERTH 07789343). Scott Reef (NWA Stn 30) in cavities in reef, 22 Sept. 2006, J.M. Huisman (PERTH 07788819). Remarks: In addition to $P$. inamoena, several other species of Peyssonnelia were common at the atolls. These are presently being studied.

\section{Family RHIZOPHYLLIDACEAE}

\section{PORTIERIA Zanardini, 1851: 33.}

Portieria hornemannii (Lyngbye) Silva in Silva et al., 1987: 129.

Desmia hornemanniii Lyngbye, 1819: 35, plate 7c. Type Locality: Probably Red Sea.

Illustrations: Cribb, 1983: 35-36, plate 8, figure 2 (as Chondrococcus hornemannii). Huisman, 2000: 92. Distribution: Tropical Indo-Pacific. Epilithic in the lower intertidal and shallow subtidal. Specimens: Scott Reef (NWA Stn 22), 20 Sept. 2006, J.M. Huisman (PERTH).

\section{Family HYPNEACEAE}

HYPNEA Lamouroux, 1813: 131.

\section{Hypnea spp.}

Remarks: Small, fragmentary specimens of Hypnea were collected during the surveys but these were inadequate for species deterimination.

\section{Order NEMASTOMATALES \\ Family NEMASTOMATACEAE \\ PREDAEA De Toni f., 1936: [5]}

Predaea laciniosa Kraft, 1984: 11-15.

Type locality: Coral Gardens, Heron Island, Great Barrier Reef, Australia. Illustrations: Kraft, 1984: Figures 25-35. Distribution: Warmer waters of the Indo-Pacific. Specimens: Scott Reef (NWA Stn 31), 23 Sept. 2006, J.M. Huisman (PERTH 07816391).

\section{Predaea weldii Kraft \& Abbott 1971: 194.}

Type Locality: Kãne'ohe Bay, O’ahu, Hawaiian Islands. Illustrations: Kraft, 1984: 15-19, figures 36-42; Huisman, 2000: 85. Distribution: Widely distributed in tropical seas. Specimens: Mermaid Reef, Rowley Shoals, lagoon bommie at $12 \mathrm{~m}$ depth, 16 Sept. 2006, J.M. Huisman (PERTH).

\section{Family SCHIZYMENIACEAE}

PLATOMA Schousboe ex Schmitz, 1894: 627.

Platoma cyclocolpum (Montagne) Schmitz, 1894: 627 (footnote), 628.

Halymenia cyclocolpa Montagne, 1841: 163-164. Type Locality: Teneriffe, Canary Islands. Illustrations: Huisman, 1999: Figures 1-12; Huisman, 2000: 84. Specimens: Mermaid Reef, Rowley Shoals, south end of lagoon at $20 \mathrm{~m}$ depth (NWA Stn 26), 21 Sept. 2006, J.M. Huisman (PERTH 07720114).

\section{TITANOPHORA (J.Agardh) J. Feldmann, 1942:} 111.

Titanophora pikeana (Dickie) Feldmann, 1942: 111.

Galaxaura pikeana Dickie, 1874: 195-196. Type Locality: Mauritius. Illustrations: Børgesen, 1943: Figure 13. Huisman, 2000: 86; Schils \& Coppejans, 2002: Figures 36-44. Distribution: Known from the Houtman Abrolhos, Western Australia, presumably around northern Australia to Queensland and Lord Howe I., N.S.W. Tropical Indo-Pacific. Epilithic in 
the subtidal, usually associated with coral reefs. Specimens: Seringapatam Reef (NWA Stn 43), 26 Sept. 2006, J.M. Huisman (PERTH 07719000). Remarks: Previously reported as Titanophora weberae Børgesen (type locality: Salee Strait, Irian Barat, Indonesia), a species now considered synonymous.

\section{Order RHODYMENIALES Family CHAMPIACEAE \\ CHAMPIA Desvaux, 1809: 245.}

Champia parvula (C.Agardh) Harvey, 1853: 76.

Chondria parvula C.Agardh, 1824: 207. Type Locality: Cádiz, Spain. Illustrations: Price \& Scott, 1992: 55-57, figure 14A-E. Huisman, 2000: 109. Distribution: Widespread in tropical and temperate seas. Specimens: Scott Reef (NWA Stn 31), 23 Sept. 2006, J.M. Huisman (PERTH)

\section{Family RHODYMENIACEAE}

\section{ASTEROMENIA Huisman \& Millar, 1996: 138.}

\section{Asteromenia sp.}

Specimens: Mermaid reef, Rowley Shoals, outside slope middle east side, 13 Sept. 2006, J.M. Huisman (PERTH 07626339). Remarks: The genus Asteromenia was recently monographed by Saunders et al., (2006), a study that included DNA sequencing and included specimens from Western Australia. The Rowley Shoals entity has been sequenced and compared with known species (see Saunders et al.), and these results, plus morphological observations, indicate it to be a new species (Saunders, pers. comm.) It will be described formally elsewhere.

\section{CERATODICTYON Zanardini, 1878: 36.}

Ceratodictyon spongiosum Zanardini, 1878: 37.

Type Locality: Wokam, Aru Islands, Indonesia. Illustrations: Price \& Kraft, 1991: Figures 1-16. Huisman, 2000: 115. Distribution: Widespread in the tropical Indo-Pacific. In Western Australia, from the tropics south to the Houtman Abrolhos. Epilithic in the intertidal and shallow subtidal. Specimens: Scott Reef (South), intertidal reef flat, 19 Feb. 2006, J.M. Huisman (PERTH 07725523).

\section{CHAMAEBOTRYS Huisman, 1996: 105.}

Chamaebotrys boergesenii (Weber-van Bosse) Huisman, 1996: 105.

Coelarthrum boergesenii Weber-van Bosse, 1928:473, figures. 207, 208. Type Locality: Sailus-Besar, Isles Paternoster, from $27 \mathrm{~m}$ depth. Illustrations: Huisman, 1996: 105-109, figures 35-38, 40-42. Huisman, 2000: 116. Distribution: Widespread in warmer waters. Generally found in protected positions on and under rock and coral ledges. Specimens: Imperieuse Reef, Rowley Shoals, east side, 5 Dec. 2007, J.M. Huisman (PERTH).

\section{COELOTHRIX Børgesen, 1920: 389.}

Coelothrix irregularis (Harvey) Børgesen, 1920: 389 , figures 373, 374.

Cordylecladia irregularis Harvey, 1853: 156. Type Locality: Key West, Florida, U.S.A. Illustrations: Price \& Scott, 1992: Figure 17A-D. Huisman, 2000: 110. Distribution: Widespread in the tropical Indo-West Pacific region and tropical West Atlantic Ocean. Specimens: Mermaid Reef, Rowley Shoals, inner side of western reef in shallows (NWA Stn 6), 14 Sept. 2006, J.M. Huisman (PERTH 07788878). Scott Reef (South), reef flat (URS Tr. 12), 18 Feb. 2006, J.M. Huisman (PERTH 07724640).

\section{GELIDIOPSIS Schmitz, 1895: 148.}

Gelidiopsis intricata (C.Agardh) Vickers, 1905: 61.

Sphaerococcus intricatus C.Agardh, 1822: 333334. Type Locality: Mauritius, Hawaiian Islands, and Ravak (Rauki I., near Waigeo I, Indonesia) (lectotype needs selecting). Illustrations: Price \& Scott, 1992: Figure 13a-f. Distribution: Widespread in the tropical seas. Specimens: Imperieuse Reef, Rowley Shoals, 6 Dec. 2007, J.M. Huisman (PERTH 07729367). Mermaid Reef, Rowley Shoals, inner side of western reef, in shallows (NWA Stn 6), 14 Sept. 2006, J.M. Huisman (PERTH 07788886).

\section{Order CERAMIALES \\ Family CERAMIACEAE}

AGLAOTHAMNION Feldmann-Mazoyer, 1941: 17.

Aglaothamnion cordatum (Børgesen) FeldmannMazoyer, 1941: 459.

Callithamnion cordatum Børgesen, 1909: 10-11, figures. 5-6. Type Locality: Off Cruz bay, between St. Thomas and St. Jan, Virgin Islands. Illustrations: Price \& Scott, 1992: 75-76, figure 22A, B. Huisman, 2000: 27. Distribution: Widespread in tropical seas. Specimens: Mermaid Reef, Rowley Shoals, lagoon bommie near south tip of reef (NWA Stn 14), epiphytic on Dictyota sp. 16 Sept. 2006, J.M. Huisman (PERTH 07816421).

\section{ANOTRICHIUM Nägeli, 1862: 397}

Anotrichium tenue (C.Agardh) Nägeli, 1862: 399.

Griffithsia tenuis C.Agardh, 1828: 131. Type Locality: Venezia, Italy. Illustrations: Baldock, 1976: Figures 59-64, 90. Huisman, 2000: 129. Distribution: Widely distributed in all tropical and subtropical oceans except for the eastern Atlantic. Epilithic and 
epiphytic on a variety of algae and seagrasses. Specimens: Mermaid Reef, Rowley Shoals (NWA Stn 14), on Thalassia hemprichii, 16 Sept 2006, J.M. Huisman (PERTH).

\section{ANTITHAMNION Nägeli, 1847: 202.}

Antithamnion antillanum Børgesen, 1917: 226, figures 213-216.

Type Locality: In the Harbour near Charlotte Amalia, St. Thomas, Virgin Is. Illustrations: Price \& Scott, 1992: 69-72, figure 20A-C. Distribution: Widespread in tropical seas. Specimens: Scott Reef (South), north east outer slope (NWA Stn 30), 22 Sept. 2006, J.M. Huisman (PERTH 07816405).

\section{ANTITHAMNIONELLA Lyle, 1922: 347.}

\section{Antithamnionella sp.}

Specimens: Scott Reef (South), north east outer slope (NWA Stn 30), 22 Sept. 2006, J.M. Huisman (PERTH 07816626; also with PERTH 07816405). Remarks: These specimens do not fit any of the presently recognized species and appear to represent a new species. It will be described formally elsewhere.

\section{BALLIELLA Itono \& Tanaka, 1973: 249.}

Balliella subcorticata (Itono) Itono \& Tanaka, 1973: 250.

Antithamnion subcorticatum Itono, 1969: 40, figure 7. Type Locality: Yoronjima, Okinawa-gunto, Ruykyu-retto, Japan. Illustrations: Itono \& Tanaka, 1973: Figures 1, 2, 18-22. Distribution: Probably widespread in the Indo-West Pacific; in Australia known only from the present collection and the Dampier Archipelago (Huisman \& Borowitzka, 2003); epiltihic or epiphytic in the subtidal. Specimens: Cod Hole, Mermaid Reef, Rowley Shoals, epiphytic on Corynocystis prostrata, 15 Dec. 2007, J.M. Huisman (PERTH 07816618).

\section{CENTROCERAS Kützing, 1841: 731.}

Centroceras clavulatum (C.Agardh) Montagne, 1846: 140.

Ceramium clavulatum C. Agardh, 1822: 2. Type Locality: Callao, Peru. Illustrations: Price \& Scott, 1992: 81-82, figure 25A-E; Huisman, 2000: 134. Distribution: Widespread in warmer waters; epilithic or epiphytic on a variety of substrata, very common. Specimens: Mermaid Reef, Rowley Shoals, lagoon (NWA Stn 1), on Stypopodium flabelliforme, 12 Sept. 2006, J.M. Huisman (PERTH 07816537). Scott Reef (South), entrance to false lagoon (NWA Stn 25), epiphytic on Dictyota sp., 21 Sept. 2006, J.M. Huisman (PERTH).

\section{CERAMIUM Roth, 1797: 146}

Ceramium codii (Richards) Mazoyer, 1938: 324.

Ceramothamnion codii Richards, 1901: 264, pls. 21-22. Type Locality: Bermuda, epiphytic on Codium. Illustrations: South \& Skelton, 2000: Figures 11-14. Distribution: Widespread in warmer seas. Specimens: Mermaid Reef, Rowley Shoals, (NWA Stn 7), 16 Sept. 2006, J.M. Huisman (PERTH 07816480).

Ceramiun krameri South \& Skelton, 2000: 69.

Type Locality: Sawa-I-lau, Fiji. Illustrations: South \& Skelton, 2000: Figures 45-51. Distribution: Fiji, Samoa, north-western Australia. Specimens: Scott Reef, channel (NWA Stn 40), 25 Sept. 2006, J.M. Huisman (with PERTH 07816413).

Ceramium macilentum J.Agardh, 1894: 15.

Type Locality: Port Phillip, Victoria, Australia. Illustrations: South \& Skelton, 2000: Figures 52-62. Distribution: Widespread in tropical and temperate seas. Specimens: Clerke Reef, Rowley Shoals, epiphytic on Actinotrichia fragilis, 11 Dec. 2007, J.M. Huisman (PERTH 07816596).

Ceramiun vagans Silva, in Silva et al., 1987: 56.

Type Locality: Parry I., Eniwetok Atoll, Marshall Islands. Illustrations: South \& Skelton, 2000: Figures 89-93. Distribution: Widespread in the tropics. Specimens: Scott Reef, channel (NWA Stn 40), 25 Sept. 2006, J.M. Huisman (PERTH 07816413). Remarks: This represents a new record for Western Australia

\section{CORALLOPHILA Weber-van Bosse 1923: 339.}

Corallophila apiculata (Yamada) R.Norris, 1993: 395.

Centroceras apiculatum Yamada, 1944: 42. Type Locality: Ant Atoll, Senyavin Is., East Caroline Is. Illustrations: Price \& Scott, 1992: Figures 24A-D (as Centroceras apiculatum). Distribution: Tropical regions of the Indo-Pacific; in WA also known from Barrow Island and the Dampier Archipelago (Huisman \& Borowitzka, 2003). Specimens: Mermaid Reef, Rowley Shoals, lagoon bommie near south tip of reef (NWA Stn 14), 16 Sept. 2006, J.M. Huisman (PERTH). Scott Reef (South), north east outer slope (NWA Stn 30), 22 Sept. 2006, J.M. Huisman (PERTH 07816456).

\section{CROUANIA J.Agardh, 1842: 83.} 83.

Crouania attenuata (C.Agardh) J.Agardh, 1842:

Mesogloia attenuata C.Agardh, 1824: 51. Type Locality: "In mari Atlantico" Illustrations: Price \& Scott, 1992: 117-120, figure 38A-D, 39A-B. Distribution: Widespread in temperate and tropical seas. Epiphytic and epilithic in intertidal regions. 
Specimens: Mermaid Reef, Rowley Shoals, inner side of western reef (NWA Stn 6), on Codium sp., 14 Sept. 2006, J.M. Huisman (PERTH 07816588).

\section{GAYLIELLA Cho, McIvor \& Boo, in Cho et al., 2008: 723.}

Gayliella flaccida (Harvey ex Kützing) Cho \& McIvor in Cho et al., 2008: 723

Hormoceras flaccidum Harvey ex Kützing, 1862: 21, plate 69a-d. Type Locality: Kilkee, County Clare, Eire. Illustrations: Womersley, 1978: 234, figures 4A-D, 14E-H; Huisman, 2000: 135 (as Ceramium flaccidum). Distribution: Widely distributed in cool-temperate to tropical oceans. Epiphytic on a variety of larger algae and seagrasses. Specimens: Mermaid Reef, Rowley Shoals, inner side of western reef (NWA Stn 6), on Codium sp., 14 Sept. 2006, J.M. Huisman (PERTH). Remarks: This species is more commonly known as Ceramium flaccidum (Harvey ex Kützing) Ardissone, but was recently transferred to the new genus Gayliella following a DNA sequence study (Cho et al., 2008).

\section{GRIFFITHSIA C.Agardh, 1817: xxviii.}

Griffithsia heteromorpha Kützing, 1863: 2, plate 3: Figures. a, b.

Type Locality: New Caledonia. Illustrations: Price \& Scott, 1992: 121-123, figure 40A-B. Distribution: Tropical Indo-West Pacific region and tropical western Atlantic Ocean. Specimens: Scott Reef (South), entrance to false lagoon (NWA Stn 25), 21 Sept. 2006, J.M. Huisman (PERTH 07816634). Remarks: The specimens are tetrasporangial and with non-involucrate sporangia, as is typical of this species.

\section{HALOPLEGMA Montagne, 1842: 258.}

Haloplegma duperreyi Montagne, 1842: 258-261, plate 7 , figure 1 .

Type Locality: Martinique, West Indies. Illustrations: Womersley, 1998: Figure 133. Distribution: Widespread in tropical seas; epilithic. Specimens: Seringapatam Reef, south side outer slope at $20 \mathrm{~m}$ depth (NWA Stn 41), 26 Sept. 2006, J.M. Huisman (PERTH 07720378).

\section{SEIROSPORA Harvey, 1846: 1, t. XXI.1}

Seirospora orientalis Kraft, 1988: 2.

Type Locality: One Tree Island, Capricorn Group, Great Barrier Reef, Queensland, Australia. Illustrations: Kraft, 1988: 1-11, figures 2-25. Huisman, 2000: 143. Distribution: Known from the Capricorn Group, Queensland, and the Houtman Abrolhos to Scott Reef, Western Australia. Specimens: Scott
Reef (South), entrance to false lagoon (NWA Stn 25), epiphytic on Padina sp., 21 Sept. 2006, J.M. Huisman (PERTH 07816642).

\section{SPYRIDIA Harvey, 1833: 259.}

Spyridia filamentosa (Wulfen) Harvey, 1833: 337

Fucus filamentosus Wulfen, 1803: 64. Type Locality: Adriatic Sea. Illustrations: Womersley \& Cartledge, 1975: 222, figures 1, 3A, B; Huisman, 2000: 145. Distribution: Widely distributed in tropical and warm temperate oceans; epilithic or epiphytic in the intertidal and subtidal. Specimens: Scott Reef, reef flat (NWA Stn 27), 21 Sept. 2006, J.M. Huisman (PERTH). Seringapatam Reef, on lagoon edge of reef flat at $10 \mathrm{~m}$ depth (NWA Stn 42), 26 Sept. 2006, J.M. Huisman (PERTH 07816529).

\section{TIFFANIELLA Doty \& Meñez, 1960: 135.}

Tiffaniella cymodoceae (Børgesen) Gordon, 1972: 121.

Spermothamnion cymodoceae Børgesen, 1952: 54, figures 27, 28. Type Locality: Riambel, Mauritius. Illustrations: Gordon, 1972: Figures 39D-F, 40AE. Womersley, 1998: Figure 100A-D. Distribution: Indian Ocean. Specimens: Scott Reef (NWA Stn 30), on Galaxaura sp., 22 Sept. 2006, J.M. Huisman (PERTH 07816561). Remarks: The present specimens were growing amongst the surface filaments of Actinotrichia fragilis. The only reproductive structures seen were tetrasporangia, so the identification is tentative.

\section{Family DASYACEAE}

HETEROSIPHONIA Montagne, 1842: 4.

Heterosiphonia crispella (C.Agardh) Wynne, 1985: 87.

Callithamnion crispella C.Agardh, 1828: 183. Type Locality: near Cádiz, Spain. Illustrations: Cribb, 1983: 105, plate 64, figure 1 (as Heterosiphonia wurdemanni var. laxa). Distribution: Most tropical oceans, previously recorded for Western Australia at the Dampier Archipelago (Huisman \& Borowitzka, 2003). Specimens: Scott Reef, channel (NWA Stn 40), 25 Sept. 2006, J.M. Huisman (PERTH 07816472).

\section{Family DELESSERIACEAE}

ZELLERA Martens, 1866: 33.

Zellera tawallina Martens, 1866: 33, plate VIII: Figure 3.

Type Locality: 'Klein Tawalli" [Tawaliketjil] I., Halmahera, Indonesia. Illustrations: Verheij and Prud'homme van Reine, 1993: 443, plate 14, figure 8; Millar et al., 1999: 570, figure 6A. Distribution: Widespread in tropical regions of the eastern 
Indian and western Pacific Oceans, although seemingly never abundant. Specimens: Scott Reef (NWA Stn 31), 23 Sept. 2006, J.M. Huisman (PERTH 07788797). Scott Reef, channel (NWA Stn 40), 25 Sept. 2006, J.M. Huisman (PERTH 07718799).

\section{Family RHODOMELACEAE}

ACANTHOPHORA Lamouroux, 1813: 132.

Acanthophora spicifera (Vahl) Børgesen, 1910: 201.

Fucus spiciferus Vahl, 1802: 44. Type Locality: St. Croix, Virgin Islands. Illustrations: Cribb, 1983: 105-106, plate 32, figure 2. Huisman, 2000: 154. Distribution: Widespread in tropical and warmer seas; in Western Australia south to Dawesville. Specimens: Mermaid Reef, Rowley Shoals, inner platform, west side, 14 Sept. 2006, J.M. Huisman, (PERTH 07626533). Mermaid Reef, Rowley Shoals, inner lagoon, east side, 12 Sept. 2006, J.M. Huisman (PERTH 07719035). Mermaid Reef, Rowley Shoals, 16 Dec. 2007, J.M. Huisman (PERTH 07729081).

\section{HERPOSIPHONIA Nägeli, 1846: 238.}

Herposiphonia secunda (C.Agardh) Ambronn, 1880: 197.

Hutchinsia secunda C.Agardh, 1824: 149. Type Locality: Sicily, Mediterranean. Illustrations: Millar, 1990: 451-452, figures 68A-C. Huisman, 2000: 168. Distribution: Widespread in warmer waters. Epiphytic on a variety of larger algae and seagrasses. Specimens: Seringapatam Reef (NWA Stn 42), on Hypnea, 26 Sept. 2006, J.M. Huisman (PERTH).

\section{LEVEILLEA Decaisne, 1839: 375.}

Leveillea jungermannioides (Hering \& G.Martens) Harvey, 1855: 539.

Amansia jungermannioides Hering \& G.Martens in G.Martens \& Hering, 1836: 485. Type Locality: Tor, Sinai Peninsula, Egypt. Illustrations: Price \& Scott, 1992: 196-198, figure 71A, B. Huisman, 2000: 173. Distribution: Widely distributed in tropical and subtropical Indo-west Pacific. Epiphytic on a variety of larger algae and seagrasses. Specimens: Scott Reef (South) west side of sandy islet (NWA Stn 24), 20 Sept. 2006, J.M. Huisman (PERTH 07816448).

\section{NEOSIPHONIA Kim \& Lee, 1999: 271-281.}

Neosiphonia poko (Hollenberg) Abbott in Abbott et al., 2002: 312

Polysiphonia poko Hollenberg, 1968: 70, figures 3A, 15. Type Locality: Near reef margin, north of North Island, Johnston Atoll. Illustration: Hollenberg, 1968, figures 3A, 15. Distribution: Probably warmer waters of the Indo-Pacific. Specimen: Scott Reef, channel (NWA Stn 40), 25 Sept. 2006, J.M. Huisman (PERTH).

\section{POLYSIPHONIA Greville, 1823: 90}

\section{Polysiphonia spp.}

Remarks: Several species of Polysiphonia were collected during the surveys but these were mostly fragmentary and inadequate for species deterimination.

\section{TOLYPIOCLADIA Schmitz in Engler \& Prantl, 1897: 441.}

Tolypiocladia glomerulata (C.Agardh) Schmitz, 1897: 442.

Hutchinsia glomerulata C.Agardh, 1824: 158. Type Locality: Shark Bay, Western Australia. Illustrations: Price \& Scott, 1992: 219-221, figure 81A-D. Huisman, 2000: 179. Distribution: Widely distributed in tropical Indo-west Pacific. Specimens: Scott Reef (South), entrance to false lagoon (NWA Stn 25), associated with Dictyota friabilis, 21 Sept. 2006, J.M. Huisman (PERTH 07725507). Seringapatam Reef, on lagoon edge of reef flat at $10 \mathrm{~m}$ depth (NWA Stn 42), 26 Sept. 2006, J.M. Huisman (PERTH).

\section{Family SARCOMENIACEAE}

\section{PLATYSIPHONIA Børgesen, 1931: 28.}

Platysiphonia delicata (Clemente y Rubio) Cremades in Cremades \& Perez-Cirera, 1990: 492. Conferva delicata Clemente y Rubio, 1807: 322. Type Locality: Sanlúcar de Barrameda, Cádiz, Spain. Illustrations: Børgesen, 1931: 21-29, figures 1-5; Ballantine \& Wynne, 1985: 461-463, figures 7, 8 [as Platysiphonia miniata (C. Agardh) Børgesen]. Distribution: Widely distributed. Specimens: Scott Reef (South), entrance to false lagoon (NWA Stn 25), 21 Sept. 2006, J.M. Huisman (PERTH 07816553).

\section{Order PIHIELLALES}

\section{Family PIHIELLACEAE}

PIHIELLA Huisman, Sherwood \& Abbott, 2003: 981.

Pihiella liagoraciphila Huisman, Sherwood \& Abbott, 2003: 981.

Type Locality: Mokulēia, O'ahu, Hawaiian Islands, on Titanophycus validus (Harvey) Huisman et al., Illustrations: Huisman et al., 2003: Figures 1-3. Distribution: Widespread in tropical seas; epiphytic or endophytic in Liagoraceae. Specimens: Scott Reef (South) west side of sandy islet (NWA Stn 24), endophytic in Liagora ceranoides, 20 Sept. 2006, J.M. Huisman (PERTH 07720238). Remarks: Pihiella liagoraciphila is a minute (generally less than 500 
$\mu \mathrm{m}$ in diameter) endophyte found in red algae of the family Liagoraceae. It is the only member of the order Pihiellales.

\section{Cyanobacteria (Blue-green Algae) \\ Family OSCILLATORIACEAE}

LYNGBYA C.Agardh ex Gomont, 1892: 95, 118.

Lyngbya majuscula (Dillwyn) Harvey, 1833: 370

Conferva majuscula Dillwyn, 1809: plate 20. Type Locality: England. Illustrations: Huisman et al., 2007: Distribution: Widespread in most seas. Specimens: Scott Reef (URS Tr. 2), intertidal, 16 Feb. 06, J.M. Huisman (PERTH 07816375).

\section{Family PHORMIDIACEAE}

SYMPLOCA Kützing ex Gomont, 1892: 104.

Symploca hydnoides (Harvey) Kützing, 1849: 272.

Calothrix hydnoides Harvey, 1833: 368-369. Type Locality: Appin, Argyll, Scotland. Illustrations: Littler \& Littler, 2000: 462, 463. Distribution: Cosmopolitan. Specimens: Scott Reef (South), intertidal near Guano wreck, 16 Feb. 2006, J.M. Huisman (PERTH 07720289).

\section{LEPTOLYNGBYA Anagnostidis \& Komárek, 1988:} 390.

Leptolyngbya crosbyana (Tilden) Anagnostidis \& Komárek, 1988: 391.

Phormidium crosbyanum Tilden, 1909: 645. Type Locality: Waianae, Oahu, Hawaiian Islands. Illustrations: Huisman et al., 2007: 41. Distribution: Widespread in tropical seas. Specimens: Imperieuse Reef, Rowley Shoals, 4 Dec. 2007, J.M. Huisman (PERTH 07789238). Scott Reef (NWA Stn 30), 22 Sept. 2006, J.M. Huisman (PERTH 07719132). Remarks: This species forms distinctive cartilaginous hummocks on rock.

\section{Magnoliophyta (Sea Grasses) \\ Order HYDROCHARITALES}

\section{Family HYDROCHARITACEAE}

THALASSIA Banks ex König, 1805 ('1806'): 96.

Thalassia hemprichii (Ehrenberg) Ascherson, 1871: 242. (Figure 13)

Schizotheca hemprichii Ehrenberg, 1832: 429. Type Locality: Massawa, Eritrea. Illustrations: Hartog, 1970: Figure 61, pls 25-27. Phillips \& Meñez, 1988: 68, figure 42. Distribution: Widespread in the IndoWest Pacific. Specimens: Mermaid Reef, Rowley Shoals, $\mathrm{S}$ end of inner lagoon at $11.9 \mathrm{~m}$ depth (NWA Stn 14) 16 September 2006, J.M. Huisman (PERTH 07725116). Mermaid Reef, Rowley Shoals, 16 Dec.
2007, J.M. Huisman (PERTH 07729103).

\section{HALOPHILA Thouars, 1806: 2.}

Halophila ovalis (R.Brown) Hook. f., 1858: 45.

Caulinia ovalis R.Brown, 1810: 339. Type Locality: Queensland, Australia.

Illustrations: Robertson, 1984: 61, figures 10B, C, 11D-G. Huisman, 2000: 283. Distribution: Widely distributed in tropical and warm temperate waters of the Indo-Pacific; growing in sand. Specimens: Imperieuse Reef, Rowley Shoals, lagoon, 4 Dec. 2007, J.M. Huisman (PERTH 07789289). Mermaid Reef, Rowley Shoals, inner lagoon bommie on west side at $11.3 \mathrm{~m}$ (NWA Stn 7), 14 Sept. 2006, J.M. Huisman (PERTH 07720386). Mermaid Reef, Rowley Shoals, lagoon near channel entrance, 14 Dec. 2007, J.M. Huisman (PERTH 07729146).

\section{Halophila decipiens Ostenfeld, 1902: 260.}

Type Locality: "Off Koh Kahdat, in 5 fathoms water (coral-sand)" [Gulf of Thailand]. Illustrations: Robertson, 1984: 61, figures 10A, 11A-C. Huisman, 2000: 283. Distribution: Widely distributed in tropical seas; growing in sand. Specimens: Scott Reef, lagoon bommie (NWA Stn 26), 21 Sept. 2006, J.M. Huisman (PERTH 07788908). Scott Reef (North), south-east corner at $20 \mathrm{~m}$ depth (NWA Stn 34), 24 Sept. 2006, J.M. Huisman (PERTH 07725221). Remarks: The local plants of $H$. decipiens tended to be smaller than $H$. ovalis, but positive identification can only be made by confirming the presence of marginal and surface spines. H. ovalis lacks spines.

\section{Order POTAMOGETONALES}

Family CYMODOCEACEAE

\section{THALASSODENDRON Hartog, 1970: 186.}

Thalassodendron ciliatum (Forsskål) Hartog, 1970: 186.

Zostera ciliata Forsskål, 1775: 157. Type Locality: Al Mukha, Yemen, southern Red Sea, leg. P. Forsskål, in BM (see den Hartog, 1970, p. 183). Illustrations: Hartog, 1970: Figure 52. Waycott et al., 2004: unnumbered Figures on p. 34. Distribution: Warm waters of Indo-West Pacific. Specimens: Not collected in the present survey but recorded from Scott Reef and the Rowley Shoals by Walker \& Prince (1987).

\section{ACKNOWLEDGEMENTS}

Sincere thanks to the various agencies/companies that supported the field work, including Woodside Energy, the WA Museum, the Western Australian Department of Environment and Conservation, and the Australian Institute of Marine Sciences. JMH also acknowledges the financial support of the 
Australian Biological Resources Study. Thanks also to the co-expeditioners and dive buddies, including Rob Hilliard (URS), Clay Bryce and Cory Whissen (WA Museum), Suzanne Long (DEC) and Katharina Fabricious (AIMS), and particular thanks to Clay for pulling it all together.

\section{REFERENCES}

Abbott, I.A., Fisher, J. and McDermid, K.J. (2002). New reported and revised marine algae from the vicinity of Nha Trang, Vietnam. In: Abbott, I.A. and McDermid, K.J. (eds), Taxonomy of Economic Seaweeds with reference to some Pacific species. Vol. VIII: 291-321. Oceanographic Institute, Nha Trang, Vietnam; California Sea Grant College.

Adey, W.H., Townsend R.A., and Boykins, W.T. (1982). The crustose coralline algae (Rhodophyta: Corallinaceae) of the Hawaiian Islands. Smithsonian Contributions to the Marine Sciences 15: 1-72.

Agardh, C.A. (1817). Synopsis algarum Scandinaviae. Berling, Lund. $x \mathrm{l}+135 \mathrm{p}$.

Agardh, C.A. (1822). Species algarum. Vol. 1, part 2, fasc. 1: v-vi + 169-398. Berling, Lund.

Agardh, C.A. (1822). Algae, Agardh. In: Kunth, C.S. Synopsis plantarum, quas, in itinere ad plagam aequinoctialem orbis novi, collegerunt Al. de Humbolt et Am. Bonpland. Vol 1: 1-6. Paris.

Agardh, C.A. (1822-1823). Species algarum. Vol. 1, part 2: i-viii, 169-398 (1822), 399-531(1823). Lund.

Agardh, C.A. (1824). Systema algarum. Literis Berlingianis, Lund. xxxviii $+312 \mathrm{p}$.

Agardh, C.A. (1828). Species algarum. Vol. 2, sect. 1. Moritz, Greifswald. lxxvi, + 189 p.

Agardh, J.G. (1837). Novae species algarum, quas in itinere ad oras maris Rubri collegit Eduardus Rüppell; cum observationibus nonnullis in species rariores antea cognitas. Museum Senckenbergianum 2: 169-174.

Agardh, J.G. (1842). Algae maris Mediterranei et Adriatici, observationes in diagnosin specierum et dispositionem generum. Masson \& Co., Paris.

Agardh, J.G. (1847). Nya alger från Mexico. Öfversigt af Kongl. [Svenska] Vetenskaps-Akademiens Förhandlingar 4: 5-17.

Agardh, J.G. (1848). Species, genera et ordines algarum. Volumen primum: algas fucoideas complectens. Gleerup, Lund. viii + 363 p.

Agardh, J.G. (1887). Till algernes systematik. Nya bidrag (Femte afdelningen). Lunds Universitets Årsskrift, Afdelningen för Mathematik och Naturvetenskap 23: 1-174, pls 1-5.

Agardh, J.G. (1894). Analecta algologica. Continuatio I. Lunds Universitets Årsskrift, Andra Afdelningen, Kongliga Fysiografiska Sällskapets i Lund Handlingar 29: 1-144, pls 1, 2.

Allender, B.M. and Kraft, G.T. (1983). The marine algae of Lord Howe Island (New South Wales): the Dictyotales and Cutleriales (Phaeophyta). Brunonia 6: 73-130.

Ambronn, H. (1880). Ueber einige Fälle von Bilateralität bei den Florideen. Botanische Zeitung 38: 161-174, 177-185, 193-200, 209-216, 225-233.
Anagnostidis, K. and Komárek, J. (1988). Modern approach to the classification system of cyanophytes. 3. Oscillatoriales. Archiv für Hydrobiologie, Supplement 80: 327-472, 35 Figures, 13 tables.

Ardissone, F. (1871). Revista dei Ceramii della flora Italiana. Nuovo Giorniale Botanico Italiano 3: 32-50.

Ascherson, P. (1871). Die Geographische Verbreitung der Seegräser. In: Mittheilungen aus Justus PERTHe's Geographischer anstalt über wichtige neue Erforschungen auf dem Gesammtgebiete der Geographie van Dr A. Petermann 1871, vol. 17. Justus Perthes, Gotha.

Askenasy, E. (1888). Algen. In: Forschungsreise S.M.S. 'Gazelle,' in den jahren 1874 bis 1876: IV Theil: Botanik: 1-58, pls 1-12. Mittler \& Son, Berlin.

Baldock, R.N. (1976). The Griffithsieae group of the Ceramiaceae (Rhodophyta) and its southern Australian representatives. Australian Journal of Botany 24: 509-593.

Ballantine, D. L. and Wynne, M. J. (1985). Platysiphonia and Apoglossum (Delesseriaceae, Rhodophyta) in the tropical western Atlantic. Phycologia 24: 459-465.

Børgesen, F. (1905). Contributions à la connaissance du genre Siphonocladus Schmitz. Oversight Over Det Kgl Danske Videnskabernes Selskabs Forhandlingar 3: 259-291.

Børgesen, F. (1909). Some new or little known West Indian Florideae. Botanisk Tidsskrift 30: 1-19, pls. I, II.

Børgesen, F. (1910). Some new or little known West Indian Florideae. II. Botanisk Tidsskrift 30: 177-207, 20 Figures.

Børgesen, F. (1914). The Marine Algae of the Danish West Indies. Vol. 1, pt 2: Phaeophyceae. Dansk Botanisk Arkiv 2: 157-226.

Børgesen, F. (1917). The marine algae of the Danish West Indies. Part 3. Rhodophyceae (3). Dansk Botanisk Arkiv 3: $145-240$.

Børgesen, F. (1920). The Marine Algae of the Danish West Indies, Part 3: Rhodophyceae (6), with Addenda to the Chlorophyceae, Phaeophyceae, and Rhodophyceae. Dansk Botanisk Arkiv 3: 369-498.

Børgesen, F. (1924). Marine algae from Easter Island. In: Skottsberg, C. (ed.) The Natural History of Juan Fernandez and Easter Island. Vol. 2: 247-309. Uppsala.

Børgesen, F. (1931). Sur Platysiphonia nov. gen. et sur les organes mâles et femelles du Platysiphonia miniata (Ag.) nov. comb. (Sarcomenia miniata (Ag.) J. Ag.). In: Recueil de Trav. Cryptog. dédiés à Louis Mangin: 21-29. Paris.

Børgesen, F. (1932). A revision of Forsskål's algae mentioned in Flora Aegyptiaco-Arabica and found in his herbarium in the Botanical Museum of the University of Copenhagen. Dansk Botanisk Arkiv 8: 14pp.

Børgesen, F. (1943). Some Marine Algae from Mauritius, III. Rhodophyceae. Part 2 Gelidiales, Cryptonemiales, Gigartinales. Kongelige Danske Videnskabernes Selskab, Biologiske Meddelelser 19: 1-85.

Børgesen, F. (1947). Remarks on some codiums from the Arabian Sea. In: Sahni, B. (ed.), The Indian Botanical Society, Silver Jubilee Session, Allahabad, M.O.P. Iyengar Commemoration Volume:1-8, 5 Figures. Bangalore.

Børgesen, F. (1952). Some marine algae from Mauritius. Additions to the parts previously published. IV. 
Kongelige Danske Videnskabernes Selskab, Biologiske Meddelelser 18(19): 1-72.

Bory de Saint-Vincent, J. B. (1825). Hydroclathre. Dictionnaire Classique d'Histoire Naturelle 8: 419-420.

Brand, F. (1904). Über die anheftung der Cladophoraceen und über verschiedene polynesische Forme dieser Familie. Beihefte zum Botanischen Centralblatt 18(Abt. 1): 165-193, pls V, VI.

Brown, R. (1810). Prodromus Florae Novae Hollandiae et Insulae Van-Diemen. Taylor, London.

Cho, T.O., Boo, S.M., Hommersand, M.H., Maggs, C.A., McIvor, L.J. and Fredericq, S. (2008). Gayliella gen. nov. in the tribe Ceramieae (Ceramiaceae, Rhodophyta) based on molecular and morphological evidence. Journal of Phycology 44: 721-738.

Clemente y Rubio, S. de R. (1807). Ensayo sobre las variedades de la vid comun que vegetan en Andaluciá. Madrid. xviii + 324 p., 1 plate

Coppejans, E. and Prud'homme van Reine, W.F. (1989). Seaweeds of the Snellius-II Expedition. Chlorophyta: Caulerpales (except Caulerpa and Halimeda). Blumea 34: 119-142.

Coppejans, E. and Prud'homme van Reine, W.F. (1990). A note on Rhipilia nigrescens Coppejans \& Prud'homme van Reine. Blumea 35: 261-262.

Cremades, J. and Pérez-Cirera, J. L. (1990). Nuevas combinaciones de algas bentónicas marinas, como resultado del estudio del herbario de Simón de Rojas Clemente y Rubio (1777-1827). Anales del Jardin Botanico de Madrid 47: 489-492.

Cribb, A.B. (1960). Records of marine algae from southeastern Queensland - V. University of Queensland Papers, Department of Botany 4: 3-31.

Cribb, A.B. (1983). Marine Algae of the Southern Great Barrier Reef. Part 1. Rhodophyta. Australian Coral Reef Society, Brisbane. $173 \mathrm{p}$.

De Clerck, O. (2003). The genus Dictyota in the Indian Ocean. Opera Botanica Belgica 13: 1-205.

De Toni, G. filius (1936). Noterelle di nomenclatura algologica. VII. Primo elenco di Floridee omonime. Brescia 14: 1-8.

Decaisne, M.J. (1841). Plantes de l'Arabie Heureuse, recueillies par M.P.-E. Botta et décrites par M.J. Decaisne. Archives du Muséum d'Histoire Naturelle [Paris] 2: 89-199, pls.V-VII.

Decaisne, M.J. (1842). Mémoire sur les corallines ou polypiers calcifères. Annales des Sciences Naturelles, Botanique ser. 2, 18: 96-128.

Delile, A.R. (1813-1826). Flore d'Egypte. Explication des planches. (1813). Atlas: 62 pls. (1826). In: Description de 1'Egypte ... Histoire naturelle: 145-320. Paris.

Desvaux, N.A. (1809). Observations sur le genre Fluggea, Rich. (Slateria, Desv.). Journal de Botanique (Desvaux) 1(4): 243-246.

Dillwyn, L.W. (1809). British Confervae; or colored Figures and descriptions of the British plants referred by botanists to the genus Conferva. W. Phillips, London. 87 p., pls 69, 100-109.

Doty, M.S. (1963). Gibsmithia hawaiiensis gen. n. et sp. n. Pacific Science 17: 458-465.

Ehrenberg, C.G. (1832). Abhandlungen der Koniglichen Akademie der Wissenschaften in Berlin 1: 429.
Ellis, J. and Solander, D. (1786). The natural history of many curious and uncommon zoophytes, collected from various parts of the globe by the late John Ellis ... Systematically arranged and described by the late Daniel Solander ... B. White \& Son, London. xii + $208 \mathrm{p}$.

Endlicher, S.L. (1843). Mantissa botanica altera. Sistens generum plantarum supplementarum tertium. Fr. Beck, Wein [Vienna]. vi + 111p.

Engler, F. and Prantl, K. (1897). Die natürlichen Pflanzenfamilien. Teil 1, Abt. 2. Wilhelm Engelmann, Leipzig.

Fan, K.C. and Wang, Y.C. (1974). Studies on the marine algae of Hsisha Islands, China. 1. Ganonema gen. nov. Acta Phytotax. Sinica 2: 489-493.

Feldmann, J. (1938). Sur un nouveau genre de Siphonocladacées. Comptes Rendus Hebdomadaires des Séances de l'Académie des Sciences [Paris] 206: 15031504.

Feldmann, J. (1942). Remarques sur les Némastomacées. Bulletin dela Societé Botanique de France 89: 104-113.

Feldmann, J. and Hamel, G. (1934). Observations sur quelques Gélidiacées. Revue Générale de Botanique 46: 528-549.

Feldmann-Mazoyer, G. (1941). Recherches sur les Céramiacées de la Méditerranée occidentale. Imprimerie Minerva, Alger. $510 \mathrm{p}$.

Forsskål, P. (1775). Flora aegyptiaco-arabica: Post mortem auctoris editit Carsten Niebuhr. Copenhagen. xxxvi + $219 \mathrm{p}$.

Foslie, M. (1900). New or critical calcareous algae. Det Kongelige Norske Videnskabers Selskabs Skrifter 1899(5): 1-34.

Foslie, M. (1904). Lithothamnioneae, Melobesieae, Mastophoreae. In A. Weber-van Bosse \& M. Foslie, The Corallinaceae of the Siboga-Expedition. SibogaExpeditie Monographie 61: 10-77, figures. 3-32, pls. I-XIII. Leiden.

Foslie, M. (1906). Algologiske notiser II. Kongelige Norske Videnskabers Selskabs Skrifter 1906(2): 1-28.

Foslie, M. (1907). Algologiske notiser III. Kongelige Norske Videnskabers Selskabs Skrifter 1906(8): 1-34.

Foslie, M. (1909). Algologiske Notiser. VI. Det Kongelige Norske Videnskabers Selskabs Skrifter 1909(2): 1-63.

Garbary, D.J. and Harper, J.T. (1998). A phylogenetic analysis of the Laurencia complex (Rhodomelaceae) of the red algae. Cryptogamie, Algologie 19: 185-200.

Gepp, A. and Gepp, E.S. (1908). Marine algae (Chlorophyceae and Phaeophyceae) and marine phanerogams of the "Sealark" Expedition, collected by J. Stanley Gardiner, M.A., F.R.S., F.L.S. Transactions of the Linnean Society of London, Second Series, Botany 7: 163-188.

Gepp, A. and Gepp, E.S. (1911). The Codiaceae of the Siboga expedition, including a monograph of Flabellarieae and Udoteae. Siboga-Expeditie Monographie 62: 1-150.

Goldberg, N.A. and Kendrick, G.A. (2005). A catalogue of the marine macroalgae found in the western islands of the Recherche Archipelago (Western Australia, Australia), with notes on their distribution in relation to island location, depth, and exposure to wave 
energy. In: Wells, F E, Walker, D I and Kendrick, G A (eds), The Marine Flora and Fauna of Esperance, Western Australia: 25-89. Western Australian Museum, PERTH.

Gomont, M. (1892). Monographie des Oscillariées (Nostocacées homocystées). Annales des Sciences Naturelles, Botanique Series 7, 15: 263-368, Plates 6-14.

Gordon, E.M. (1972). Comparative morphology and taxonomy of the Wrangelieae, Sphondylothamnieae and Spermothamnieae (Ceramiaceae, Rhodophyta). Australian Journal of Botany Suppl. 4: 1-180.

Gray, J.E. (1866). On Anadyomene and Microdictyon, with the description of Three New Allied Genera, Discovered by Menzies in the Gulf of Mexico. Journal of Botany 4: 4-51, 65-72, plate XLIV.

Greville, R.K. (1823). Scottish cryptogamic flora. Vol. 2. Fasc. 18. pls. 86-90. Maclachlan \& Stewart, Edinburgh.

Hartog, C. den (1970). The seagrasses of the World. Verhandelingen der Koninklijke Nederlandse Akademie van Wetenschapen, Afd. Natuurkunde, series 2, 59: 1-275.

Harvey, W.H. (1833). Confervoideae. In: Hooker, W. J. British Flora. Vol. 2, part 1: 259-261, 322-385. Longman, Rees, Orme, Brown, Green \& Longman, London.

Harvey, W.H. (1834). Notice of a collection of algae, communicated to Dr Hooker by the late Mrs. Charles Telfair, from "Cap Malheureux," in the Mauritius; with descriptions of some new and little known species. Journal of Botany [Hooker] 1: 147-157, pls CXXV, CXXVI.

Harvey, W.H. (1853). Nereis boreali-americana ... Part II. Rhodospermeae. Smithsonian Contributions to Knowledge 5: 1-258.

Harvey, W.H. (1855). Some account of the marine botany of the colony of Western Australia. Transactions of the Royal Irish Academy 22(Science): 525-566.

Harvey, W.H. (1860). Characters of new algae, chiefly from Japan and adjacent regions, collected by Charles Wright in the North Pacific exploring expedition under Captain John Rodgers. Proceedings of the American Academy of Arts and Sciences 4: 327-335.

Heydrich, F. (1897). Neue Kalkalgen von Deutsche NeuGuinea (Kaiser Wilhelmsland). Bibliotheca Botanica 1897 (Heft 41): 11 pp., 1 plate

Hillis, L.W. (1959). A revision of the genus Halimeda (Order Siphonales). Publications of the Institute of Marine Science, University of Texas 6: 321-403.

Hillis-Colinvaux, L.W. (1968). New species of Halimeda: a taxonomic reappraisal. Journal of Phycology 4: 20-35.

Hillis-Colinvaux, L. (1980). Ecology and taxonomy of Halimeda: Primary producer of coral reefs. Advances in Marine Biology 17: 1-327.

Hooker, J.D. (1858). The Botany of the Antarctic voyage of H.M. Discovery ships Erebus and Terror, in the years 1839-1843. III. Flora Tasmaniae. Vol. 2. (Monocotyledons). Reeve, London.

Hollenberg, G.J. (1968). An account of the species of Polysiphonia of the central and western tropical Pacific Ocean. I. Oligosiphonia. Pacific Science 22: 56-98.

Howe, M.A. (1920). Algae. In: Britton, N.L. and Millspaugh, C.F. The Bahama Flora, pp. 553-618. New York.

Huisman, J.M. (1996). The red algal genus Coelarthrum
Børgesen (Rhodymeniaceae, Rhodymeniales) in Australian seas, including the description of Chamaebotrys gen. nov. Phycologia 35: 95-112.

Huisman, J.M. (1997). Marine Benthic Algae of the Houtman Abrolhos Islands, Western Australia. In: Wells, F.E. (ed.) The Marine Flora and Fauna of the Houtman Abrolhos Islands, Western Australia: 177-237. Western Australian Museum, PERTH.

Huisman, J.M. (1999). The vegetative and reproductive morphology of Nemastoma damaecorne (Gigartinales, Rhodophyta) from western Australia. Australian Systematic Botany 11: 721-728

Huisman, J.M. (2000). Marine Plants of Australia. University of Western Australia Press. ix + 300 pp.

Huisman, J.M. (2002). The type and Australian species of the red algal genera Liagora and Ganonema (Liagoraceae, Nemaliales). Australian Systematic Botany 15: 773-838.

Huisman, J.M. (2006). Algae of Australia: Nemaliales. ABRS, Canberra. viii +153 pp.

Huisman, J.M. and Borowitzka, M.A. (1990). A revision of the Australian species of Galaxaura (Rhodophyta, Nemaliales), with a description of Tricleocarpa gen. nov. Phycologia 29: 150-172.

Huisman, J.M. and Borowitzka, M.A. (2003). Marine benthic flora of the Dampier Archipelago, Western Australia. In Wells, F.E., Walker, D.I. and Jones, D.S. (eds), The Marine Flora and Fauna of Dampier, Western Australia: 291-344. Western Australian Museum. PERTH.

Huisman, J.M. and Millar, A.J.K. (1996). Asteromenia (Rhodymeniaceae, Rhodymeniales), a new red algal genus based on Fauchea peltata. Journal of Phycology 32: 138-145.

Huisman, J.M., Abbott, I.A. and Smith, C.M. (2007). Hawaiian Reef Plants. University of Hawaii Sea Grant, Honolulu. 264 pp.

Huisman, J.M., Cowan, R.A. and Entwisle, T.J. (1998). Biodiversity of Australian marine macroalgae - a progress report. Botanica Marina 41: 89-93.

Huisman, J.M., Harper, J.T. and Saunders, G.W. (2004). Phylogenetic study of the Nemaliales (Rhodophyta) based on large-subunit ribosomal DNA sequences supports segregation of the Scinaiaceae fam. nov. and resurrection of Dichotomaria Lamarck. Phycological Research 52: 224-234.

Huisman, J.M., Phillips, J. and Parker, C.M. (2006). Marine Plants of the PERTH Region. Department of Environment and Conservation, PERTH. 72 p.

Huisman, J.M., Saunders G.W. and Sherwood, A.R. (2006a). Titanophycus. Algae of Australia: Nemaliales 81-82.

Huisman, J.M., Saunders G.W. and Sherwood, A.R. (2006b). Recognition of Titanophycus, a new genus based on Liagora valida Harvey (Liagoraceae, Nemaliales) Algae of Australia: Nemaliales 116-119.

Huisman, J.M., Sherwood A.R. and Abbott, I.A. (2003). Morphology, reproduction, and the 18s rRNA gene sequence of Pihiella liagoraciphila gen. et sp. nov., (Rhodophyta), the so-called 'monosporangial discs' associated with members of the Liagoraceae (Rhodophyta), and proposal of the Pihiellales ord. 
nov. Journal of Phycology 39: 978-987.

Itono H. (1969). The genus Antithamnion (Ceramiaceae) in southern Japan and adjacent waters-I. Memoirs of the Faculty of Fisheries, Kagoshima University 18: 29-45.

Itono, H. and Tanaka, T. (1973). Balliella, a new genus of Ceramiaceae (Rhodophyta). Botanical Magazine Tokyo 86: $241-252$.

Jones, R. and Kraft, G. T. (1984). The genus Codium (Codiales, Chlorophyta) at Lord Howe Island, (N.S.W). Brunonia 7: 253-276.

Kawaguchi, S., Kato, A., Masuda, M., Kogame K., and Phang, S. M. (2002). Taxonomic notes on marine algae from Malaysia. VII. Five species of Rhodophyceae, with the description of Lomentaria gracillima sp. nov. Botanica Marina 45: 536-547.

Keats, D.W. and Chamberlain, Y.M. (1994). Three species of Hydrolithon (Rhodophyta, Corallinaceae): Hydrolithon onkodes (Heydrich) Penrose and Woelkerling, Hydrolithon superficiale sp. nov., and $H$. samoënse (Foslie) comb. nov. from South Africa. South African Journal of Botany 60: 8-21.

Keats, D.W., Steneck, R.S., Townsend, R.A. and Borowitzka, M.A. (1996). Lithothamnion prolifer Foslie: a common non-geniculate coralline alga (Rhodophyta; Corallinaceae) from the tropical and subtropical IndoPacific. Botanica Marina 39: 187-200.

Kim, M.-S. \& Lee, I.K. (1999). Neosiphonia flavimarina gen. et sp. nov. with a taxonomic reassessment of the genus Polysiphonia (Rhodomelaceae, Rhodophyta). Phycological Research 47: 271-281.

König, C (1805). Addition to M. Carrolini's treatise on Zostera oceanica L. In: Ann. Bot. 2: 91-99. König \& Sims, London.

Koster, J.T. (1937). Algues marines des îlots Itu-Aba, Sand Caye et Nam-Yit, situés à l'ouest de l'île Palawan (Philippines). Blumea Suppl. 1: 219-228, Plate XV.

Kraft, G.T. (1984). The red algal genus Predaea (Nemastomataceae, Gigartinales) in Australia. Phycologia 23: 3-20.

Kraft, G.T. (1986a). The green algal genera Rhipiliopsis A. \& E.S. Gepp and Rhipiella gen. nov. (Udoteaceae, Bryopsidales) in Australia and the Philippines. Phycologia 25: 47-72.

Kraft, G.T. (1986b). The genus Gibsmithia (Dumontiaceae, Rhodophyta) in Australia. Phycologia 25: 423-447.

Kraft, G.T. (1988). Seirospora orientalis (Callithamnieae, Ceramiales), a new red algal species from the southern Great Barrier Reef. Japanese Journal of Phycology 36: 1-11.

Kraft, G.T. (2000). Marine and estuarine benthic green algae (Chlorophyta) of Lord Howe lsland, south western Pacific. Australian Systematic Botany 13: 509-648.

Kraft, G.T. (2007). Algae of Australia: Marine Benthic Algae of Lord Howe Island and the Southern Great Barrier Reef, 1: Green Algae. ABRS, Canberra; CSIRO Publishing, Melbourne. vi +347 pp.

Kraft, G.T. and Abbott, I.A. (1971. Predaea weldii, a new species of Rhodophyta from Hawaii, with an evaluation of the genus. Journal of Phycology 7: 194202.

Kraft, G.T. and Wynne, M.J. (1996). Delineation of the genera Struvea Sonder and Phyllodictyon J.E. Gray (Cladophorales, Chlorophyta). Phycological Research 44: 129-143.

Kraft, G.T., Liao, L.M., Millar, A.J.K., Coppejans, E.G.G., Hommersand, M.H. and Freshwater, D.W. (1999). Marine benthic red algae (Rhodophyta) from Bulusan, Sorsogon Province, Southern Luzon, Philippines. The Philippine Scientist 36: 1-50.

Kützing, F.T. (1841). Ueber Ceramium Ag. Linnaea 15: 727-746.

Kützing, F.T. (1843). Phycologia generalis oder Anatomie, Physiologie und Systemkunde der Tange..... Brockhaus, Leipzig. xxxii +458 p.

Kützing, F.T. (1849). Species algarum. Brockhaus, Leipzig. $\mathrm{vi}+922 \mathrm{p}$.

Kützing, F.T. (1856). Tabulae phycologicae. Vol. 6. Nordhausen, Köhne. iv + 35 p., 100 pls.

Kützing, F.T. (1858). Tabulae phycologicae. Vol. 8. Nordhausen, Köhne. ii + 48 p., 100 pls.

Kützing, F.T. (1862). Tabulae phycologicae. Vol. 12. Nordhausen, Köhne. iv + 30 p., 100 pls.

Kützing, F.T. (1863). Tabulae phycologicae. Vol. 13. Nordhausen, Köhne. iii +31 p., 100 pls.

Kützing, F.T. (1868). Tabulae phycologicae. Vol. 18. Nordhausen, Köhne. iii + 35 p., 100 pls.

Lagerheim, G. (1887). Note sur l'Uronema, nouveau genre des algues d'eau douce. Malpigia 1: 517-523.

Lamarck, J.B.A.P. de (1816). Histoire naturelle des animaux sans vertèbres. Vol. 2. Paris. 568 pp.

Lamouroux, J.V.F. (1809a). Exposition des caractères au genre Dictyota (1) et tableau des espèces qu'il renferme. Journal de Botanique [Desvaux] 2: 38-44.

Lamouroux, J.V.F. (1809b). Observations sur la physiologie des algues marines, et description de cinq nouveaux genres de cette famille. Nouveau Bulletin des Sciences, par la Société Philomathique de Paris. 1: 330-333.

Lamouroux, J.V.F. (1812). Sur la classification des Polypiers coralligènes non entièrement pierreux. Société Philomatique de Paris, Nouveau Bulletin des Sciences 3: 181-188.

Lamouroux, J.V.F. (1813). Essai sur les genres de la famille des thalassiophytes non articulees. Annales de Muséum National d'Histoire Naturelle [Paris] 20: 21-47, 115-139, 267-293, pls 7-13.

Lamouroux, J.V.F. (1816). Histoire Des Polypiers Coralligènes Flexibles, Vulgairement Nommés Zoophytes... F. Poisson, Caen. lxxxiv + 560 pp.

Lamouroux, J.V.F. (1825). Turbinaria. Dictionnaire Classique d'Histoire Naturelle. 7: 71.

Leliaert, F. \& Coppejans, E. (2003). The marine species of Cladophora (Chlorophyta) from the South African east coast. Nova Hedwigia 76(1-2): 45-82.

Leliaert, F. and Coppejans, E. (2006). A revision of Cladophoropsis Borgesen (Siphonocladales, Chlorophyta). Phycologia 49: 657-679.

Leliaert, F. and Coppejans, E. (2007). Systematics of two deep-water species from the Indo-West Pacific: Struvea gardineri A. Gepp \& E. Gepp and Phyllodictyon orientale (A.Gepp \& E.Gepp) Kraft \& M.J. Wynne (Siphonocladales, Chlorophyta). Botanical Journal of the 
Linnean Society 153: 115-132.

Leliaert, F., Huisman, J.M. and Coppejans, E. (2007). Phylogenetic position of Boodlea vanbosseae (Siphonocladales, Chlorophyta). Cryptogamie, Algologie 28: 337-351.

Leliaert, F., De Clerck, O., Verbruggen, H., Boedeker, C. \& Coppejans, E. (2007). Molecular phylogeny of the Siphonocladales (Chlorophyta: Cladophorophyceae). Molecular Phylogenetics and Evolution 44: 1237-1256.

Leliaert, F., Rousseau, F., Reviers, B. de and Coppejans, E. (2003). Phylogeny of the Cladophorophyceae (Chlorophyta) inferred from partial LSU rRNA gene sequences: is the recognition of a separate order Siphonocladales justified? European Journal of Phycology 38: 233-246.

Leliaert F., Wysor B., Verbruggen H., Vlaeminck C. and De Clerck O. (2008).Phyllodictyon robustum (Setchell et Gardner) comb. nov. (Siphonocladales, Chlorophyta), a morphologically variable species from the tropical Pacific coast of America. Cryptogamie Algologie 29: 217-233.

Linnaeus, C. (1753). Species plantarum... Vol. 2.: 561-1200. Impensis Laurentii Salvii, Holmiae [Stockholm].

Linnaeus, C. (1758). Systema naturae... 10th ed. Vol. 1. Salvii, Holmiae [Stockholm]. iv +823 p.

Littler, D.S. and Littler, M.M. (2000). Caribbean Reef Plants. OffShore Graphics Inc., Washington. 542 p.

Littler, D.S. and Littler, M.M. (2003). South Pacific Reef Plants. A diver's guide to the plant life of the South Pacific Coral Reefs. OffShore Graphics, Inc., Washington. 331 p.

Lyle, L. (1922). Antithamnionella, a new genus of algae. Journal of Botany 60: 346-350.

Lyngbye, H. C. (1819). Tentamen Hydrophytologie Danicae. Hafniae [Copenhagen]. xxxii +248 p.

Martens, G.V. (1866). Die Preussische Expedition nach OstAsien. K. Geheime, Berlin. 152 p.

Martens, G. von and Hering, C. (1836). Amansia jungermannioides. Flora 19: 481-487.

Mazoyer, G. (1938). Les Céramiacées de l'Afrique du Nord. Bulletin de la Société de l'Histoire naturelle de l'Afrique du Nord 29: 317-331.

McCarthy, P.M. and Orchard, A.E. (eds.) (2007). Algae of Australia: Introduction. Australian Biological Resources Study, Canberra; CSIRO Publishing, Melbourne. xvi $+727 \mathrm{p}$.

Meneghini, G. (1840). "Lettera del Prof. Giuseppe Meneghini al Dottore Iacob Corinaldi a Pisa. (Pisa.) [Folded sheet without pagination; Bibliothèque Thuret-Bornet, Muséum National d'Histoire Naturelle, Paris.]

Millar, A.J.K. (1990). Marine red algae of the Coffs Harbour region, northern New South Wales. Australian Systematic Botany 3: 293-593.

Millar A.J.K., De Clerck, O., Coppejans E. and Liao, L.M. (1999). Annotated and illustrated survey of the marine macroalgae from Motupore Island and vicinity (Port Moresby area, Papua New Guinea). III. Rhodophyta. Australian Systematic Botany 12: 549-591.

Millar, A.J.K. and Kraft, G.T. (2001). Monograph of the green macroalgal genus Rhipilia (Udoteaceae, Halimedales), with a description of $R$. crassa sp. nov. from Australia and the Philippines. Phycologia 40: 21-34.

Montagne, C. (1837). Centurie de plantes cellulaires exotiques nouvelles. Annales des Sciences Naturelles, Botanique, ser. 2 8: 345-370.

Montagne, C. (1839-1841). Plantae cellulares. In: BarkerWebb, P. and Berthelot, S. Histoire naturelle des Iles Canaries. Vol. 3, part 2, sect. 4, pp 1-16 (1839), 17-160 (1840), 161-208, I-XV (1841). Paris.

Montagne, C. (1842). Prodromus generum specierumque phycearum novarum, in itinere ad polum antarticum. . . collectarum. Paris. 16 p.

Montagne, C. (1846). Ordo I. Phyceae Fries. In: Durieu de Maisonneuve, M.C. Exploration scientifique de l'Algérie pendant les années 1840, 1841, 1842.... Sciences physiques. Botanique. Cryptogamie.: 1-197. Paris.

Montagne, J.F.C. (1857). Huitième centurie de plantes cellulaires nouvelles, tant indigènes qu'exotiques. Décades IV et V. Annales des Sciences Naturelles, Botanique, Serie 4 7: 134-153.

Murray, G. and De Toni, G. B. (1889). On a new genus of Chlorophyceae, Boodlea. Journal of the Linnean Society of Botany 25: 243-245.

Nägeli, C. (1846). Herposiphonia. Zeitschr. Wiss. Bot. 1: 238-256.

Nägeli, C. (1847). Die neuern Algensysteme und Versuch zur Begründung eines eigenen Systems der Algen und Florideen. Neue Denkschriften der Allg. Schweizerischen Gesellschaft für die Gesammten Naturwissenschaften 9(2): 275.

Nägeli, C. (1862). Beiträge zue morphologie und systematik der Ceramiaceae. Sitzungsberichte der Königlichen Bayerischen Akademie der Wissenschaften zu München (1861)2: 297-415, 1pl.

Norris, R.E. (1993). Taxonomic studies on Ceramieae (Ceramiales, Rhodophyta) with predominantly basipetal growth of corticating filaments. Botanica Marina 36: 389-398.

Okamura, K. (1916). List of marine algae collected in Caroline and Mariana Islands, 1915. Botanical Magazine, Tokyo 30: 1-14, 9 Figures, Plate I.

Oliveira, E. C. de (1977). Algas marinhas bentônicas do Brasil. Universidade de São Paulo, Instituto de Biociências, São Paulo, Brazil. [IV +] 407 pp.

Oliveira, E., Österlund, K. and Mtolera, M.S.P. (2005). Marine Plants of Tanzania. A field guide to the seaweeds and seagrasses. Botany Department, Stockholm University, Stockholm. 267 p.

Olsen-Stojkovich, J. (1985). A systematic study of the genus Avrainvillea Decaisne (Chlorophyta, Udoteaceae). Nova Hedwigia 41: 1-68.

Ostenfeld, C.F. (1902). Hydrocharitaceae, Lemnaceae, Pontederiaceae, Potamogetonaceae, Gentianaceae (Limnanthemum), Nymphaceae. Botanisk Tidsskrift 24: 260-263.

Penrose, D. (1996). Genus Hydrolithon (Foslie) Foslie 1909: 55. In: Womersley, H.B.S. The marine benthic flora of southern Australia. Rhodophyta. Part IIIB, Gracilariales, Rhodymeniales, Corallinales and Bonnemaisoniales.: 255266. Australian Biological Resources Study, Canberra.

Penrose, D. and Chamberlain, Y.M. (1993). Hydrolithon farinosa (Lamouroux) comb. nov.: implications 
for generic concepts in the Mastophoroideae (Corallinaceae, Rhodophyta). Phycologia 32: 295-303.

Penrose, D. and Woelkerling, W.J. (1992). A reappraisal of Hydrolithon and its relationships to Spongites (Corallinaceae, Rhodophyta). Phycologia 31: 81-88.

Philippi, R.A. (1837). Beweis, dass die Nulliporen Pflanzen sind. Archiv für Naturgeschichte 3: 387-393, plate 9, figures. 2-6.

Phillips, J.A. (2000), Systematics of the Australian species of Dictyopteris (Dictyotales, Phaeophyceae). Australian Systematic Botany 13: 283-324.

Phillips, R.C. and Meñez, E.G. (1988). Seagrasses. Smithsonian Contributions to Marine Science Number 34. 104 p.

Pilger, R. (1911). Die Meeresalgen von Kamerun. Nach der Sammlung von C. Ledermann. In: Engler, A. Beiträge zur Flora von Africa xxxix. Botanische Jahrbücher für Systematik, Pflanzengeschichte un Pflanzengeographie 46: 294-323

Price, I.R. and Kraft, G.T. (1991). Reproductive development and classification of the red algal genus Ceratodictyon (Rhodymeniales, Rhodophyta). Phycologia 30: 106-116.

Price, I.R. and Scott, F.J. (1992). The Turf Algal Flora of the Great Barrier Reef Part 1. Rhodophyta. James Cook University of North Queensland, Townsville. 266 p.

Reinbold, T. (1905). Einige neue Chlorophyceen aus dem Ind. Ocean (Niederl. Indien), gesammelt von A. Weber-van Bosse. Nuova Notarisia 16: 145-149.

Reinke, J. (1889). Algenflora der westlichen Ostsee deutschen Antheils. Eine systematischpflanzengeographische Studie. Bericht der Kommission zur Wissenschaftlichen Untersuchung der Deutschen Meere in Kiel 6: [i-] iii-xi, 1-101.

Richards, H.M. (1901). Ceramothamnion codii, a new rhodophyceous alga. Bulletin of the Torrey Botanical Club 28: 257-265, Plates 21, 22.

Ringeltaube, P. and Harvey, A. (2000). Non-geniculate coralline algae (Corallinales, Rhodophyta) on the Heron Reef, Great Barrier Reef (Australia). Botanica Marina 43: 431-454.

Robertson, E.L. (1984). Seagrasses. In: Womersley, H.B.S. The Marine Benthic Flora of Southern Australia. Part 1. : 57-122. Government Printer, South Australia.

Roth, A.W. (1797). Catalecta botanica ... I.G. Mülleriano, Leipzig. pp. viii +244 p.

Santelices, B. (1976). Taxonomic and nomenclatural notes of some Gelidiales (Rhodophyta). Phycologia 15: 165-173.

Santelices, B. and Hommersand, M.H. (1997). Pterocladiella, a new genus in the Gelidiaceae (Gelidiales, Rhodophyta). Phycologia 36: 114-119.

Saunders, G.W., Lane, C.E., Schneider, C.W. and Kraft, G.T. (2006). Unraveling the Asteromenia peltata species complex with clarification of the genera Halichrysis and Drouetia (Rhodymeniaceae, Rhodophyta). Canadian Journal of Botany 84: 1581-1607, 83 Figures, 3 tables.

Schils, T. and Coppejans, E. (2002). Gelatinous red algae of the Arabian Sea, including Platoma heteromorphum sp. nov. (Gigartinales, Rhodophyta). Phycologia 41: 254-267.
Schmitz, C.J.F. (1894). Neue Japanische florideen von K. Okamura. Hedwigia Bd 33: 190-201, Plate X. Dresden. Schmitz, C.J.F. (1895). Marine florideen von Deutsch-Ostafrica. Botanische Jahrbücher für Systematik, Pflanzengeschichte und Pflanzengeographie 21: 137-177.

Setchell, W.A. (1925). Notes on Microdictyon. University of California Publications in Botany 13: 101-107.

Setchell, W.A. (1926). Tahitian algae collected by W.A. Setchell, C.B. Setchell, and H.E. Parks. University of California Publications in Botany 12: 61-142, including pls. 7-22.

Setchell, W.A. (1929). The genus Microdictyon. University of California Publications in Botany 14: 453-588.

Shevejko, S.V. (1982). Novaya krasnaya izvestkovaya vodorosl'. [A new red calcareous alga.] In Biologiya korallovykh rifov. Soobshchestva priavstralijskikh vod. [Biology of coral reefs. Associations in Australian near-shore waters.] : 26-28 + 2 Figures. [Russian.] Akademiya Nauk SSSR, Dal'nevostochnyj Nauchnyj Tsentr, Institut Biologii Morya, Vladivostok.

Silva, P.C., Basson, P.W. and Moe, R.L. (1996). Catalogue of benthic marine algae of the Indian Ocean. University of California Publications in Botany 79. 1279 pp.

Silva, P.C., Meñez, E.G. and Moe, R.L. (1987). Catalog of the benthic marine algae of the Philippines. Smithsonian Contributions to Marine Sciences 27: iv + $179 \mathrm{p}$.

Skewes, T.D., Gordon, S.R., McLeod, I.R., Taranto, T.J., Dennis, D.M., Jacobs, D.R., Pitcher, C.R., Haywood, M., Smith, G.P., Poiner, I.R., Milton, D., Griffin, D, and Hunter, C. (1999). Survey and Stock Size Estimates of the Shallow Reef $(0-15 \mathrm{~m})$ and Shoal Area (15-50 m Deep) Marine Resources and Habitat Mapping within the Timor Sea. Volume 2. Habitat Mapping and Coral Dieback, Department of the Environment and Heritage, Canberra. Report available at: http://www.deh.gov. $\mathrm{au} /$ coasts/mpa/ashmore/volume-2/

South, G.R. and Skelton, P.A. (2000). A review of Ceramium (Rhodophyceae, Ceramiales) from Fiji and Samoa, South Pacific. Micronesica 33: 45-98.

Stackhouse, J. (1797). Nereis Britannica...Fasc. 2. S. Hazard; J. White, Bathoniae [Bath] \& Londini [London]. pp. ixxxiv, 31-70 p., pls IX-XIII.

Taylor, W.R. (1950). Plants of Bikini and other northern Marshall Islands. University of Michigan Press, Ann Arbor. xv + 227 p., 79 pls.

Taylor, W.R. (1960). Marine Algae of the Eastern Tropical and Subtropical Coasts of the Americas. University of Michigan Press, Ann Arbor. xi + 870 p.

Taylor, W.R. (1966). Records of Asian and western Pacific marine algae, particularly algae from Indonesia and the Philippines. Pacific Science 20: 342-359.

Thouars, L.M.A. Du Petit- (1806). Genera Nova Madagascariensia secundum methodum Jussiaeanam disposita. Paris.

Tilden, J.E. (1909). American algae. Cent. 7 (Exsiccata). Vol. Cent. 7: pp. 601-650. Minneapolis.

Trevisan, V.B.A. (1845). Nomenclator algarum, ou collection des noms imposées aux plantes de la famille des algues. Vol. 1. Padoue [Padua]. 80 p.

Turner, D. (1807-1808). Fuci ... Vol. 1. London. [iii+] 164 
[+2] p., pls 1-71.

Unger, F. (1858). Beiträge zur näheren Kenntniss des Leithakalkes, namentlich der vegetabilischen Einschlüsse und der Bildungsgeschichte desselben. Denkschriften der Kaiserlichen Akademie der Wissenschaften [Wein], Mathematischnaturwissenschaftliche Klasse 14: 13-35.

Vahl, M. (1802). Endeel kryptogamiske planter fra St.Croix. Skrifter af Naturhistorie-Selskabet [Kiobenhaven] 5: 29-47.

Van den Hoek, C. (1963). Revision of the European species of Cladophora. Proefschrift...Rijksuniversiteit te Leiden. E. J. Brill, Leiden. $x i+248$ p.

Van den Heede, C. and Coppejans, E. (1996). The genus Codium (Chlorophyta, Codiales) from Kenya, Tanzania (Zanzibar) and the Seychelles. Nova Hedwigia 62: 389-417.

Verheij, E. and Prud'homme van Reine, W.F. (1993). Seaweeds of the Spermonde Archipelago, SW Sulawesi, Indonesia. Blumea 37: 385-510.

Verheij, E. and Woelkerling, W.J. (1992). The typification of nongeniculate Corallinales (Rhodophyta) involving Siboga Expedition collections. Blumea 36: 273-291.

Vickers, A. (1905). Liste des algues marines de la Barbade. Annales des Sciences Naturelles, Botanique 1: 45-66.

Walker, D.I. (1996). Seagrasses and Macroalgae. In: Walker, D.I., Wells, F.E. and Hanley, J.R. (eds), Marine Biological Survey of the eastern Kimberley, Western Australia: 36-38, tables 5.2a-c. University of Western Australia, Western Australian Museum, Museum and Art Gallery of the Northern Territory.

Walker, D.I. and Prince, R.I.T. (1987). Distribution and biogeography of seagrass species on the northwest coast of Australia. Aquatic Botany 29: 19-32.

Walker, D.I., Wells, F.E. and Hanley, J.R. (eds) (1996). Marine Biological Survey of the eastern Kimberley, Western Australia. University of Western Australia, Western Australian Museum, Museum and Art Gallery of the Northern Territory. ii +84 pp.

Weber-van Bosse, A. (1905). Note sur le genre Dictyosphaeria Dec. Nuova Notarisia 16: 142-144.

Weber-van Bosse, A. (1913). Liste des algues du Siboga 1. Myxophyceae, Chlorophyceae, Phaeophyceae avec le concours de M.Th. Reinbold. Siboga-Expeditie Monographie 59a: 1-186.

Weber-van Bosse, A. (1928). Liste des algues du Siboga. IV: Rhodophyceae. Troisième partie. Gigartinales et Rhodymeniales et tableau de la distribution des Chlorophycées, Phaeophycées et Rhodophycées de 1'Archipel Malaisien. Siboga-Expeditie Monographie 59d: 393-533, pls XI-XVI.

Weber-van Bosse, A. and Foslie, M. (1904). The Corallinaceae of the Siboga-Expedition. Siboga Expeditie Monographie 61: 1-110, 32 Figures, XVI plates.

Woelkerling, W.J. (1988). The coralline red algae: an analysis of the genera and subfamilies of nongeniculate Corallinaceae. British Museum (Natural History), London and Oxford University Press, Oxford. xi + $268 \mathrm{p}$.

Womersley, H.B.S. (1978). Southern Australian species of Ceramium Roth (Rhodophyta). Australian Journal of Marine and Freshwater Research 29: 205-257.

Womersley, H.B.S. (1984). The Marine Benthic Flora of Southern Australia. Part 1. Government Printer, South Australia. 329 p.

Womersley, H.B.S. (1987). The Marine Benthic Flora of Southern Australia. Part II. Government Printer, South Australia. $484 \mathrm{p}$.

Womersley, H.B.S. (1998). The Marine Benthic Flora of Southern Australia. Part IIIC. Australian Biological Resources Study, Canberra \& State Herbarium of South Australia, Adelaide. 535 p.

Womersley, H.B.S. and Cartledge, S.A. (1975). The southern Australian species of Spyridia (Ceramiaceae: Rhodophyta). Transactions of the Royal Society of South Australia 99: 221-233.

Wulfen, F.X. (1803). Cryptogama aquatica. Archiv für Botanik 3: 1-64.

Wynne, M.J. (1985). Concerning the names Scagelia corallina and Heterosiphonia wurdemannii (Ceramiales, Rhodophyta). Cryptogamie, Algologie 6: 81-90.

Yamada, Y. (1941). [On the species of Halimeda from Micronesia]. Kagaku Nanyõ 4: 108-121.

Yamada, Y. (1944). A list of the marine algae from the atoll of Ant. Scientific Papers of the Institute of Algological Research, Faculty of Science, Hokkaido Imperial University 3: 31-45.

Zanardini, G. (1851). Algae novae vel minus cognitae in mari Rubro a Portiero collectae. Flora 34: 33-38.

Zanardini, G. (1878). Phyceae papuanae novae vel minus cognitae a cl. O. Beccari in itinere ad Novam Guineam annis 1872-75 collectae. Nuovo Giornale Botanico Italiano 10: 34-40. 
